In cooperation with the city of Palmdale, California

\title{
Feasibility and Potential Effects of the Proposed Amargosa Creek Recharge Project, Palmdale, California
}

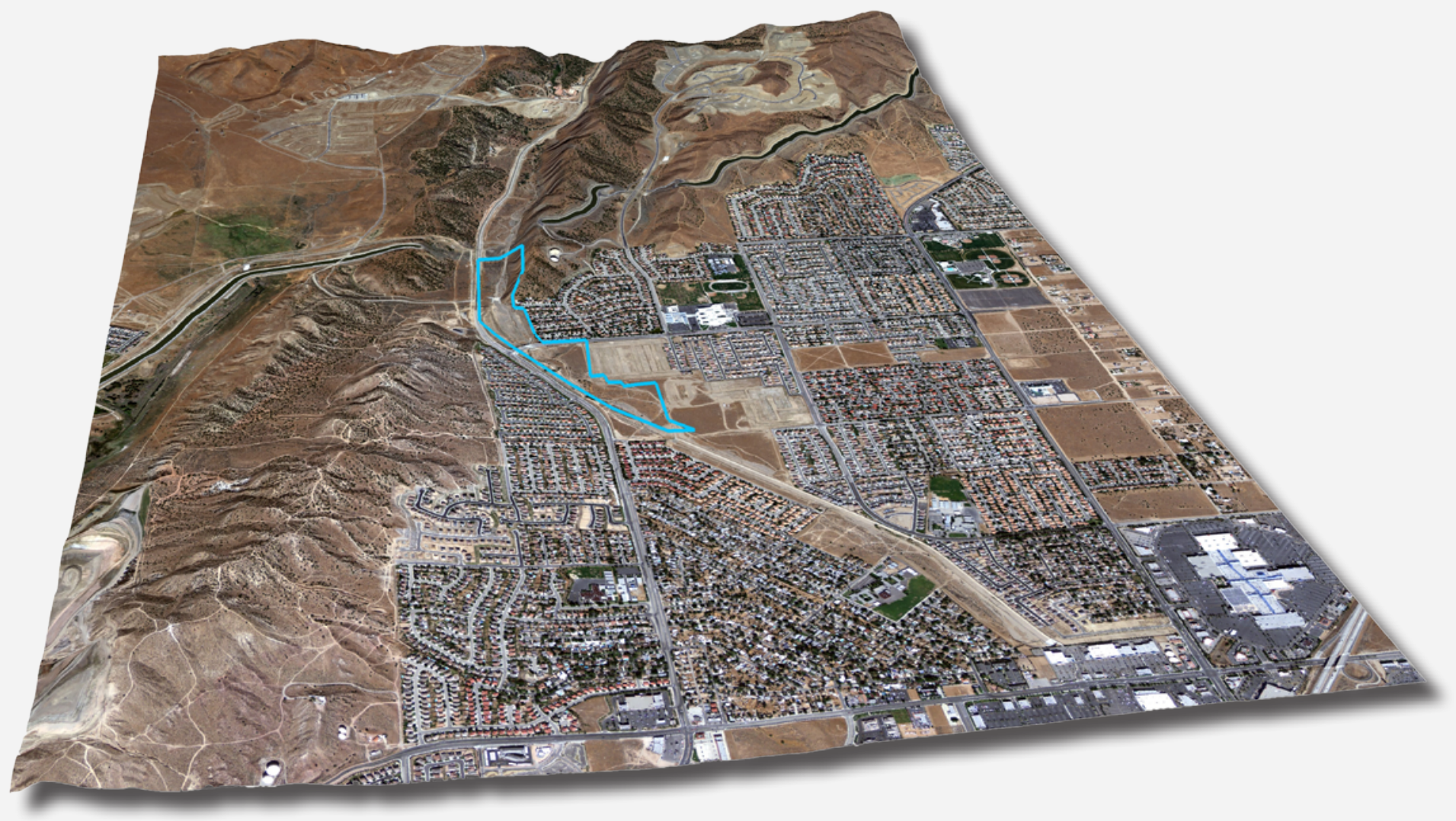

Scientific Investigations Report 2015-5054 
Cover. Three-dimensional image created using U.S. Geological Survey National Elevation Dataset, U.S. Department of Agriculture National Agriculture Imagery Program (NAIP 2010) and ESRI ArcScene. 


\section{Feasibility and Potential Effects of the Proposed Amargosa Creek Recharge Project, Palmdale, California}

By Allen H. Christensen, Adam J. Siade, Peter Martin, Victoria E. Langeheim, Rufus D. Catchings, and Matthew K. Burgess

In cooperation with the city of Palmdale, California

Scientific Investigations Report 2015-5054 


\section{U.S. Department of the Interior \\ SALLY JEWELL, Secretary}

\section{U.S. Geological Survey \\ Suzette M. Kimball, Acting Director}

\section{U.S. Geological Survey, Reston, Virginia: 2015}

For more information on the USGS - the Federal source for science about the Earth, its natural and living resources, natural hazards, and the environment—visit http://www.usgs.gov or call 1-888-ASK-USGS.

For an overview of USGS information products, including maps, imagery, and publications, visit http://www.usgs.gov/pubprod/.

Any use of trade, firm, or product names is for descriptive purposes only and does not imply endorsement by the U.S. Government.

Although this information product, for the most part, is in the public domain, it also may contain copyrighted materials as noted in the text. Permission to reproduce copyrighted items must be secured from the copyright owner.

Suggested citation:

Christensen, A.H., Siade, A.J., Martin, Peter, Langeheim, V.E., Catchings, R.D., and Burgess, M.K., 2015, Feasibility and potential effects of the proposed Amargosa Creek recharge project, Palmdale, California: U.S. Geological Survey Scientific Investigations Report 2015-5054, 48 p., http://dx.doi.org/10.3133/SIR20155054. 


\section{Contents}

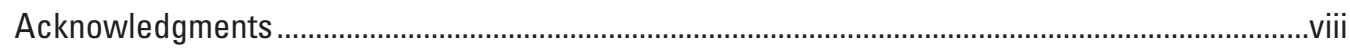

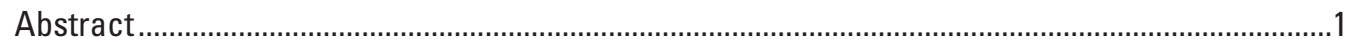

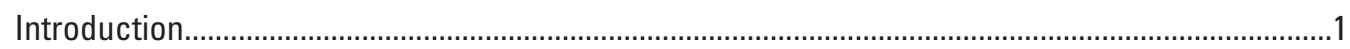

Purpose and Scope .....................................................................................................

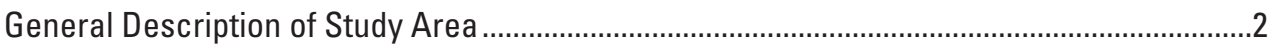

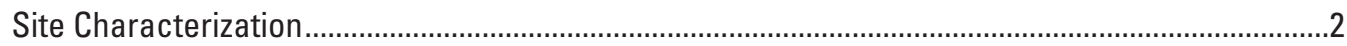

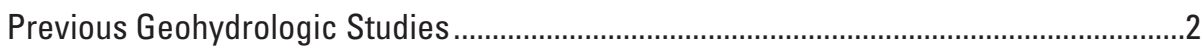

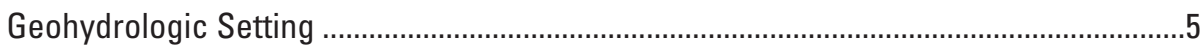

Monitoring Well Construction................................................................................................

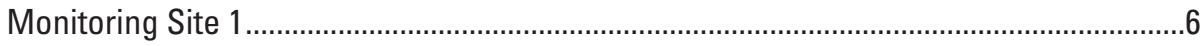

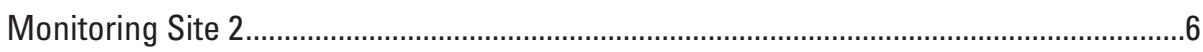

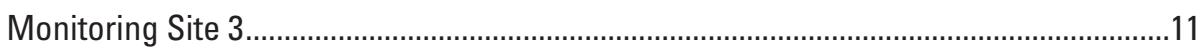

Water-Level Data Collected from Monitoring Wells ......................................................12

Water-Quality Data Collected from Monitoring Wells.......................................................12

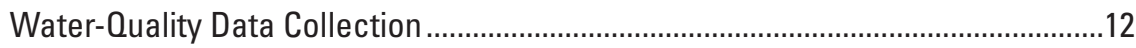

Physical and Chemical Characteristics .................................................................12

Source and Age of Groundwater .....................................................................

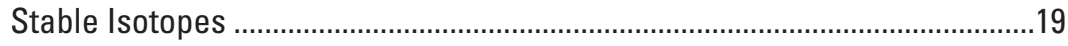

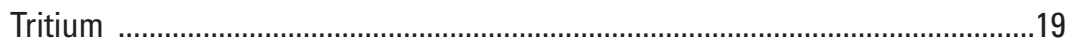

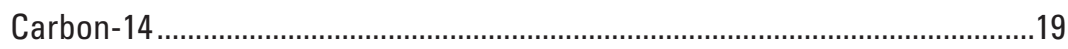

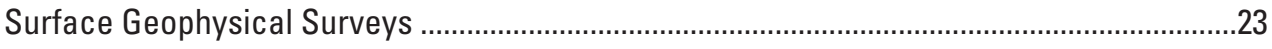

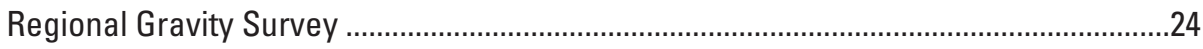

Gravity Survey and Reduction Data Sets..............................................................24

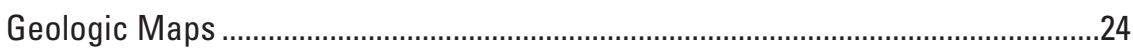

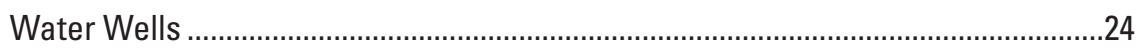

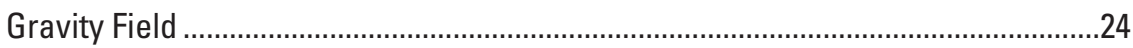

Computation Method for Modeling Thickness of Valley-Fill Deposits....................26

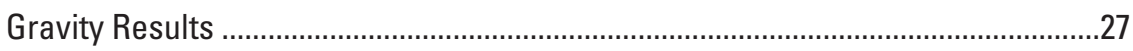

Seismic Refraction and Reflection, and Direct- Current Resistivity Surveys..................27

Seismic Refraction and Reflection Survey ..........................................................27

Seismic Data Acquisition and Processing ..........................................................30

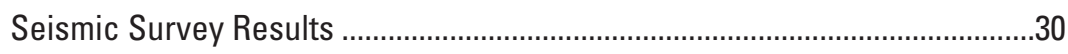

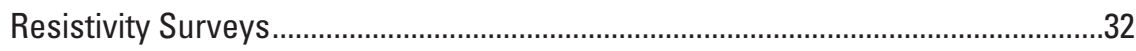

Resistivity Data Acquisition ................................................................................32

Resistivity Data Processing ............................................................................32

Resistivity Survey Results .............................................................................33

Summary of Geophysical Surveys ……......................................................................

Geohydrologic Structure beneath the ACRP and Vicinity.....................................................3

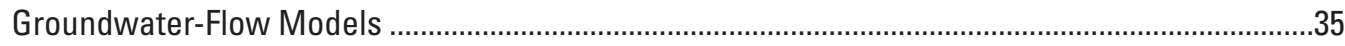

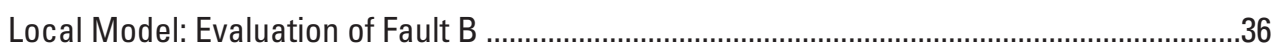

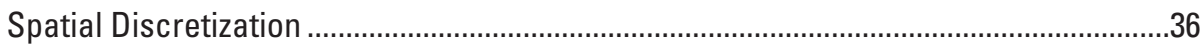

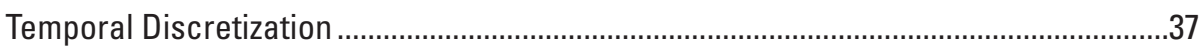




\section{Contents-Continued}

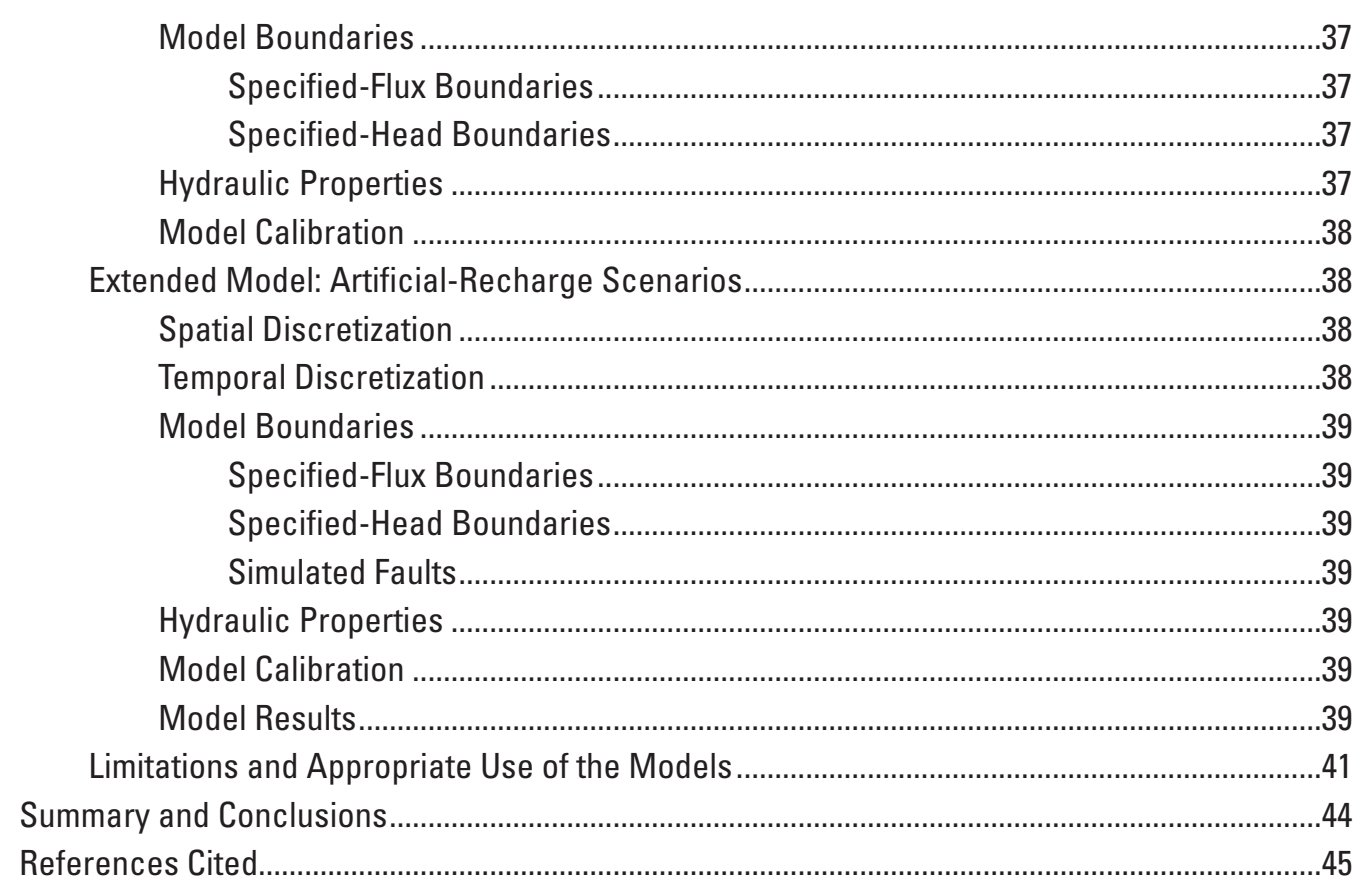

\section{Figures}

1. Map showing study area and Leona Valley surface-water drainage basin (Amargosa Creek drainage basin), Antelope Valley, California ......................................... 3

2. Map showing location of study area boundary, Antelope Valley, California......................

3. Generalized geologic section showing relation of lacustrine deposits to aquifers in the Antelope Valley groundwater basin, Antelope Valley, California ................................5

4. Map showing locations of monitoring sites 1, 2, and 3, near Palmdale, California ...........7

5. Schematic showing geophysical logs and well construction for monitoring sites near Palmdale, California: site 1 (6N/12W-29B1)

6. Schematic showing geophysical logs and well construction for monitoring sites near Palmdale, California: site 2 (6N/12W-21G1).

7. Schematic showing geophysical logs and well construction for monitoring site 3 (6N/12W-21G001-4), near Palmdale, California.

8. Map showing hydraulic head at selected wells, Antelope Valley, California, 2009 ........13

9. Graph showing stable isotope data for samples collected from monitoring sites 1 , 2 , and 3 and the vicinity of Palmdale, California, 2009-13..........................................22

10. Map showing location of geophysical surveys, Antelope Valley, California....................23

11. Map showing contoured isostatic residual gravity field, Antelope Valley, California ....26

12. Map showing the thickness of the valley-fill deposits calculated from gravity measurements in the Palmdale area, Antelope Valley, California 


\section{Figures-Continued}

13. Map showing locations of seismic refraction and reflection surveys and direct current (DC) resistivity surveys along Amargosa Creek near Palmdale, California ........29

14. Graphs showing seismic data collected along Amargosa Creek near Palmdale, California: $A$, seismic reflection, and $B$, average $P$-wave velocity images for the seismic line, and $C$, resistivity models for resistivity lines 1 and 2, 2009

15. Map showing line of section, model domain, model boundary location, type of boundary and location of Amargosa Creek Recharge Project, Antelope Valley, California

16. Schematics showing generalized geologic cross section for the Palmdale and Lancaster area, Antelope Valley, California.

17. Schematic showing simplified geologic cross section used for model simulations beneath the Amargosa Creek Recharge Project and vicinity, Antelope Valley, California

18. Map showing extended model domain, model boundary location, type of boundary and location of Amargosa Creek Recharge Project, Antelope Valley, California.

19. Map showing scenario 1, change in head after 20-year artificial-recharge simulation, assuming that layer 1 hydraulic conductivity was equal to 10 feet per day and an artificial-recharge rate of 3,400 acre-feet per year, Antelope Valley, California

20. Map showing scenario 2, change in head after 20-year artificial-recharge simulation, assuming that layer 1 hydraulic conductivity was equal to 100 feet per day and an artificial-recharge rate of 9,400 acre-feet per year, Antelope Valley, California

\section{Tables}

1. Well-site list and construction data for selected wells near Palmdale, Los Angeles County, California.

2. Field measurements and water-quality data for water from selected monitoring wells near Palmdale, Los Angeles County, California, 2009-13.

3. Nutrient and organic carbon data for water from selected monitoring wells near Palmdale, Los Angeles County, California, 2009-13.

4. Regulated volatile organic compounds data for water from selected monitoring wells near Palmdale, Los Angeles County, California, 2009-12.

5. Isotopic data for water from selected monitoring wells near Palmdale, Los Angeles County, California, 2009-13.

6. Isotopic data for water from selected wells near Palmdale, California, 1997-2013 .......21

7. Thickness of alluvial deposits from drillers' logs and gravity surveys for 14 wells near Palmdale, Los Angeles County, California...

8. Estimated density contrast with depth in the Palmdale area 


\section{Conversion Factors}

Inch/Pound to SI

\begin{tabular}{|c|c|c|}
\hline Multiply & By & To obtain \\
\hline \multicolumn{3}{|c|}{ Length } \\
\hline inch (in.) & 2.54 & centimeter $(\mathrm{cm})$ \\
\hline foot $(\mathrm{ft})$ & 0.3048 & meter $(\mathrm{m})$ \\
\hline mile (mi) & 1.609 & kilometer $(\mathrm{km})$ \\
\hline \multicolumn{3}{|c|}{ Area } \\
\hline acre & 4,047 & square meter $\left(\mathrm{m}^{2}\right)$ \\
\hline square mile $\left(\mathrm{mi}^{2}\right)$ & 259.0 & hectare (ha) \\
\hline \multicolumn{3}{|c|}{ Volume } \\
\hline gallon (gal) & 3.785 & liter (L) \\
\hline cubic foot $\left(\mathrm{ft}^{3}\right)$ & 0.02832 & cubic meter $\left(\mathrm{m}^{3}\right)$ \\
\hline acre-foot (acre-ft) & 1,233 & cubic meter $\left(\mathrm{m}^{3}\right)$ \\
\hline \multicolumn{3}{|c|}{ Flow rate } \\
\hline acre-foot per year (acre-ft/yr) & 1,233 & cubic meter per year $\left(\mathrm{m}^{3} / \mathrm{yr}\right)$ \\
\hline foot per second (ft/s) & 0.3048 & meter per second $(\mathrm{m} / \mathrm{s})$ \\
\hline foot per day $(\mathrm{ft} / \mathrm{d})$ & 0.3048 & meter per day $(\mathrm{m} / \mathrm{d})$ \\
\hline \multicolumn{3}{|c|}{ Density } \\
\hline pound per cubic foot $\left(\mathrm{lb} / \mathrm{ft}^{3}\right)$ & 16.02 & kilogram per cubic meter $\left(\mathrm{kg} / \mathrm{m}^{3}\right)$ \\
\hline \multicolumn{3}{|c|}{ Radioactivity } \\
\hline picocurie per liter $(\mathrm{pCi} / \mathrm{L})$ & 0.037 & becquerel per liter $(\mathrm{Bq} / \mathrm{L})$ \\
\hline \multicolumn{3}{|c|}{ Specific capacity } \\
\hline gallon per minute per foot $[(\mathrm{gal} / \mathrm{min}) / \mathrm{ft})]$ & 0.2070 & liter per second per meter $[(\mathrm{L} / \mathrm{s}) / \mathrm{m}]$ \\
\hline \multicolumn{3}{|c|}{ Hydraulic conductivity } \\
\hline foot per day (ft/d) & 0.3048 & meter per day $(\mathrm{m} / \mathrm{d})$ \\
\hline
\end{tabular}

\section{Supplemental Information}

Temperature in degrees Celsius $\left({ }^{\circ} \mathrm{C}\right)$ may be converted to degrees Fahrenheit $\left({ }^{\circ} \mathrm{F}\right)$ as follows:

${ }^{\circ} \mathrm{F}=\left(1.8 x^{\circ} \mathrm{C}\right)+32$

Temperature in degrees Fahrenheit $\left({ }^{\circ} \mathrm{F}\right)$ may be converted to degrees Celsius $\left({ }^{\circ} \mathrm{C}\right)$ as follows:

${ }^{\circ} \mathrm{C}=\left({ }^{\circ} \mathrm{F}-32\right) / 1.8$

*Transmissivity: The standard unit for transmissivity is cubic foot per day per square foot times foot of aquifer thickness [ $\left.\left[\mathrm{ft}^{3} / \mathrm{d}\right) / \mathrm{ft}^{2}\right] \mathrm{ft}$. In this report, the mathematically reduced form, foot squared per day $\left(\mathrm{ft}^{2} / \mathrm{d}\right)$, is used for convenience.

Specific conductance is given in microsiemens per centimeter at 25 degrees Celsius $(\mu \mathrm{S} / \mathrm{cm}$ at $\left.25^{\circ} \mathrm{C}\right)$.

Concentrations of chemical constituents in water are given either in milligrams per liter (mg/L) or micrograms per liter $(\mu \mathrm{g} / \mathrm{L})$. 


\section{Datum}

Vertical coordinate information is referenced to the North American Vertical Datum of 1988 (NAVD 88).

Altitude, as used in this report, refers to distance above the vertical datum.

\section{Abbreviations}

\begin{tabular}{ll} 
ACRP & Amargosa Creek Recharge Project \\
BCM & Basin Characteristic Model \\
bls & below land surface \\
DC & direct current \\
DOC & dissolved organic carbon \\
Hz & hertz \\
GPS & Global Positioning System \\
MCL & maximum contaminant level \\
NRP & National Research Program \\
NWOL & National Water Quality Laboratory \\
pmc & percent modern carbon \\
PVC & polyvinyl chloride \\
Qoa & old alluvial valley deposits/Pleistocene \\
Ovoa & very old alluvial valley deposits/Pleistocene \\
Oyf & young alluvial fan deposits/Holocene to early Pleistocene \\
Ovol & very fold lacustrine deposits/early Pleistocene to late Pleistocene \\
RTK & Real Time Kinematic \\
SWP & State Water Project \\
TU & tritium units \\
UPW & upstream weighted package \\
EPA & U.S. Environmental Protection Agency \\
USGS & U.S. Geological Survey \\
VOC & volatile organic compound \\
ybp & years before present \\
\hline
\end{tabular}




\section{Acknowledgments}

The authors acknowledge the cooperation and assistance of the city of Palmdale in providing funding for the study and logistical support in the field. The authors also thank local land owners for access to their property during collection of field data.

The authors would also like to thank the reviewers of this report. Their reviews provided insightful comments and suggestions that greatly improved the quality of the report. 


\title{
Feasibility and Potential Effects of the Proposed Amargosa Creek Recharge Project, Palmdale, California
}

\author{
By Allen H. Christensen, Adam J. Siade, Peter Martin, Victoria E. Langeheim, Rufus D. Catchings, and \\ Matthew K. Burgess
}

\section{Abstract}

Historically, the city of Palmdale and vicinity have relied on groundwater as the primary source of water, owing, in large part, to the scarcity of surface water in the region. Despite recent importing of surface water, groundwater withdrawal for municipal, industrial, and agricultural use has resulted in groundwater-level declines near the city of Palmdale in excess of 200 feet since the early 1900s. To meet the growing water demand in the area, the city of Palmdale has proposed the Amargosa Creek Recharge Project (ACRP), which has a footprint of about 150 acres along the Amargosa Creek 2 miles west of Palmdale, California. The objective of this study was to evaluate the long-term feasibility of recharging the Antelope Valley aquifer system by using infiltration of imported surface water from the California State Water Project in percolation basins at the ACRP.

Three monitoring sites were constructed, and geophysical surveys (gravity, seismic, and resistivity) were completed to define the thickness of valley-fill deposits, depth to water, and location of faults that could influence groundwater flow. Data collected at the monitoring sites, and results from the geophysical surveys, were used to identify three northwestsoutheast trending faults in the vicinity of the proposed recharge facility; these faults are probably related to the nearby San Andreas fault zone. Water levels collected from wells at the monitoring sites showed water-level altitude differences as much as 230 feet between the upgradient and downgradient sides of the faults, indicating that these faults are barriers to groundwater flow. Lithologic and geophysical logs indicated the presence of a coarse gravel and sand unit extending from land surface to about 150 feet below land surface that did not appear to be disrupted by faulting.

Water samples collected from the monitoring wells were analyzed for major ions, nutrients, trace elements, dissolved organic carbon, volatile organic compounds, stable isotopes of oxygen (oxygen-18) and hydrogen (hydrogen-2, or deuterium), and the radioactive isotopes of hydrogen (hydrogen-3, or tritium) and carbon (carbon-14, or ${ }^{14} \mathrm{C}$ ) to determine the water quality of the aquifer system and to help determine the source and age of the groundwater. Results of the water-quality analysis indicated that the source of natural recharge is Amargosa Creek near the ACRP, but that the creek does not provide modern-day recharge downstream of the ACRP.

Potential effects of artificial recharge at the ACRP were evaluated by using a local-scale model of groundwater flow. On the basis of geologic samples collected during drilling, the hydraulic conductivity of the sand and gravel unit in the upper 150 feet was assumed to range from 10 to 100 feet per day. To address the goal of minimizing the potential for liquefaction during an earthquake from water-table rise associated with groundwater recharge at the ACRP, simulated water levels were constrained to remain at least 50 feet below land surface, except beneath the proposed artificial-recharge facility.

The hydraulic conductivities of faults were estimated on the basis of water-level data and an estimate of natural recharge along Amargosa Creek. With assumed horizontal hydraulic conductivities of 10 and 100 feet per day in the upper 150 feet, the simulated maximum artificial recharge rates to the regional flow system at the ACRP were 3,400 and 9,400 acre-feet per year, respectively. These maximum recharge rates were limited primarily by the horizontal hydraulic conductivity in the upper 150 feet and by the liquefaction constraint. Future monitoring of water-level and soil-water content changes during the proposed project would allow improved estimation of aquifer hydraulic properties, the effect of the faults on groundwater movement, and the overall recharge capacity of the ACRP.

\section{Introduction}

Historically, the city of Palmdale and vicinity have relied on groundwater as the primary source of water, owing, in large part, to the scarcity of surface water in the region. Since 1972, supplemental surface water has been imported from the California State Water Project (SWP) through the California Aqueduct to help meet the demand for water. Despite the importation of surface water, groundwater withdrawal for municipal, industrial, and agricultural use has resulted in groundwater-level declines in excess of $200 \mathrm{feet}(\mathrm{ft})$ near the city of Palmdale since the early 1900s (Christensen, 1999). 
To meet the growing demand for water in the area, the city of Palmdale has proposed the Amargosa Creek Recharge Project (ACRP). The ACRP plans to use the SWP water to artificially recharge the Antelope Valley groundwater system through percolation basins.

\section{Purpose and Scope}

In 2008, the U.S. Geological Survey (USGS) and the city of Palmdale entered into a cooperative agreement to investigate the feasibility and potential hydrologic effects of artificially recharging the groundwater system by infiltrating surface water from the SWP into percolation basins near Amargosa Creek. The purpose of this study was to evaluate the long-term feasibility of the proposed artificial recharge program by improving the understanding of the hydrogeology and geochemistry of the aquifer system underlying the study area and by simulating the potential hydrologic effects of artificial-recharge for a range of aquifer properties. Specifically, the study seeks to estimate a plausible range of artificial recharges rates by using a newly developed groundwater model and various aquifer property scenarios. Several methods were used to help characterize the thickness of valley-fill deposits, the basement geometry, and geologic features that could influence groundwater flow, including regional gravity surveys, seismic refraction and reflection surveys, resistivity surveys, and test borings completed with monitoring wells. Data collected as part of this study and previous studies were used to develop a local-scale numerical groundwater-flow model to simulate changes in water levels and flow resulting from artificial recharge. The calibrated model was used to evaluate the potential effects of two longterm recharge water-management scenarios.

\section{General Description of Study Area}

The ACRP is in the southwestern part of the Antelope Valley, approximately 4 miles (mi) west of Palmdale, in Los Angeles County, California (fig. 1). The proposed ACRP site comprises approximately 150 acres along Amargosa Creek near the San Gabriel Mountain front where the Creek exits Leona Valley (fig. 2). The Amargosa Creek drainage basin covers approximately 30 square miles $\left(\mathrm{mi}^{2}\right)$ in the Leona Valley along the San Andreas fault zone in the eastern San Gabriel Mountains with land surface elevation varying from 2,750 to 5,200 ft. Amargosa Creek provides drainage for the Leona Valley, then extends southeast from Leona Valley across the San Andreas fault zone on the west side of the city of Palmdale, before turning north near Lancaster and terminating at Rosamond Dry Lake (fig. 2).

Average annual precipitation at local weather stations (fig. 2) ranged from about 8 inches (in.) at Palmdale and at Vincent, south of Palmdale, to about 18 in. at Pine Canyon
(Western Regional Climate Center, 2011a, 2011b, 2011c). Average annual discharge measurements along Amargosa Creek were not available, but estimates varied between 170 (L.E. Flint, U.S. Geological Survey, written commun., 2011) and 800 acre-feet per year (acre-ft/yr; Los Angeles County Department of Public Works, 1991). Flows in Amargosa Creek are intermittent and usually only run during the winter rainy season or, infrequently, as a result of late summer monsoonal storms (Bloyd, 1967). Although the study focus was near the proposed ACRP, the study area was expanded to include western Palmdale, southern Lancaster, and the area west of Little Rock Wash to simulate the surrounding basement geometry better and to help reduce boundary effects in the groundwater-flow model simulations (fig. 2).

\section{Site Characterization}

The geohydrology of the study area was characterized by using previously published reports and maps; collecting and interpreting gravity, seismic, and resistivity surveys; and correlating geophysical and geologic logs from existing wells with those from the monitoring wells constructed as part of this study.

\section{Previous Geohydrologic Studies}

Several previous investigators have completed regional geohydrologic studies in the Antelope Valley area. Early surveys by Johnson (1911) and Thompson (1929) documented historic hydrologic conditions in the valley, describing the rapid development in the 1920 s and the associated regional decline in the water table. Johnson (1911) also described the importance of recharge in the valley from the three main streams on the southwest side of the valley, Big Rock, Little Rock, and Amargosa Creeks. Dibblee (1960) mapped major faults in the valley, including the San Andreas fault zone, which forms the southern boundary of the Antelope Valley (fig. 1). Regional gravity surveying and areal mapping by Mabey (1960) indicated the presence of faults offsetting the basement complex and valley-fill deposits and of many northwest-trending faults that parallel the main strand of the San Andreas fault zone. Bloyd (1967) noted large differences in groundwater-level elevations along the southern boundary of the Antelope Valley near the San Andreas fault zone. Using water-level data, Bloyd (1967) also mapped faults in the valley that trend sub-parallel to the main strand of the San Andreas Fault. These faults form the southern boundary of the Antelope Valley groundwater basin (Bloyd, 1967) and the southern extent of the Lancaster groundwater subbasin (Durbin, 1978; Leighton and Phillips, 2003). A more detailed summary of the geologic setting of the Antelope Valley is provided in Leighton and Phillips (2003). 


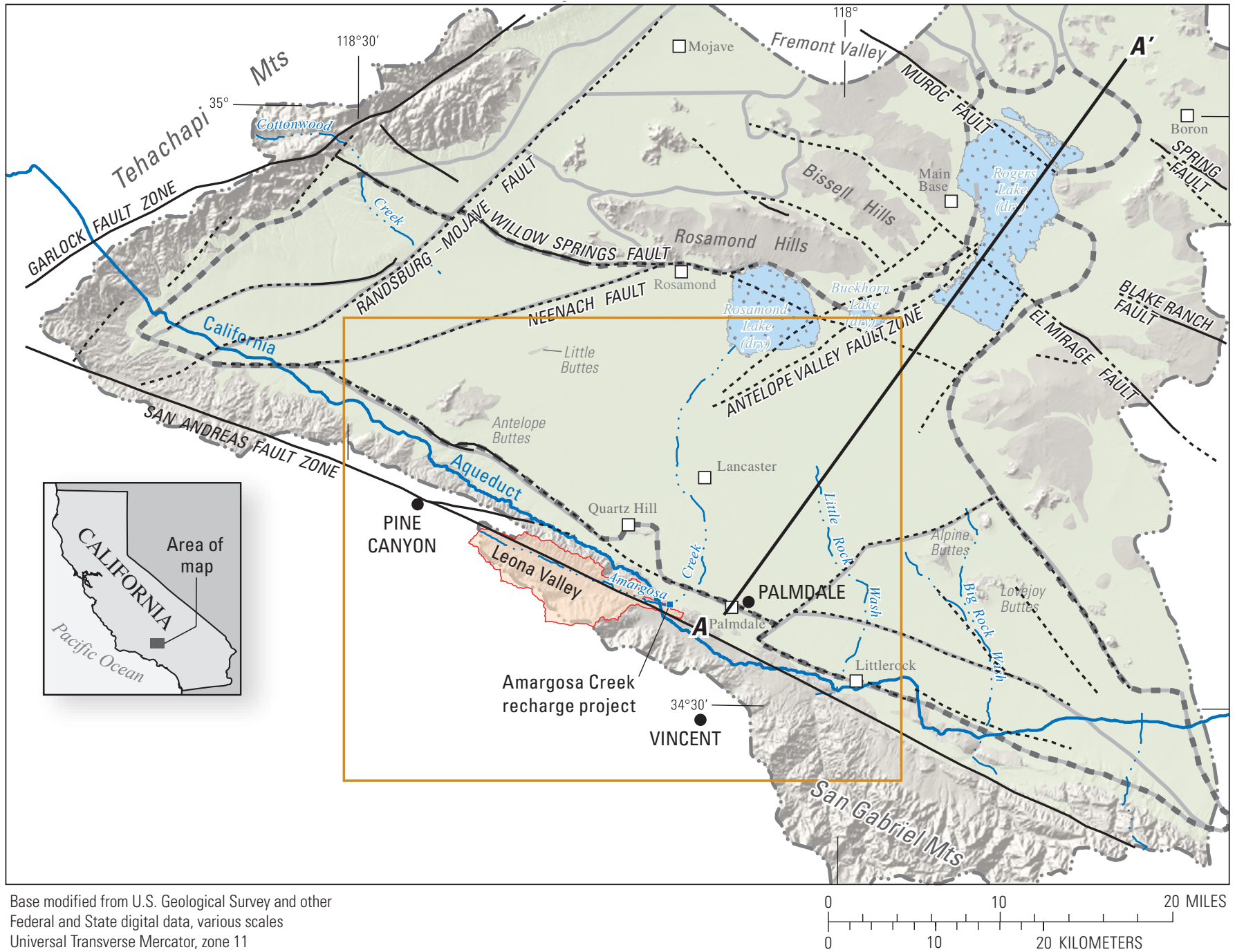

Universal Transverse Mercator, zone 11

North American Datum of 1983

EXPLANATION

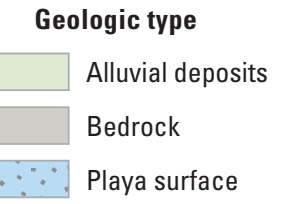

Leona Valley surface-wate drainage basin

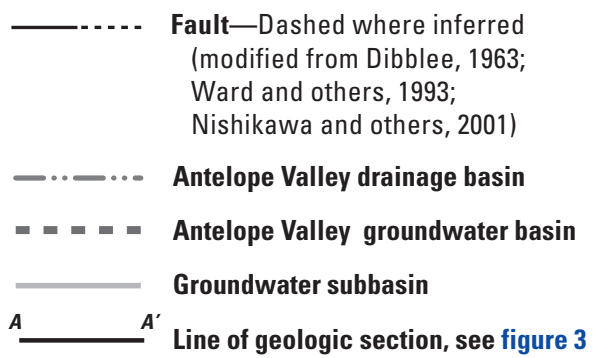

Study area

\section{- Precipitation station VINCENT and name \\ $\square \quad$ City}

Figure 1. Study area and Leona Valley surface-water drainage basin (Amargosa Creek drainage basin), Antelope Valley, California. 


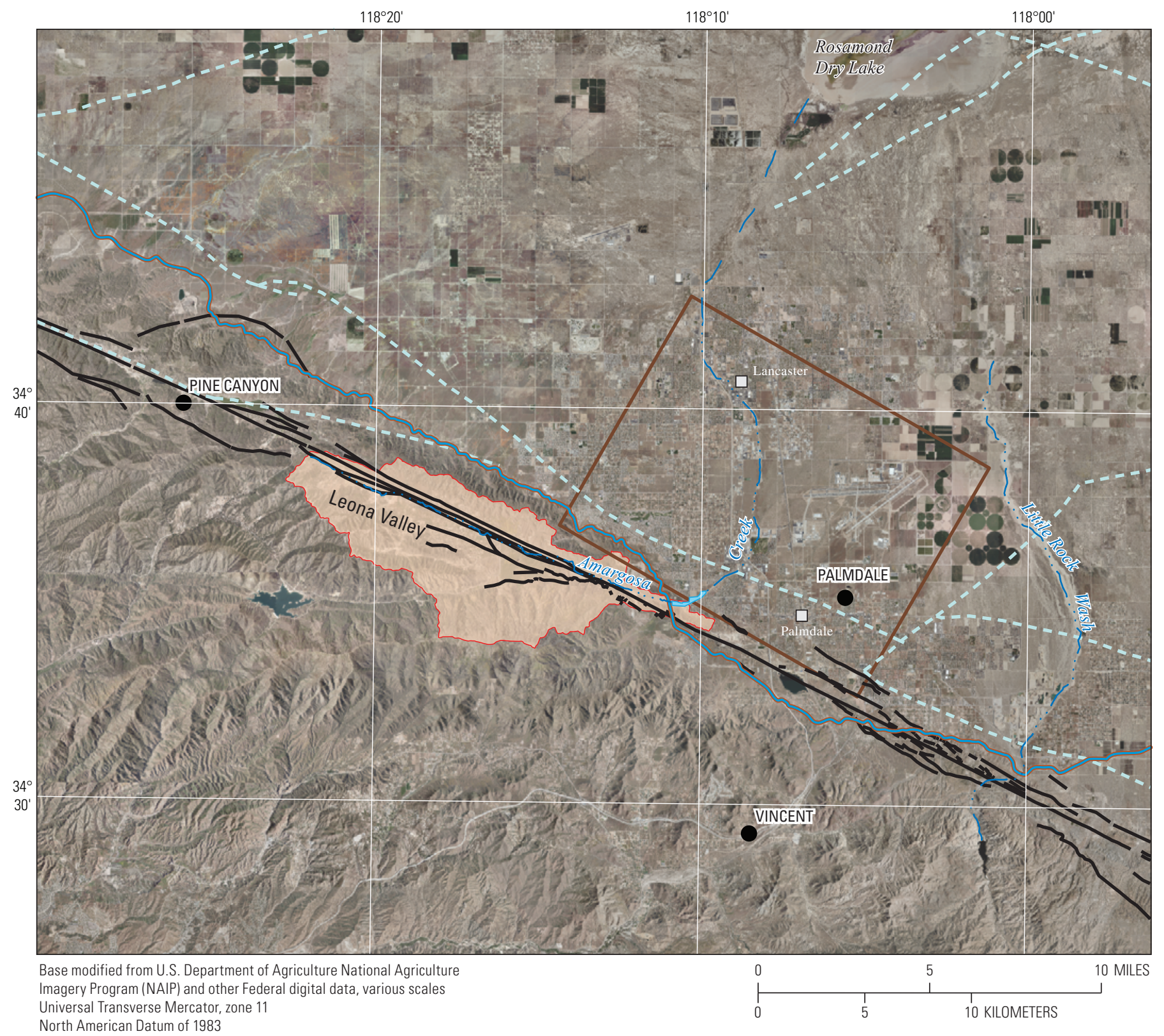

North American Datum of 1983

\section{EXPLANATION}

\begin{tabular}{|l}
\hline Study area \\
$\square \quad \begin{array}{l}\text { Leona Valley } \\
\text { surface-water } \\
\text { drainage basin }\end{array}$ \\
$\begin{array}{c}\text { Proposed recharge } \\
\text { facility }\end{array}$
\end{tabular}

Faults-
San Andreas fault zone $\quad \begin{gathered}\text { California Aqueduct } \\ \text { Inferred fault (Bloyd, 1967) } \\ \text { VINCENT } \begin{array}{l}\text { Precipitation station } \\ \text { and name }\end{array} \\ \square \quad \text { City }\end{gathered}$

Figure 2. Location of study area boundary, Antelope Valley, California. 


\section{Geohydrologic Setting}

Antelope Valley was formed as a result of downfaulted basement and sedimentary fill between the Garlock and the San Andreas fault zones (fig. 1). The basement complex that underlies the sedimentary fill consists of pre-Tertiary igneous and Tertiary sedimentary rocks (Hewett, 1954; Dibblee, 1967). Locally, in the vicinity of the proposed recharge facility, the deepest material encountered during drilling of the monitoring wells showed the basement complex was composed of quartz monzonite. The unconsolidated deposits of Pliocene to Holocene age form the groundwater basin and are more than $5,000 \mathrm{ft}$ thick in places (Dutcher and Worts, 1963).

The unconsolidated units were described by Leighton and Phillips (2003) as lacustrine or alluvial and are divided hydrostratigraphically into the lower, middle, and upper aquifers (fig. 3). The confined lower and confined and unconfined middle aquifers consist of Pliocene and Pleistocene unconsolidated alluvial deposits that become increasingly compacted and indurated with depth and, thus, yield less water to wells with depth (Dutcher and Worts,
1963). The lacustrine deposits, characterized as a thick sequence of blue to blue-green clays, form the confining layer between the middle and lower aquifers in the vicinity of Palmdale (Leighton and Phillips, 2003). The lacustrine deposits vary in age between early Pleistocene in the vicinity of Palmdale, where the lacustrine deposits are at depths in excess of $600 \mathrm{ft}$, to late-Pleistocene near Rodgers Lake, where the unit is exposed at the surface (fig. 3; Leighton and Phillips, 2003). The unconfined upper aquifer consists of Pleistocene to Holocene unconsolidated alluvial deposits derived from local mountains. The upper aquifer readily yields water to wells and is the main production aquifer in the vicinity of Palmdale. For this study, the sedimentary units were grouped into five major units: (1) the lower aquifer, consisting of lower Tertiary deposits (Miocene-Pliocene); (2) lacustrine deposits (Pleistocene-Miocene), (3) the middle aquifer, consisting of relatively indurated old alluvial deposits (Pleistocene); (4) the upper aquifer, consisting of unconsolidated old alluvial deposits (Pleistocene); and (5) young alluvial-fan deposits (Holocene-Pleistocene).

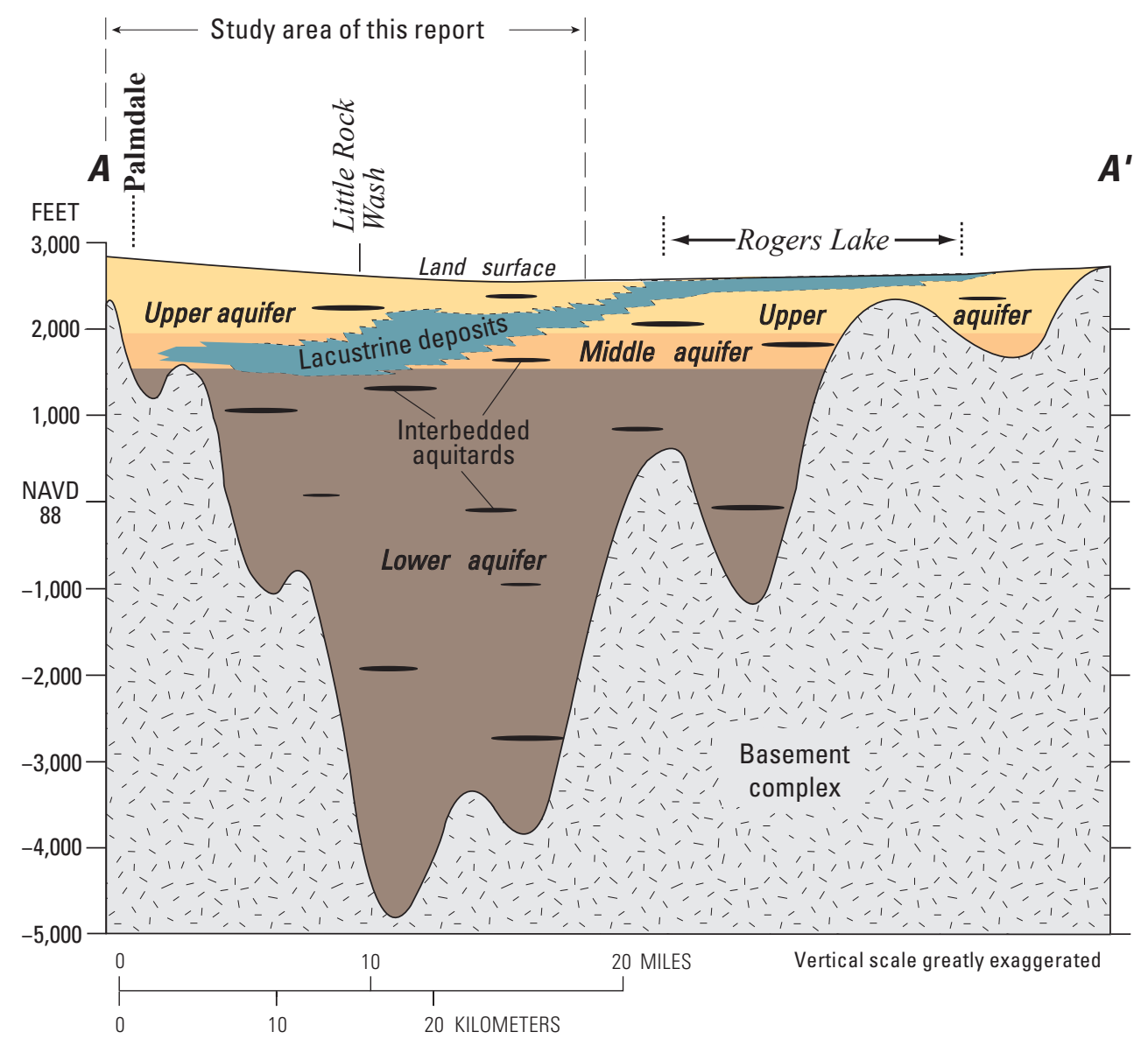

Figure 3. Generalized geologic section showing relation of lacustrine deposits to aquifers in the Antelope Valley groundwater basin, Antelope Valley, California (modified from Londquist and others, 1993). Location of section shown in figure 1. 
These units are laterally and vertically displaced by numerous faults in the valley, particularly along the San Andreas fault zone. Many of these faults form partial barriers to groundwater flow; for example, water-level differences across faults are approximately $300 \mathrm{ft}$ near Palmdale (Christensen, 2005). The barrier effect of faults is probably caused by offsetting of units, compaction, and deformation of water-bearing deposits immediately next to the faults and by cementation from mineral deposition within the fault zone (Londquist and Martin, 1991).

\section{Monitoring Well Construction}

One multiple-well monitoring site and two single-well monitoring sites were completed as part of this study to enable detailed geohydrologic characterization, including depth to basement, lithology, groundwater hydraulic gradients, and groundwater quality near the ACRP. In mid-2009, the USGS Research Drilling Unit constructed two monitoring-well sites along Amargosa Creek using a mud-rotary rig. The first site (site 1) was constructed in the proposed recharge project boundary and the second (site 2) was 1.1 mi northeast of site 1 along Amargosa Creek, downstream from the proposed recharge project (fig. 4, table 1). In March 2011, the city of Palmdale completed an additional monitoring well (site 3) near the northeastern extent of the ACRP boundary and approximately $0.33 \mathrm{mi}$ northeast of site 1 (fig. 4).

\section{Monitoring Site 1}

Monitoring site 1 was constructed by using a large diameter borehole and 8 in. diameter casing to allow for highcapacity aquifer testing. The borehole for site $1(6 \mathrm{~N} / 12 \mathrm{~W}-$ 29B1) was drilled to a depth of $221 \mathrm{ft}$ below land surface (bls) by using a 14.75 in. diameter tri-cone roller drill bit. After the borehole was drilled, a borehole geophysical survey was completed, and a single monitoring well was installed. The monitoring well was constructed by using threaded 8 in. diameter, schedule 40 polyvinyl chloride (PVC) casing that was perforated from 80 to $220 \mathrm{ft}$ bls. The annulus was filled with number 8 sand from the bottom of the borehole to $60 \mathrm{ft}$ bls. A low-permeability bentonite grout was tremied in place from $60 \mathrm{ft}$ bls to land surface to seal the borehole. A generalized well-construction diagram is presented in figure 5 .

Geologic and geophysical data collected at site 1 during construction of the monitoring well were used to define the lithologic and water-bearing properties of the aquifer. Geophysical logs collected at the site included: caliper, natural gamma, conductivity, spontaneous potential, 16-in. and 64-in. normal resistivity, lateral resistivity, electromagnetic induction, and sonic (fig. 5). A generalized description of the lithology is presented in figure 5. The materials from land surface to $150 \mathrm{ft}$ bls are coarse-grained alluvium with minor fines; those from 150 to $220 \mathrm{ft}$ bls are weathered and crystalline quartz-monzonite basement complex.
Depth to water at site 1 was about $103 \mathrm{ft}$ bls after the well was fully developed. The land-surface datum at site 1 is about 2,745 ft; therefore, the water-table elevation measured at the site was about 2,642 ft. After development, the well was pumped at approximately 2.5 gallons per minute (gpm) for 10 hours, resulting in $4 \mathrm{ft}$ of drawdown; therefore, the specific capacity of the well was about 0.6 gallons per minute per foot $(\mathrm{gpm} / \mathrm{ft})$ of drawdown. The pumping rate can change, however, if the depth to water at the site changes.

\section{Monitoring Site 2}

The borehole for site $2(6 \mathrm{~N} / 12 \mathrm{~W}-21 \mathrm{G} 1-4)$ was drilled to a depth of $300 \mathrm{ft}$ bls by using a $14.75 \mathrm{in}$. diameter tri-cone roller drill bit, from 300 to $500 \mathrm{ft}$ bls by using a 12-in. bit, and from 500 to $640 \mathrm{ft}$ bls by using a 9.75 -in. bit. After the borehole was drilled, a geophysical survey was completed, and four monitoring wells constructed with threaded, $2 \mathrm{in.}$ diameter, schedule $40 \mathrm{PVC}$ casing were installed at four depths in the borehole: 620 (21G1), 460 (21G2), 350 (21G3), and 120 (21G4) ft bls (fig. 6). All of the monitoring wells were perforated in the bottom $20 \mathrm{ft}$. The annulus opposite the perforated interval of the monitoring wells was filled with number-3 sand, and a low-permeability bentonite grout was tremied into the annular space between the perforated intervals to effectively isolate the monitoring wells and was emplaced from the top of the sand pack around 21G4 to land surface to seal the borehole. A generalized well-construction diagram is shown in figure 6.

Geologic and geophysical data collected at site 2 during the construction of the monitoring site were used to define the lithologic and water-bearing properties of the aquifer. Geophysical logs collected at the site included caliper, natural gamma, spontaneous potential, 16-in. and 64-in. normal resistivity, electromagnetic induction, and sonic (fig. 6). A generalized description of the lithology is presented in figure 6 . From land surface to about $150 \mathrm{ft}$ bls, the materials consist of medium to coarse sand with gravel and minor interbedding of silts and minor clay; from 150 to $365 \mathrm{ft} \mathrm{bls,}$ the materials consist of fine, medium, and coarse sand with interbedded silty-sand with minor clay; from 365 to $550 \mathrm{ft}$ bls, the materials are similar to the overlying materials, but contain more clays and are more indurated; and from 550 to $630 \mathrm{ft}$ bls, the materials consist of weathered quartz-monzonite basement complex. The resistivity and sonic logs indicated that the basement complex is fractured or weathered from 550 to $630 \mathrm{ft}$ bls.

Depth to water at site 2 (well 21G1) was about $470 \mathrm{ft} \mathrm{bls}$ after the well was fully developed. The land-surface datum at site 2 is about $2,695 \mathrm{ft}$; therefore, the water-table elevation measured at well $21 \mathrm{G} 1$ was about $2,225 \mathrm{ft}$ or about $417 \mathrm{ft}$ below that of site 1 (well 29B1). Because the depth to water was unknown and there is a possibility of existing or future perched water conditions, the shallower monitoring wells at site 2 [21G4 (120 ft bls, dry), 21G3 (350 ft bls, dry), 21G2 (460 ft bls, dry)] were installed above clay layers and 


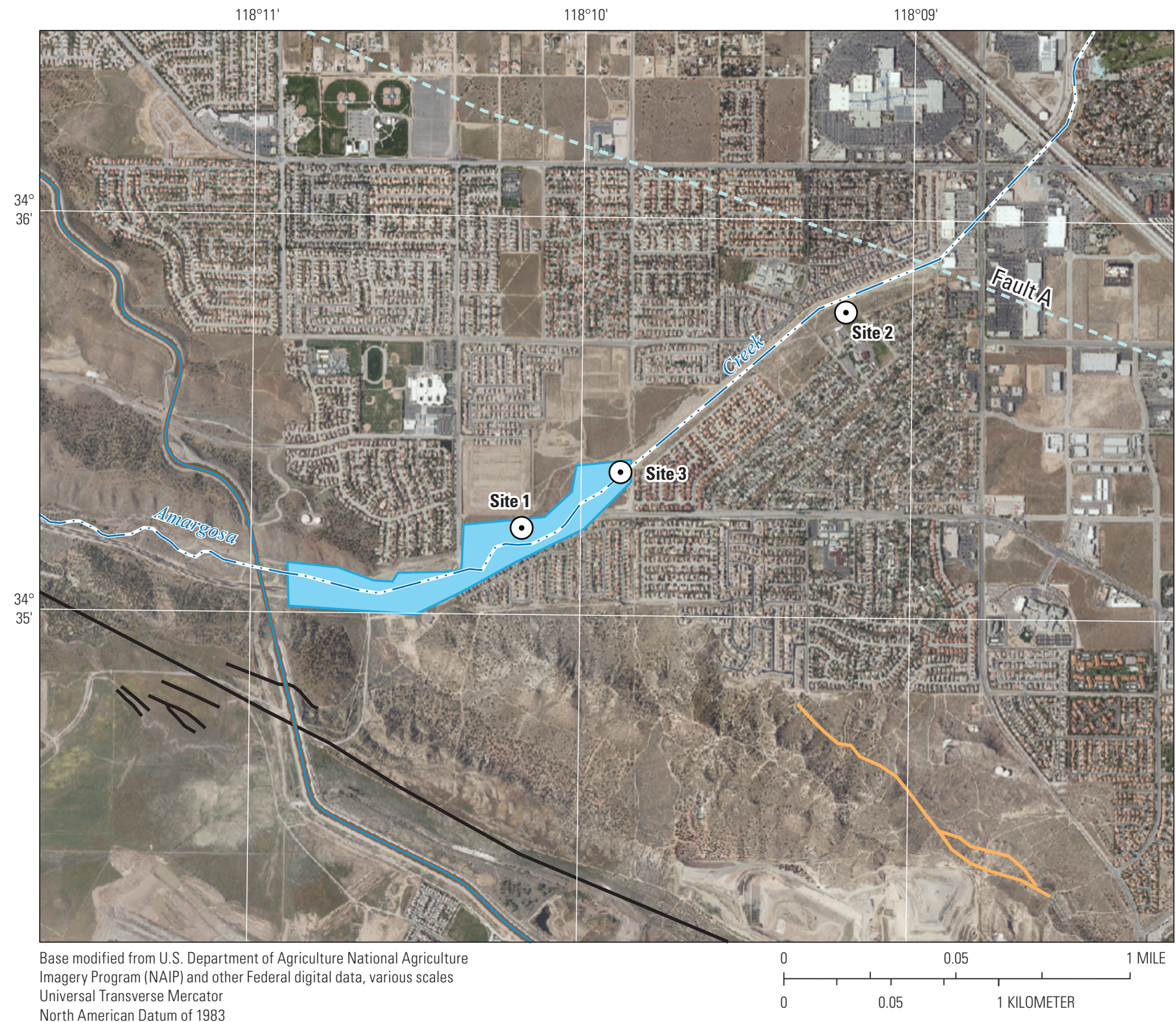

North American Datum of 1983

EXPLANATION

Proposed recharge
facility $\underbrace{\text { San Andreas fault zone }}_{\begin{array}{c}\text { Alquist-Priolo fault (from California } \\ \text { Geological Survey, 2002) } \\ \text { Inferred fault A (Bloyd, 1967) }\end{array}} \odot$ Monitoring-well site

Figure 4. Locations of monitoring sites 1, 2, and 3, near Palmdale, California. 
Feasibility and Potential Effects of the Proposed Amargosa Creek Recharge Project

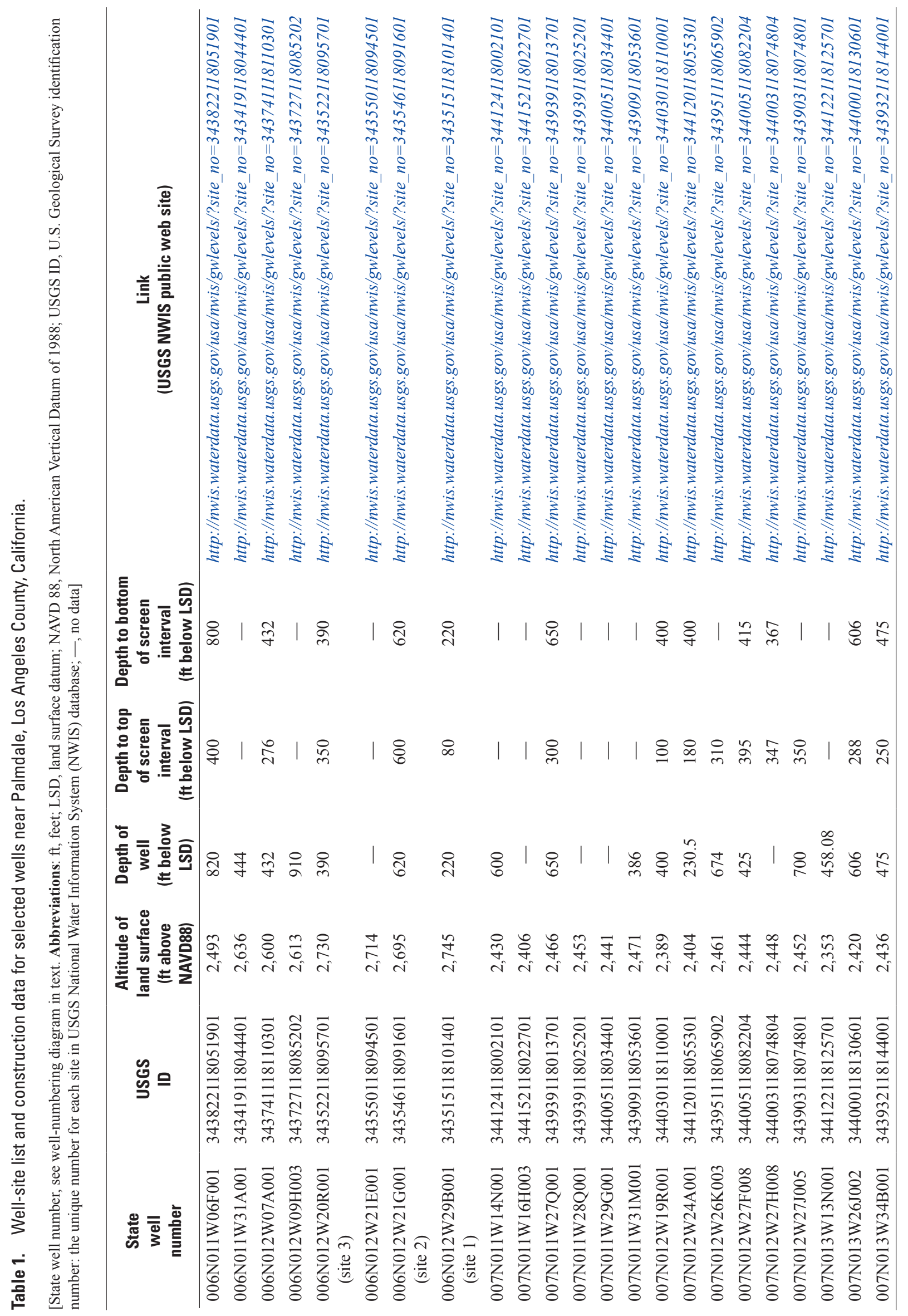




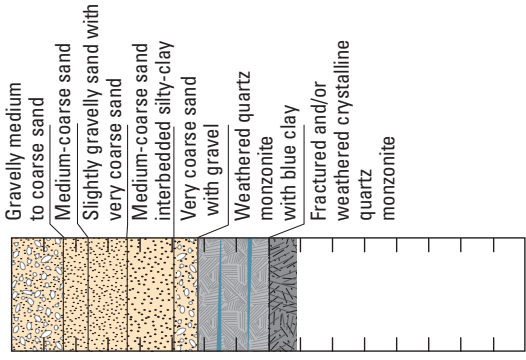

항

962

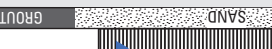

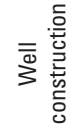

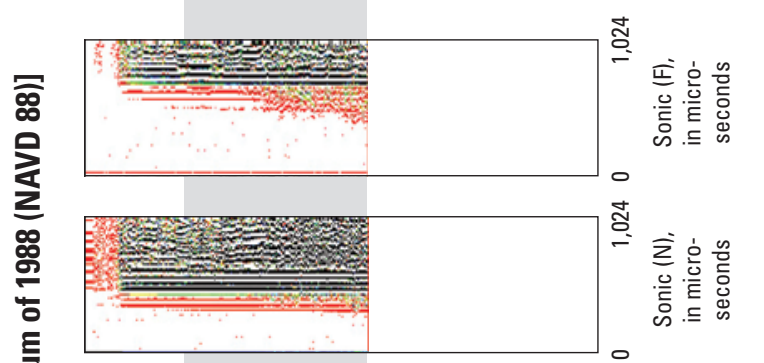

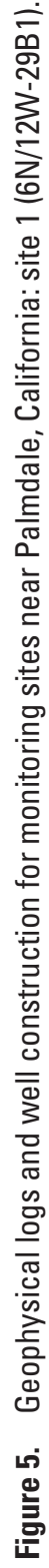




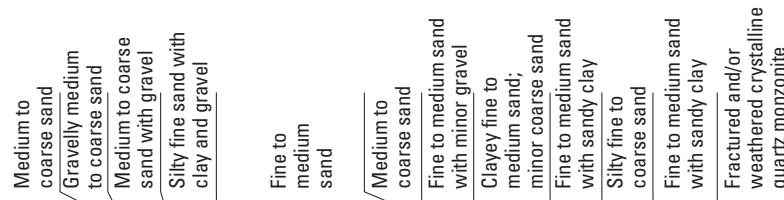
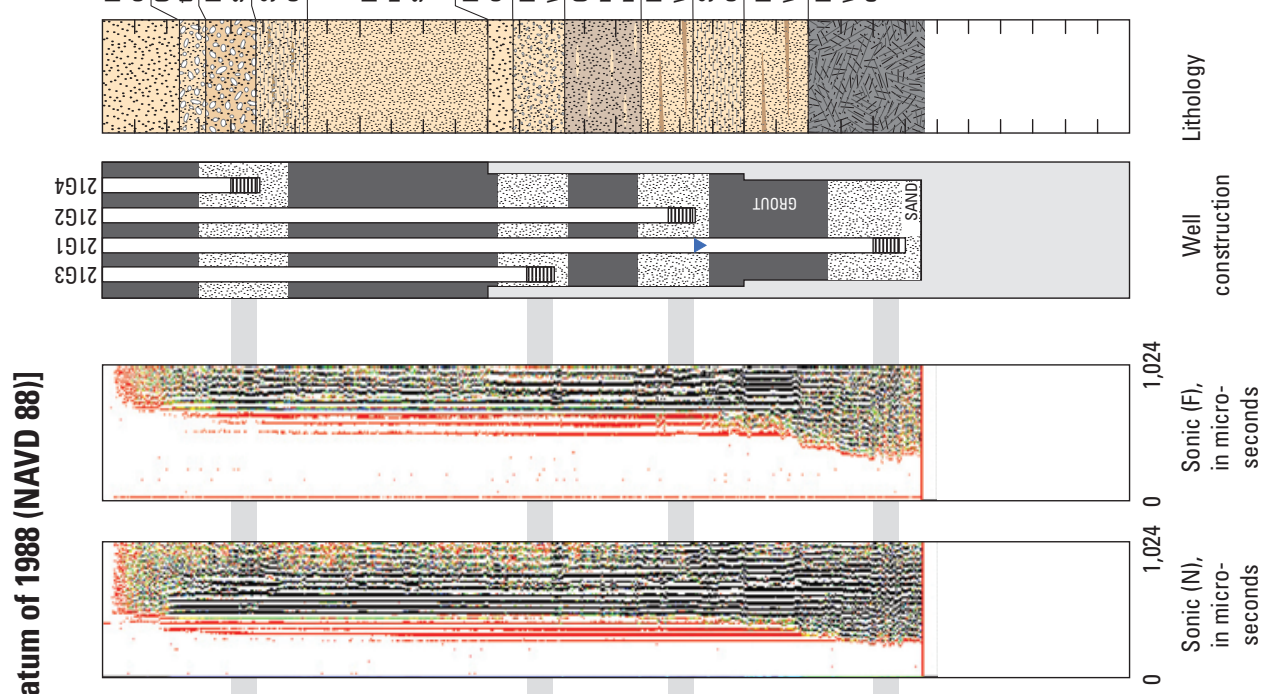

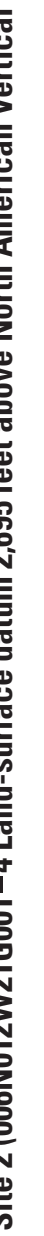

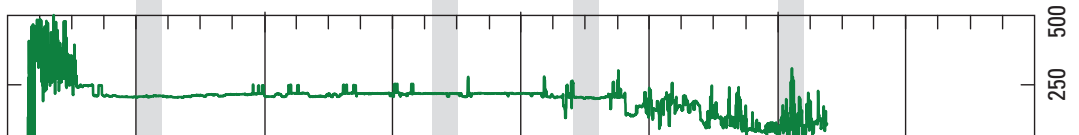

它

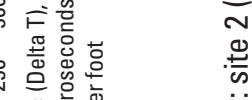
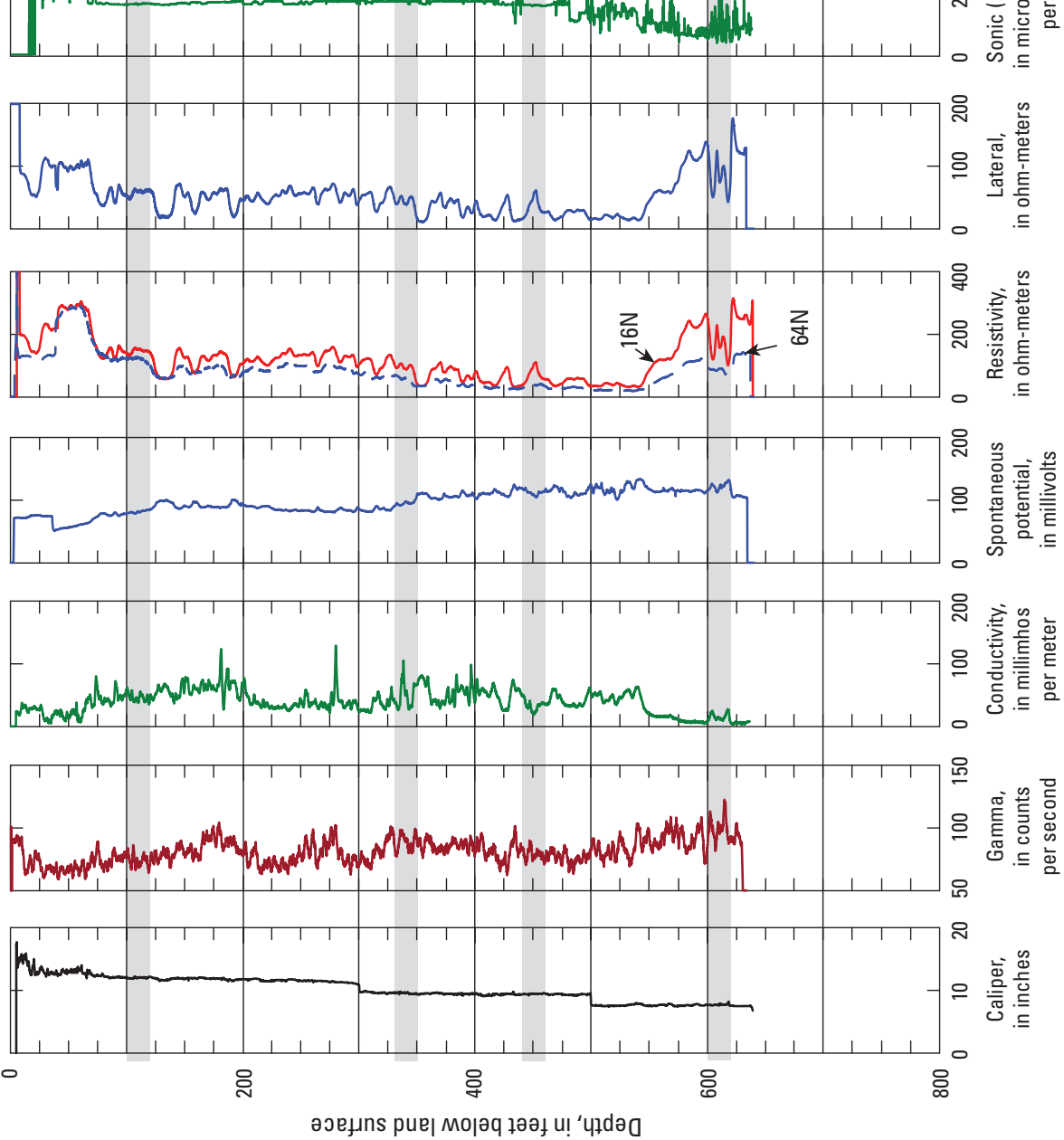
formation changes to monitor potential perching and future rises of the regional water table. At the time of drilling and well development, wells $21 \mathrm{G} 4,21 \mathrm{G} 3$, and $21 \mathrm{G} 2$ were noted as 'dry.' Well 21G1 (620 ft bls) was installed in the fractured or weathered basement complex zone to provide data about the underlying basement complex. Since this well is completed in the uppermost part of the weathered and fractured basement complex, water-level data collected from this well could be representative of the hydraulic head in the deepest overlying alluvium.

\section{Monitoring Site 3}

The borehole for site $3(6 \mathrm{~N} / 12 \mathrm{~W}-20 \mathrm{R} 1)$ was drilled to a depth of $512 \mathrm{ft}$ bls by using a 10.875-in. diameter tri-cone roller drill bit. After the borehole was drilled, a geophysical survey was completed, and the single monitoring well was installed. The monitoring well was constructed with threaded, 3-in. diameter, schedule 40 PVC casing, which was perforated from 350 to $390 \mathrm{ft}$ bls (fig. 7). The annulus was sealed with low-permeability bentonite from the bottom of the hole to
$410 \mathrm{ft}$ bls, with a mixture of number 8 and number 16 sand from 410 to $305 \mathrm{ft}$ bls, and with a concrete seal to the surface (Rottman Drilling, written commun., 2011). A generalized well-construction diagram is presented in figure 7 .

Geologic and geophysical data collected at site 3 during the construction of the monitoring well were used to define the lithology and water-bearing properties of the aquifer. Geophysical logs collected at the site included caliper, natural gamma, spontaneous potential, 16-in. and 64-in. normal resistivity, electromagnetic induction, and sonic (fig. 7). From land surface to about $390 \mathrm{ft}$ bls, the materials consist of gravelly sand with occasional gravel and clay; from 390 to $490 \mathrm{ft}$ bls, the materials consist of cemented silty sand with occasional gravel; from 490 to $512 \mathrm{ft}$ bls, the materials consist of weathered quartz -monzonite basement complex and of fractured and crystalline quartz -monzonite basement complex (fig. 7). The water level at site 3 was about $275 \mathrm{ft}$ bls on April 11, 2011, after the well was developed. The land-surface datum at site 3 is about 2,730 ft; therefore, the water-table elevation measured at the site was about $2,455 \mathrm{ft}$.

Site 3 (6N/12W-20R1 Land-surface datum 2,730 feet above NAVD 88)

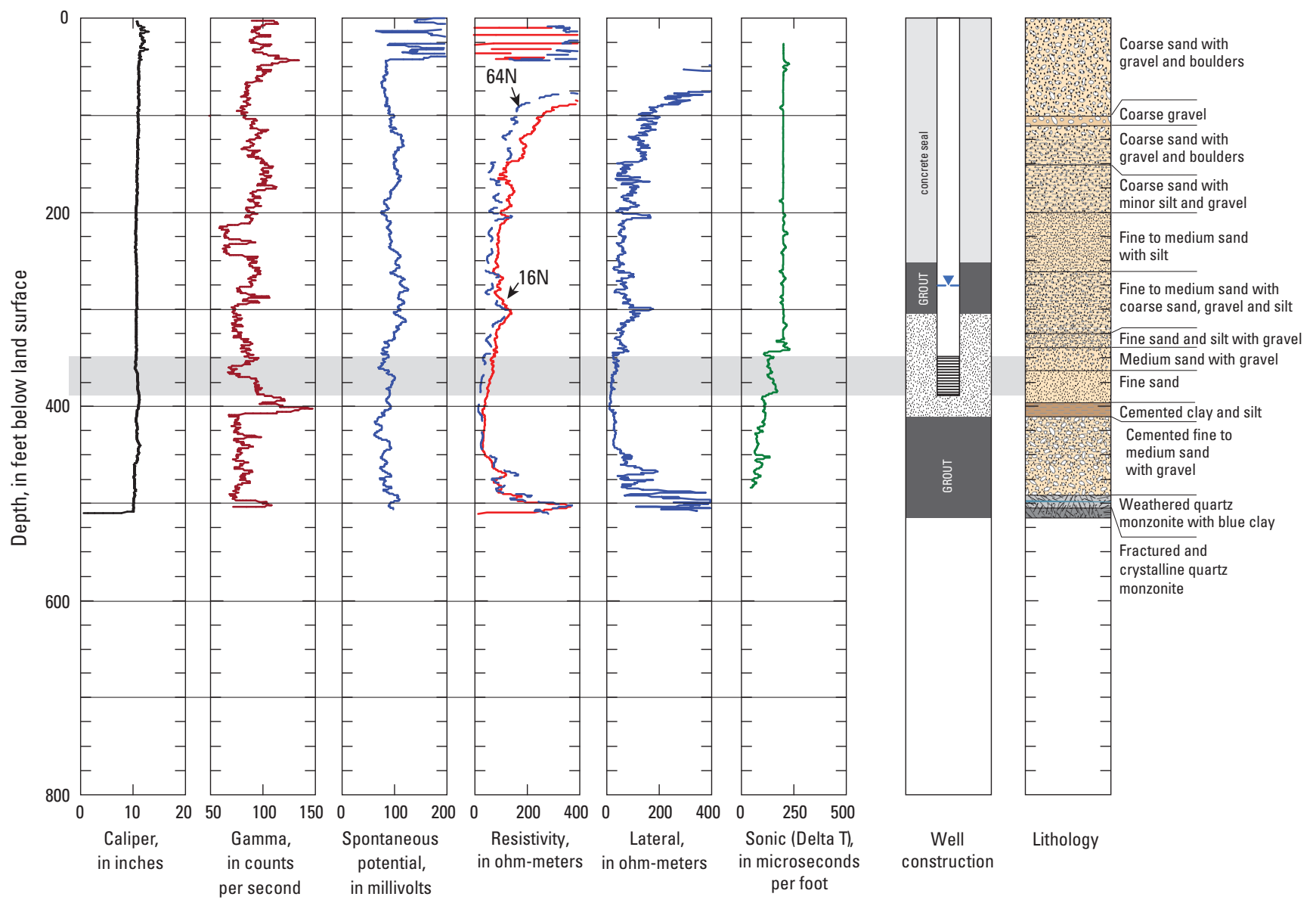

Figure 7. Geophysical logs and well construction for monitoring site 3 (6N/12W-21G001-4), near Palmdale, California. 


\section{Water-Level Data Collected from Monitoring Wells}

In October 2011, the water-level elevation difference between site $1(2,642 \mathrm{ft})$ and site $3(2,454 \mathrm{ft})$ was about $188 \mathrm{ft}$; the water-level difference between sites 3 and 2 (2,224 ft) was $230 \mathrm{ft}$. These differences in water-table elevation among sites indicated the presence of potential groundwater barriers, such as faults, between sites 1 and 3 and between sites 3 and 2. The water-level elevation in well 21G1(site 2) was about $60 \mathrm{ft}$ higher than the water-level elevation in the nearest downstream well measured in the Antelope Valley groundwater basin (2,166 ft ) east of inferred fault A (fig. 8).

\section{Water-Quality Data Collected from Monitoring Wells}

Groundwater samples collected from sites 1, 2, and 3 were analyzed for major ions, nutrients, trace elements, dissolved organic carbon (DOC), volatile organic compounds (VOCs), stable isotopes of oxygen (oxygen-18 or ${ }^{18} \mathrm{O}$ ) and hydrogen (deuterium or ${ }^{2} \mathrm{H}$ ), and the radioactive isotopes of hydrogen (tritium or ${ }^{3} \mathrm{H}$ ) and carbon (carbon-14 or ${ }^{14} \mathrm{C}$ ) to determine the water quality of the aquifer system at these sites and help determine the source and age of the groundwater. VOC samples were collected to determine if the groundwater contained anthropogenic compounds that could come from paints, solvents, or as disinfectant by-products.

\section{Water-Quality Data Collection}

Groundwater samples were collected in accordance with the protocols established by the USGS National Field Manual (U.S. Geological Survey, variously dated). These protocols ensured that samples collected from each well were representative of the groundwater in the aquifer and were handled in a consistent way that minimized the potential for extrinsic contamination of samples. Prior to collecting samples, each well was pumped continuously to purge at least three casing-volumes of water from the well or until field parameters (water temperature, specific conductance, $\mathrm{pH}$, and dissolved oxygen) were stable (Wilde, variously dated). Monitoring wells were sampled by using a pre-cleaned stainless-steel Bennett ${ }^{\circledR}$ submersible piston pump with a Teflon ${ }^{\circledR}$ discharge line. Groundwater and quality-control samples (equipment blank) collected for analysis were shipped within a few days of collection to the USGS National Water Quality Laboratory (NWQL) or other laboratories. Major ions, minor and trace elements, nutrients, organic carbon, and volatile organic compounds were analyzed by the USGS NWQL by various methods as described in Fishman and Friedman (1989), Fishman (1993), Garbarino and others (2006), Patton and Krysalla (2011), Patton and Truitt (1992, 2000), Struzeski and others (1996), Brenton and Arnett (1993), and Connor and others (1998). Tritium activity was measured by the USGS National Research Program (NRP) Tritium-Light Isotope laboratory in Menlo Park, California, by electrolytic enrichment using glass cells with electrodes of nickel and stainless steel (Ostlund and Werner, 1962). Stable hydrogen and oxygen isotopes of water were analyzed by the NRP stable-isotope laboratory in Reston, Virginia (Révész and Coplen, 2008a, 2008b). Carbon-14 and stable isotopes of carbon in organic carbon were analyzed at the Woods Hole Oceanographic Institution by using methods of Karlen and others (1964) and Olsson (1970).

An equipment blank was collected to help determine if the equipment (Bennett ${ }^{\circledR}$ submersible piston pump with a Teflon ${ }^{\circledR}$ discharge line) was a source of contamination for constituents detected in groundwater samples, including anions and cations and selected trace elements. Analytical results of the blank sample showed that most constituents, when detected, were near or below the laboratory reporting levels for each constituent and much lower than concentrations in groundwater samples. The only exceptions were that the iron concentration in the equipment blank was 10.1 micrograms per liter $(\mu \mathrm{g} / \mathrm{L})$ and the aluminum concentration in the blank sample was $5.3 \mu \mathrm{g} / \mathrm{L}$, both above the laboratory reporting level of $3.2 \mu \mathrm{g} / \mathrm{L}$ and $1.7 \mu \mathrm{g} / \mathrm{L}$, respectively; however, these concentrations of iron and aluminum in the blank were 5-10 times lower than the concentrations measured in samples collected for this study (table 2). The uncertainty with respect to the actual concentration of these two constituents in groundwater samples caused by low-level detection in the blank did not have an important effect on the interpretation of the waterquality results.

\section{Physical and Chemical Characteristics}

In general, the water samples collected from sites 1, 2, and 3 indicated that the groundwater in the study area is good quality. Nitrate concentrations in water samples collected from sites 1, 2, and 3 averaged 3.7 milligrams per liter $(\mathrm{mg} / \mathrm{L})$, $0.2 \mathrm{mg} / \mathrm{L}$, and $1.65 \mathrm{mg} / \mathrm{L}$ as nitrogen, respectively (table 3 ). The U.S. Environmental Protection Agency (EPA) maximum contaminant level (MCL) for nitrate is $10 \mathrm{mg} / \mathrm{L}$ as nitrogen (U.S. Environmental Protection Agency, 2005). Fluoride concentrations in samples collected from sites 1, 2, and 3 were $0.9 \mathrm{mg} / \mathrm{L}, 0.6 \mathrm{mg} / \mathrm{L}$, and $0.3 \mathrm{mg} / \mathrm{L}$, respectively (table 2). The EPA MCL for fluoride is $4 \mathrm{mg} / \mathrm{L}$ (U.S. Environmental Protection Agency, 2005). Arsenic concentrations in samples collected from sites 1,2 , and 3 were 1.1 micrograms per liter $(\mu \mathrm{g} / \mathrm{L}), 6.4 \mu \mathrm{g} / \mathrm{L}$, and $1.1 \mu \mathrm{g} / \mathrm{L}$ respectively (table 2$)$. The EPA MCL for arsenic is $0.9 \mu \mathrm{g} / \mathrm{L}$ (U.S. Environmental Protection Agency, 2005).

The concentrations of dissolved organic carbon (DOC) in water samples from sites 1,2 , and 3 were 1.12, 0.48, and, 0.35 (estimated value) $\mathrm{mg} / \mathrm{L}$, respectively; however, because DOC was commonly detected in field blanks at higher concentrations than those detected, the measured concentrations should be regarded with caution (table 3 ). Concentrations of VOCs in samples from sites 1, 2, and 3 were less than detection limits for each analyzed compound (table 4). 


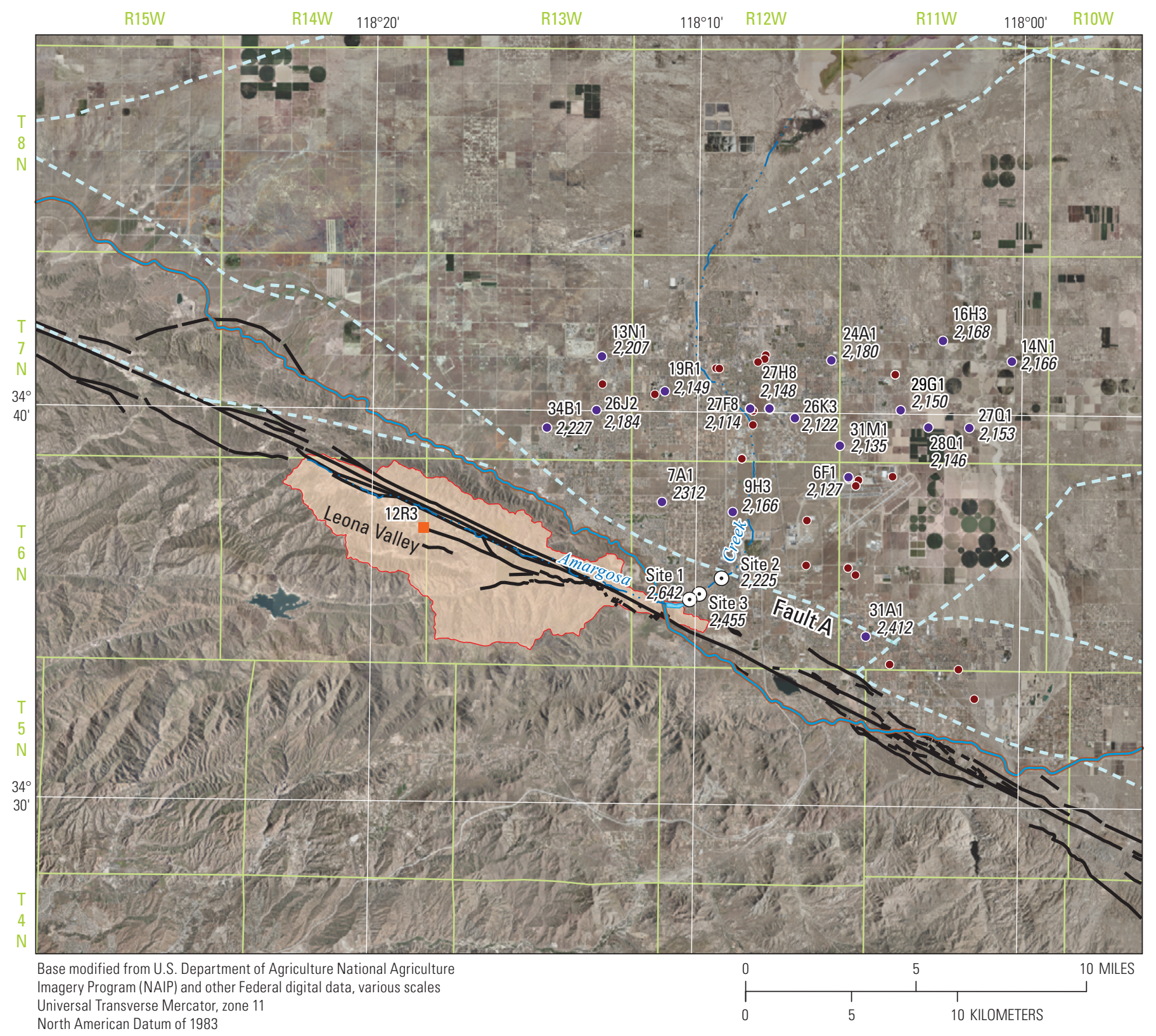

EXPLANATION

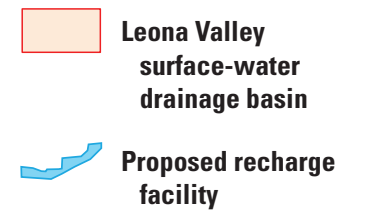
facility
Faults-

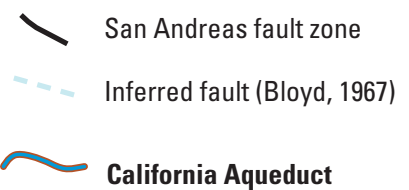

$\odot$ Monitoring-well site

$31 \mathrm{~A} 1$

2,412 Site with water-level data and value (2009)

- Site with stable-isotope data

- Site with stable-isotope data in Leona Valley

Figure 8. Hydraulic head at selected wells, Antelope Valley, California, 2009. 


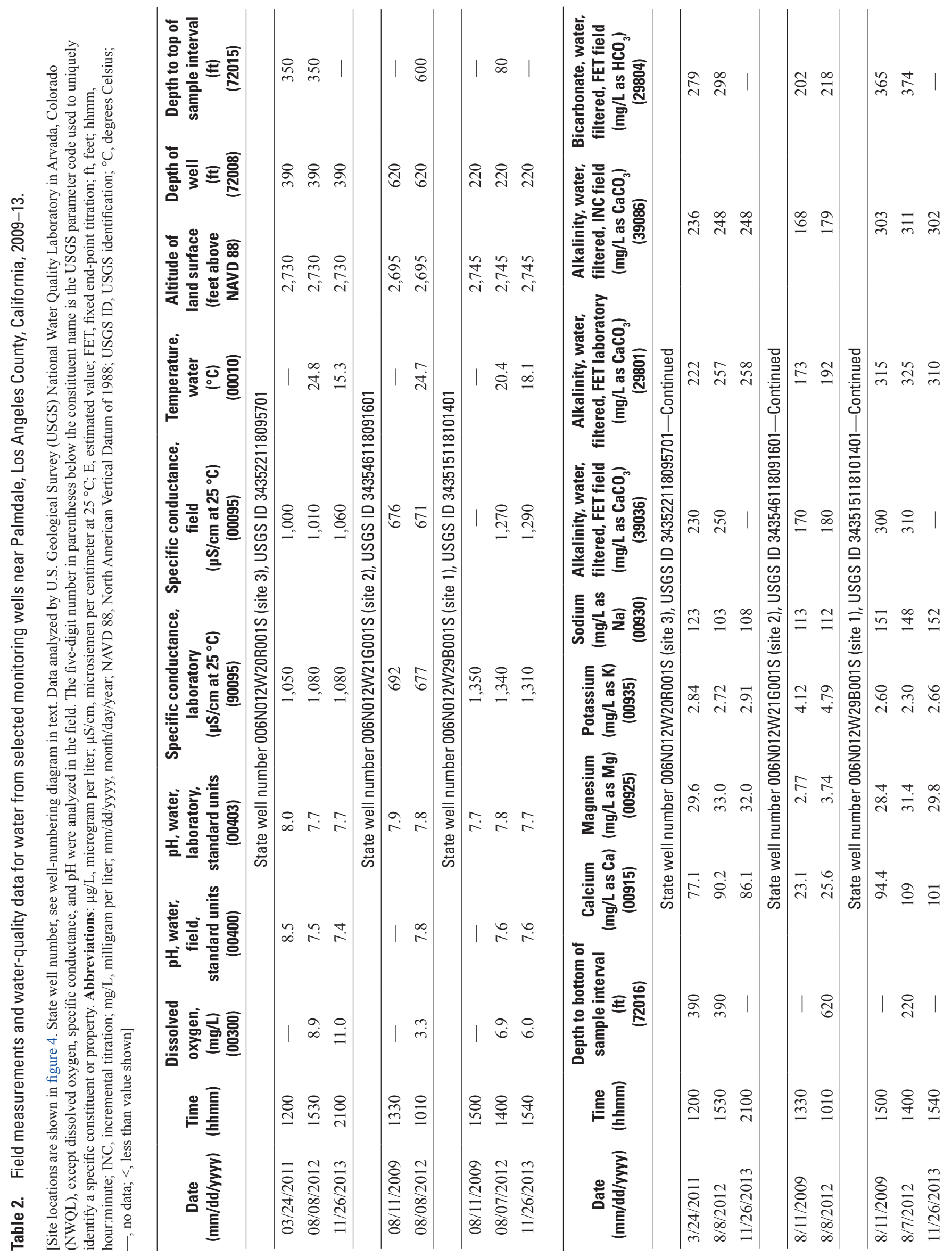




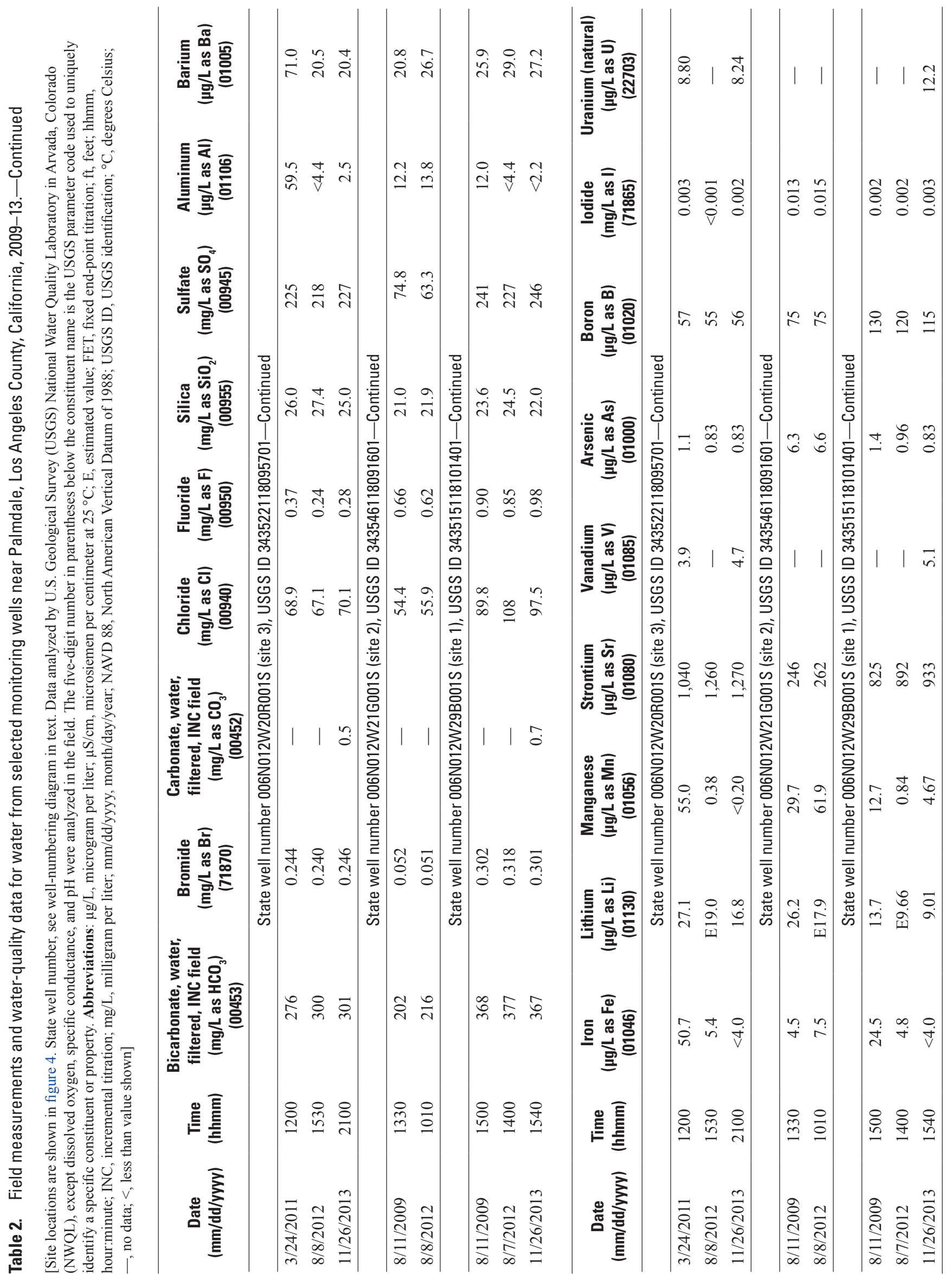


Table 3. Nutrient and organic carbon data for water from selected monitoring wells near Palmdale, Los Angeles County, California, 2009-13.

[State well number, see well-numbering diagram in text. Data analyzed by U.S. Geological Survey (USGS) National Water Quality Laboratory in Arvada, Colorado (NWQL). The five-digit number in parentheses below the constittuent name is the USGS parameter code used to uniquely identify a specific constituent or property. Abbreviations: E, estimated value; ft, feet; hhmm, hour:minute; mg/L, milligram per liter; mm/dd/yyyy, month/day/year; N, nitrogen; NAVD 88, North American Vertical Datum of 1988; P, Phosphorus; USGS ID, USGS identification; -, no data; <, less than value shown]

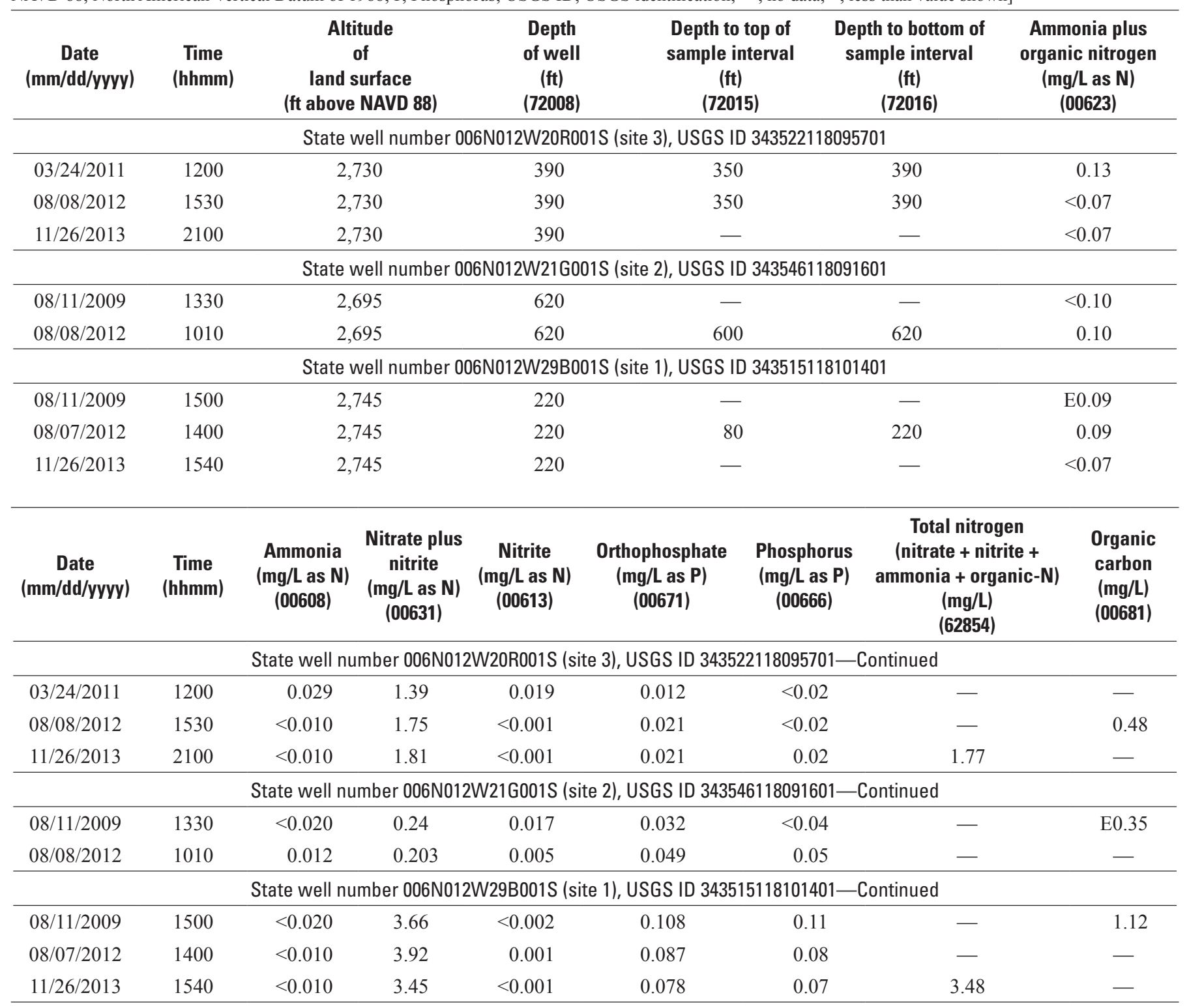


Site Characterization

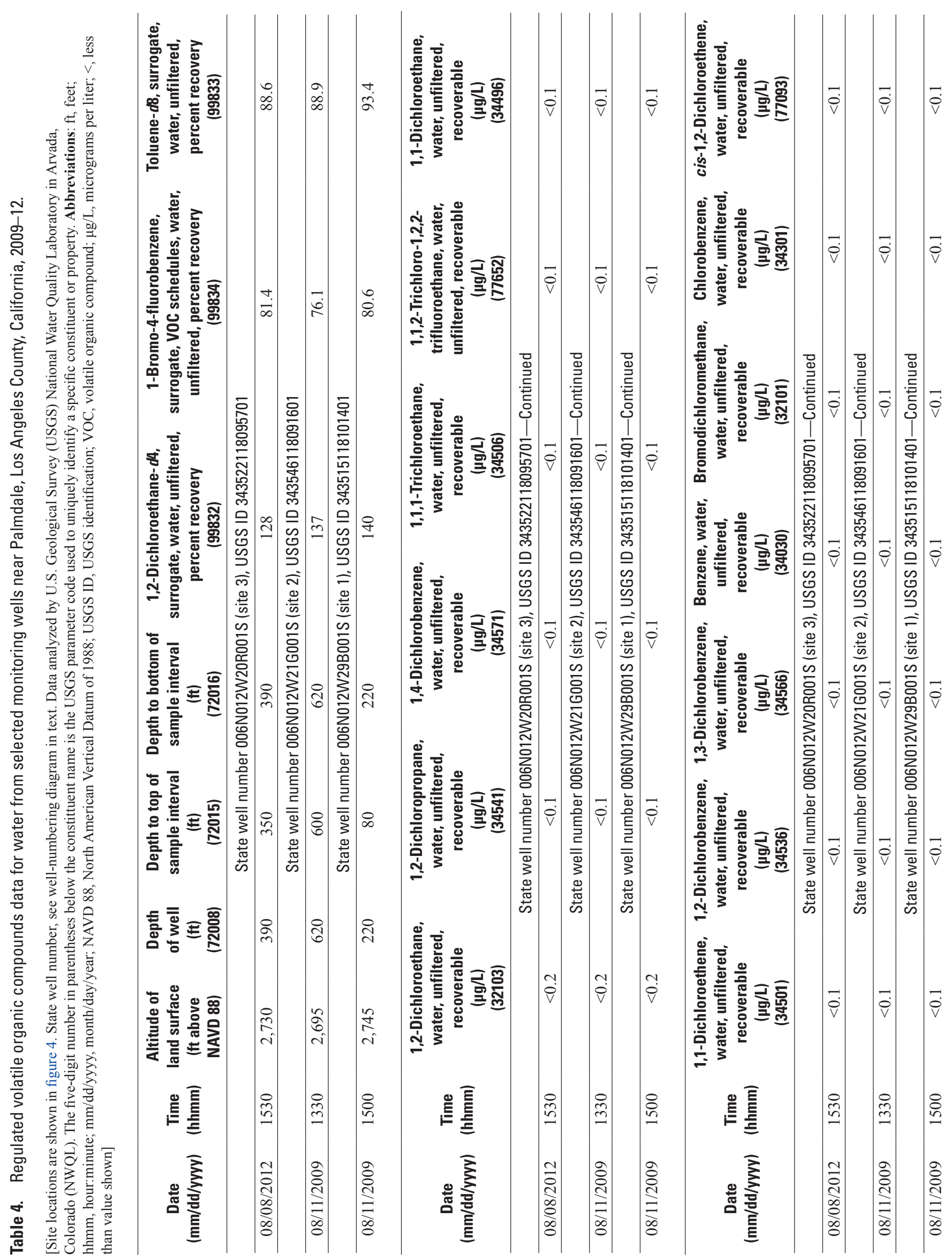




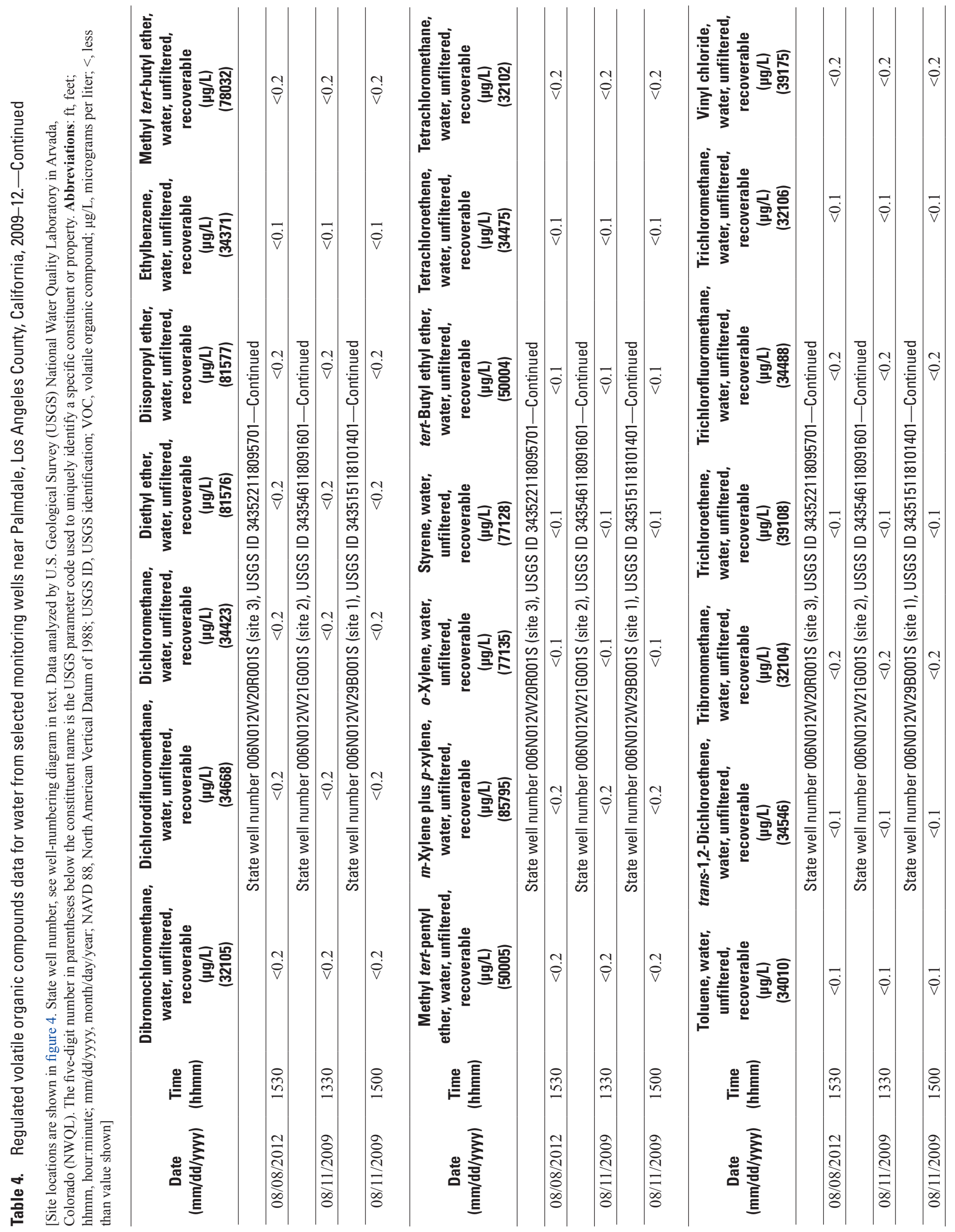




\section{Source and Age of Groundwater}

Samples collected from sites 1, 2, and 3 were analyzed for the stable isotopes oxygen-18 and deuterium to help determine the source of water to wells and to evaluate the movement of water through the study area. Samples collected from sites 1, 2 and 3 were also analyzed for the radioactive isotopes of tritium and carbon-14 to determine the apparent age, or time since recharge, of groundwater.

\section{Stable Isotopes}

Oxygen-18 and deuterium are naturally occurring stable isotopes of oxygen and hydrogen, respectively. The isotopic ratios are expressed in delta notation $(\delta)$ as per mil (parts per thousand) differences relative to the standard known as Vienna Standard Mean Ocean Water (VSMOW) (Gonfiantini, $1978)$. The oxygen $\left(\delta^{18} \mathrm{O}\right)$ and hydrogen $(\delta \mathrm{D})$ isotopic ratios in precipitation throughout the world are linearly correlated because most of the world's precipitation is derived from the evaporation of seawater. This linear relationship is known as the global meteoric water line (Craig, 1961). Differences in isotopic composition can be used to help determine general atmospheric conditions at the time of precipitation as well as the effects of evaporation before water entered the groundwater system. Information about the source and evaporative history of water can be used to evaluate the movement of groundwater. Because groundwater moves slowly, isotopic data collected near the end of long flow lines typically preserve a record of groundwater recharge and movement under predevelopment conditions. This is especially useful in areas where traditional hydrologic data (such as water levels) have been altered by pumping or by changes in recharge and discharge. Additional information regarding the use of stable isotopes in groundwater is available through the USGS at http://wwwrcamnl.wr.usgs.gov/isoig/ isopubs/itchch2.html.

Stable-isotope data were collected from sites 1, 2, and 3 and other wells in the vicinity of the ACRP (fig. 8; tables 5, 6). The $\delta^{18} \mathrm{O}$ and $\delta \mathrm{D}$ measured in the samples collected at sites 1 and 3 were notably heavier (less negative) than the $\delta^{18} \mathrm{O}$ and $\delta \mathrm{D}$ values in samples collected from the Palmdale area and site 2 (fig. 9; tables 5, 6). The $\delta^{18} \mathrm{O}$ and $\delta \mathrm{D}$ values of water sampled at sites 1 and 3 plotted near the sample collected at well $6 \mathrm{~N} / 14 \mathrm{~W}-12 \mathrm{R} 3$, about $7.5 \mathrm{mi}$ west of site 1 along the Amargosa Creek in Leona Valley (figs. 8 and 9). The similarity in isotopic values among these three samples and their proximity to Amargosa Creek indicated that the long-term average isotopic signature of natural modern-day recharge of Amargosa Creek was likely to be represented by these three samples. The sample collected at site 2 plotted near samples collected in the Antelope Valley groundwater basin in the vicinity of Palmdale, but was slightly lighter (more negative) with respect to $\delta^{18} \mathrm{O}$ and $\delta \mathrm{D}$ (fig. 9). This relationship indicated that water collected from site 2 has a similar source as the Palmdale samples, and that modern-day recharge from the Amargosa Creek is not a major source of the water sampled at site 2 or the Palmdale wells. Rather, the source of recharge at site 2 and Palmdale wells is likely to be precipitation that fell at higher elevations in the San Gabriel Mountains.

Tritium

Tritium is a naturally occurring radioactive isotope of hydrogen that has a half-life of 12.4 years (Clark and Fritz, 1997). The concentration of tritium is measured in tritium units (TU); each TU equals 1 atom of tritium in 1,018 atoms of hydrogen. Approximately 800 kilograms of tritium was released to the atmosphere as a result of the atmospheric testing of nuclear weapons between 1952 and 1962 (Michel, 1976). As a result, tritium concentrations in precipitation and groundwater recharge increased beyond naturally occurring concentrations during that time. Tritium concentrations are not affected by chemical reactions other than radioactive decay because tritium is part of the water molecule; therefore, tritium is an excellent tracer of the movement and relative age of water on timescales ranging from recent to about 60 years before present (post atomic bomb). The absence of tritium activity indicates water that infiltrated prior to 1952; high activity indicates water that infiltrated near the time of the bomb peak in the early 1960s; and low activity indicates either very recent recharge or a mixture of water with different ages. In this report, groundwater that had detectable tritium (greater than $0.8 \mathrm{TU}$ ) was interpreted to be water that contained at least some water that was younger than 1952 (post atomic bomb; Clark and Fritz, 1997).

Tritium concentrations in samples from sites 1, 2, and 3 were $1.82,0.15$, and $0.22 \mathrm{TU}$, respectively (table 5). The tritium concentration in water sampled from site 1 was near the concentration in present-day precipitation, indicating at least some contribution from water before 1952 (Clark and Fritz, 1997). The presence of relatively young water at this site is expected given the proximity to the Amargosa Creek and the relatively shallow depth to water (about $100 \mathrm{ft}$ ). The near absence of tritium in the sample collected from site 2 indicated that the water was predominantly recharged prior to 1952 . The low value of $0.15 \mathrm{TU}$ from site 2 was consistent mixing of groundwaters recharged before and after 1952.

\section{Carbon-14}

Carbon-14 is a naturally occurring radioactive isotope of carbon that has a half-life of about 5,730 years (Mook, 1980). Carbon-14 $\left({ }^{14} \mathrm{C}\right)$ data are expressed as percent modern carbon (pmc) by comparing ${ }^{14} \mathrm{C}$ activities of a sample to the specific activity of National Bureau of Standards oxalic acid: 13.56 disintegrations per minute per gram of carbon in the year 1950 equals 100 pmc (Kalin, 2000). Carbon-14 also was produced, as was tritium, by the atmospheric testing of nuclear weapons (Mook, 1980). As a result, ${ }^{14} \mathrm{C}$ activities can exceed $100 \mathrm{pmc}$ in areas where groundwater contains tritium. Carbon-14 activities are used to determine the age of a groundwater sample on timescales ranging from recent to more than 20,000 years before present. Carbon-14 is not 


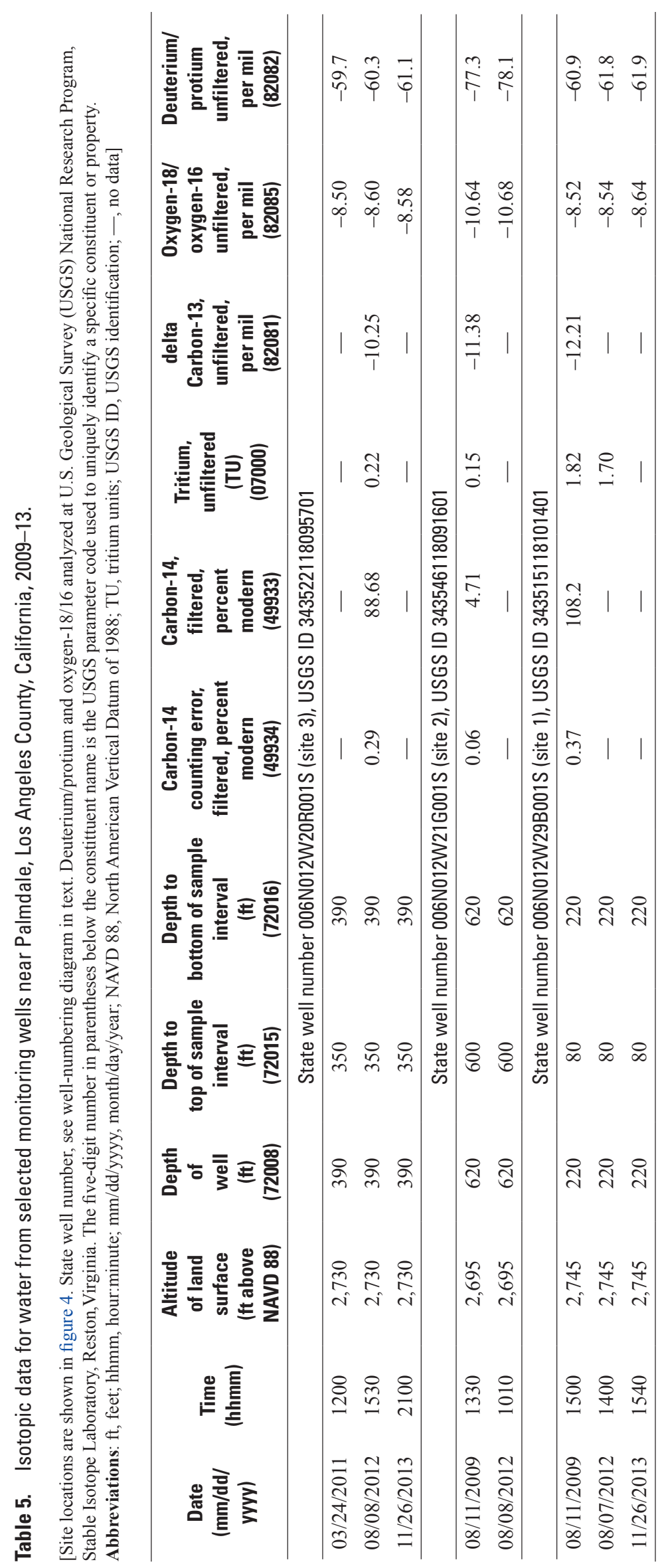


Table 6. Isotopic data for water from selected wells near Palmdale, California, 1997-2013.

[State well number, see well-numbering diagram in text. The five-digit number in parentheses below the constittuent name is the U.S. Geological Survey (USGS) parameter code used to uniquely identify a specific constituent or property. Deuterium/protium and oxygen-18/16 analyzed by USGS National Research Program, Stable Isotope Laboratory, Reston, Virginia. Abbreviations: hhmm, hour:minute; mm/dd/yyyy, month/day/year]

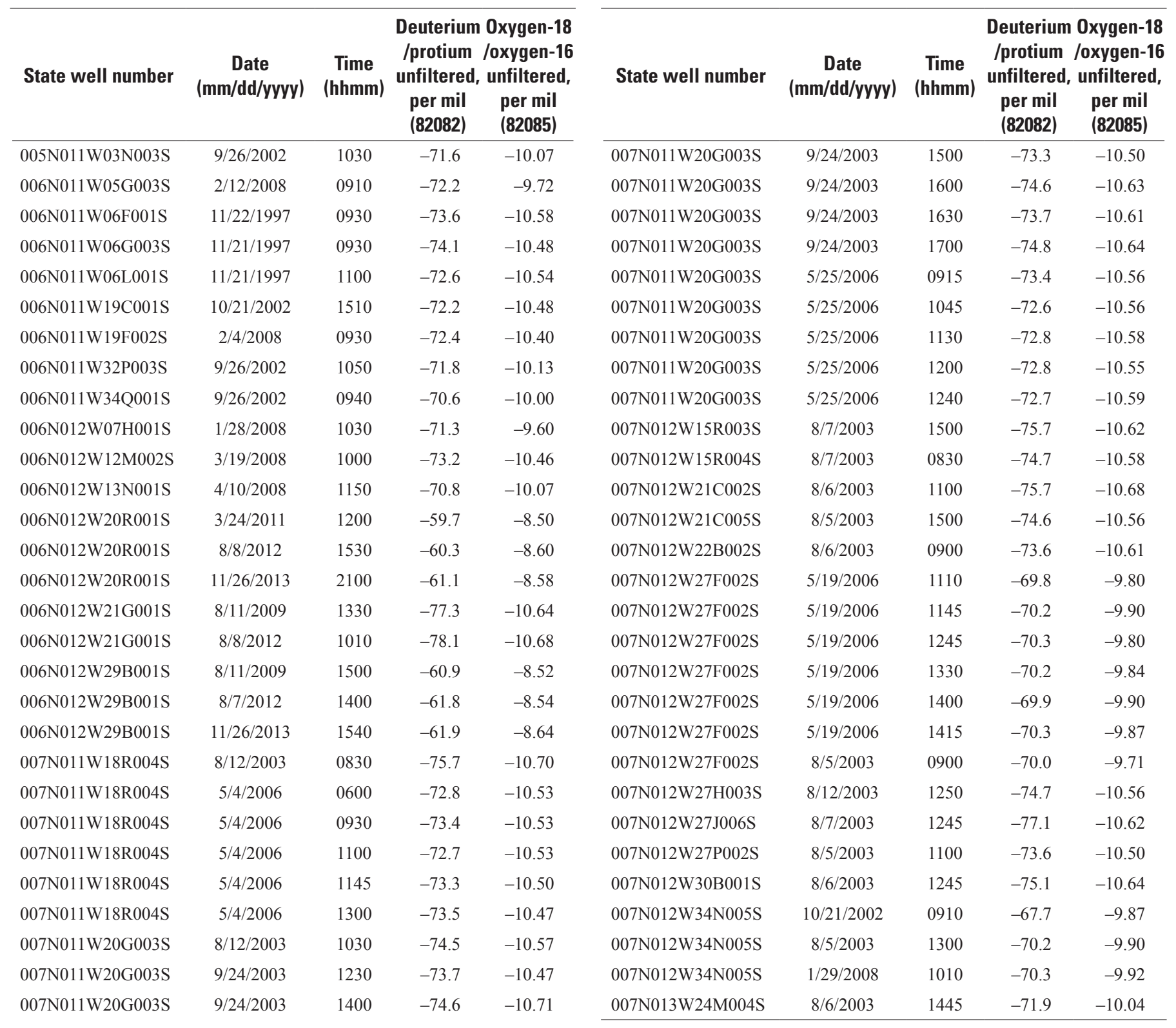




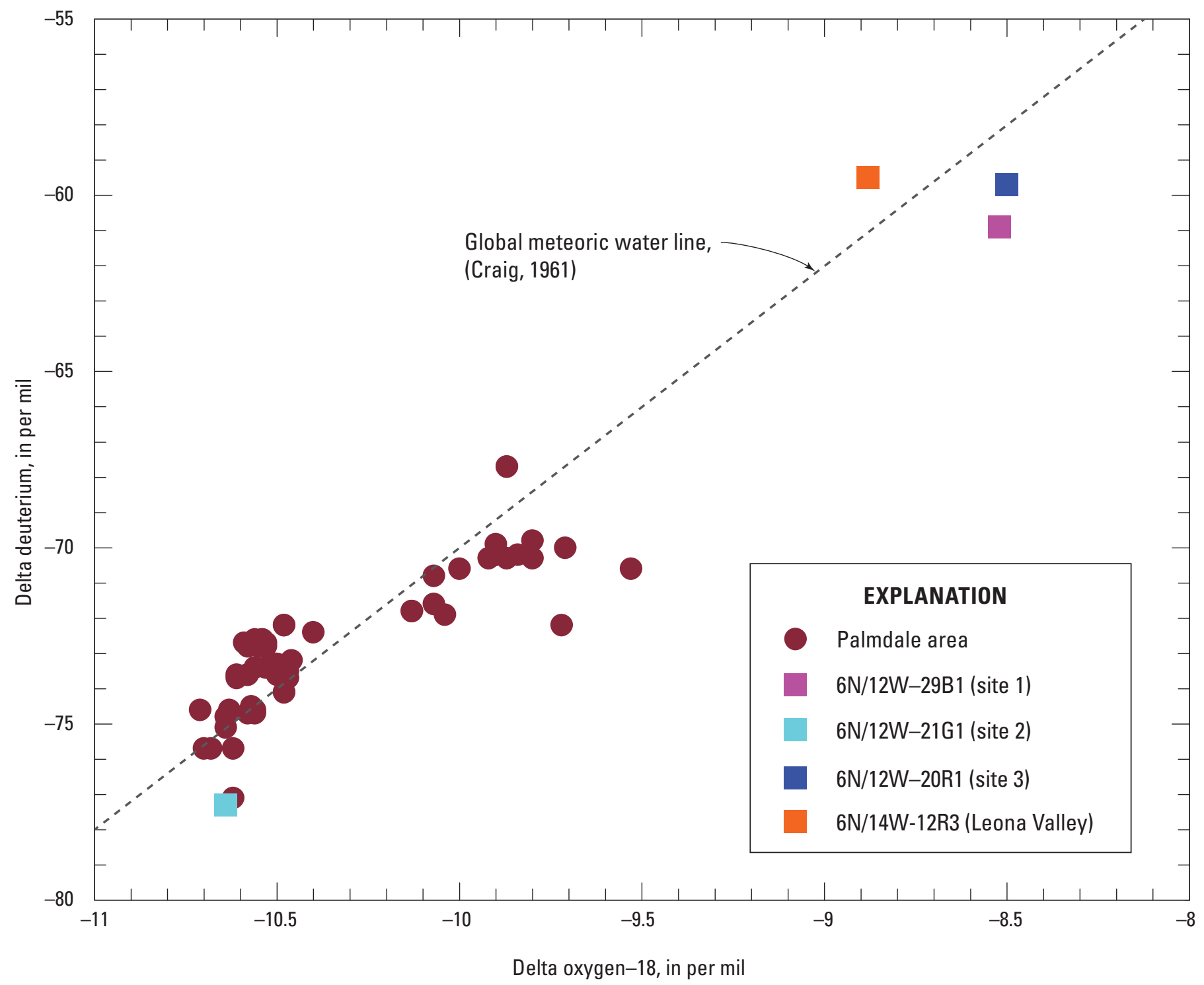

Figure 9. Stable isotope data for samples collected from monitoring sites 1, 2, and 3 and the vicinity of Palmdale, California, 2009-13.

part of the water molecule, and therefore, ${ }^{14} \mathrm{C}$ activities can be affected by chemical reactions that remove or add carbon to solution. In addition, ${ }^{14} \mathrm{C}$ activities are affected by the mixing of younger water that has high ${ }^{14} \mathrm{C}$ activity with older water that has low ${ }^{14} \mathrm{C}$ activity. Carbon-14 ages presented in this report do not account for changes in ${ }^{14} \mathrm{C}$ activity resulting from chemical reactions or mixing and, therefore, are considered uncorrected ages. In general, uncorrected ${ }^{14} \mathrm{C}$ ages are older than the actual age of the associated water. Izbicki and others (1995) estimated that uncorrected ${ }^{14} \mathrm{C}$ ages were as much as 30 percent older than actual ages for groundwater in the regional aquifer in the neighboring Mojave River groundwater basin (not shown), about 40 mi east of the study area.

Carbon-14 values for samples collected at sites 1, 2 (well 21G1), and 3 were $108.2 \mathrm{pmc}, 4.7 \mathrm{pmc}$, and $88.7 \mathrm{pmc}$ respectively (table 5). These ${ }^{14} \mathrm{C}$ activities corresponded to uncorrected ${ }^{14} \mathrm{C}$ groundwater age of less than 50 years for the sample collected at site 1, 25,300 years before present (ybp) at site 2, and $990 \mathrm{ybp}$ for the sample collected at site 3 . The ${ }^{14} \mathrm{C}$ activity at site 3 , however, was within the range of values that could indicate mixing of modern water with ${ }^{14} \mathrm{C}$ activity affected by modern atmospheric nuclear testing with premodern waters; consequently, the ${ }^{14} \mathrm{C}$ values for site 3 do not definitively indicate a modern or pre-modern recharge age. Although each site was in close proximity to the Amargosa Creek, the combination of stable isotopic, tritium, and ${ }^{14} \mathrm{C}$ results indicated that site 1 had modern-day recharge from Amargosa Creek, site 2 had pre-modern recharge not derived from Amargosa Creek, and site 3 had a mixture of modernand pre-modern recharge derived from Amargosa Creek. 


\section{Surface Geophysical Surveys}

In 2009, three surface geophysical surveys were completed to help define the thickness of the valley-fill deposits or depth to the basement complex in the regional study area; to identify possible features, such as faults, that might influence groundwater flow; and to estimate depth to groundwater (fig. 10). A regional gravity survey was completed, and the data collected were used to develop a valley-fill thickness model to estimate alluvial thickness and the associated basement-complex geometry. High-resolution, shallow-depth seismic refraction and reflection surveys were completed along the Amargosa Creek, near the ACRP, to delineate density contrasts associated with individual sedimentary units in the valley-fill deposits and between these deposits and the basement complex. Resistivity surveys were completed along the Amargosa Creek, near the ACRP, to delineate resistivity contrasts associated with coarser- and finer-grained sedimentary units in the valley-fill deposits and between unsaturated and saturated portions of the aquifer system.

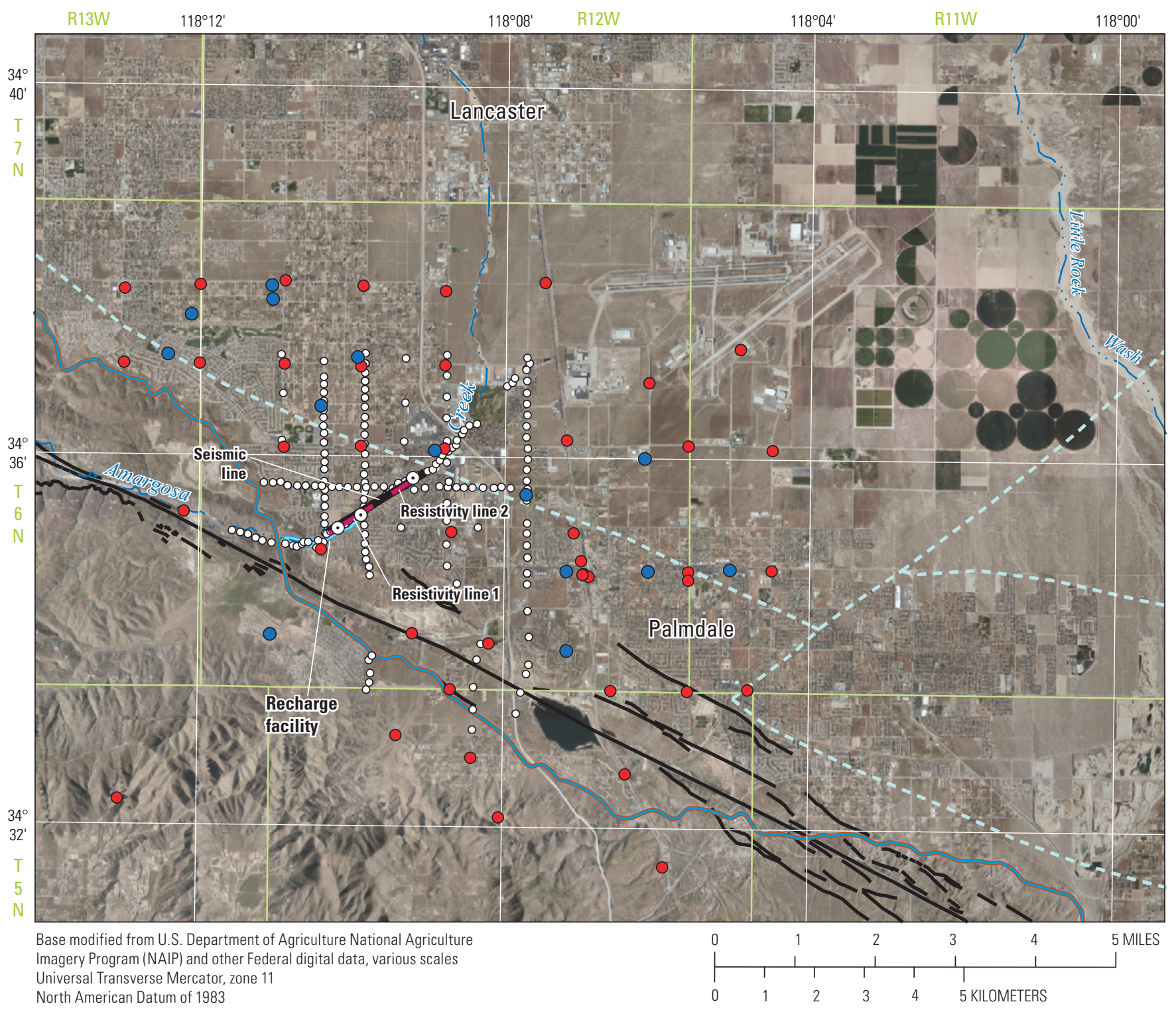

\section{EXPLANATION}

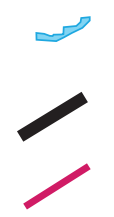

Proposed recharge facility

Seismic line

Resistivity lines 1 and 2
Faults-

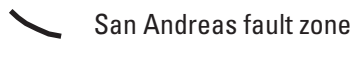

Inferred fault (Bloyd, 1967)

California Aqueduct $\odot \quad$ Monitoring-well site

- Gravity sites from this study

- Regional gravity sites

- Control wells

Figure 10. Location of geophysical surveys, Antelope Valley, California. 


\section{Regional Gravity Survey}

Aeromagnetic data collected by Roberts and Jachens (1999) were examined and used to characterize the nature of the basement rocks at the base of the valley-fill deposits. The valley-fill deposits consist of locally derived Quaternary and Tertiary sediments, which overlay pre-Tertiary metamorphic and crystalline rocks that form the basement complex. Roberts and others (1990) found a large density contrast, averaging 40.6 pounds per cubic foot $\left(\mathrm{lb} / \mathrm{ft}^{3}\right)$ in the upper $650 \mathrm{ft}$, between the valley-fill deposits and the crystalline basement complex, indicating that gravity methods would be appropriate for determining the thickness of the valley-fill deposits.

A gravity survey was completed during this study to define the thickness of the valley-fill deposits, or depth to the basement complex, in the study area. The gravity survey included western Palmdale, southern Lancaster, and the foothills west of the San Andreas fault zone (fig. 10). Gravity data collected for this study were combined with regional gravity data collected by Roberts and others (1990). Gravity measurements made for this study were closely spaced along Amargosa Creek to help determine changes in the basement geometry below the recharge facility and to identify possible features, such as faults, that could influence groundwater flow. Geologic maps and lithologic data from water wells were used to constrain interpretation of the gravity data.

\section{Gravity Survey and Reduction Data Sets}

Gravity measurements were collected at 234 new locations for this study by using a LaCoste and Romberg Model D-79 with Aliod 100 gravity meter (fig. 10). The location and elevation of each gravity measurement was determined by using a Trimble Real Time Kinematic (RTK) Model 4400 Global Positioning System (GPS) base and mobile receivers. This system is capable of obtaining vertical and horizontal coordinates with a precision of plus-or-minus $0.083 \mathrm{ft}$ between receiver and base by using traditional RTK methods described by Morton and others (1993). The RTK survey was referenced to the North American Vertical Datum of 1988 (NAVD 88) by using local bench marks.

The gravity data were reduced by using the Geodetic Reference System of 1967 (International Union of Geodesy and Geophysics, 1971) and referenced to the International Gravity Standardization Net 1971 gravity datum (Morelli, 1974). Gravity data were analyzed using standard gravity corrections, including (1) the earth tide correction, which corrects for tidal effects of the moon and sun; (2) instrument drift correction, which compensates for drift in the instrument's spring; (3) the latitude correction, which incorporates the variation of the Earth's gravity with latitude; (4) the free-air correction, which accounts for the variation in gravity with changes in elevation; (5) the Bouguer correction, which corrects for the attraction of material between the station and the vertical datum; (6) the curvature correction, which adjusts the Bouguer correction for the effect of the Earth's curvature; (7) the terrain correction, which removes the effect of topography to a radial distance of about $104 \mathrm{mi}$
(Telford and others, 1990). Isostatic and terrain correction beyond that distance were interpolated from a grid generated from Karki and others (1961).

Terrain corrections were computed to a radial distance of $104 \mathrm{mi}$ and involved a three-part process: (1) HayfordBowie zones A and B with an outer radius of $223 \mathrm{ft}$ were estimated in the field with the aid of tables and charts from Robbins and Oliver, 1970; (2) Hayford-Bowie zones C and $\mathrm{D}$ with an outer radius of $1,936 \mathrm{ft}$ were computed by using a 100-ft digital elevation model; and (3) terrain corrections from a distance of 1,936 ft to $104 \mathrm{mi}$ were calculated by using a digital elevation model and an established procedure by Plouff (1977). Total terrain corrections for the stations collected for this study ranged from 0.62 to 6.23 milligal (mGal), averaging $1.18 \mathrm{mGal}$; in comparison, corrected isostatic residual gravity values in the study area ranged from about -29 to $+9 \mathrm{mGal}$.

\section{Geologic Maps}

Data from geologic maps were used primarily to delineate the valley-fill deposits from the basement complex outcrops. The geologic maps of Ritter Ridge 7.5-minute quadrangle (Hernandez, 2009) and Palmdale (Olson and Hernandez, 2013) 7.5-minute quadrangles were used for most of the study area, with additional information from the geologic maps of the Del Sur (Hernandez, 2010a), Lancaster West (Hernandez, 2010b), and San Andreas fault zone (Evans, 1978) 7.5-minute quadrangles.

\section{Water Wells}

Fourteen water wells with drillers' logs were available for use as constraints for gravity interpretation (control wells on fig. 10 and table 7). These logs reported materials at the bottom of the drill hole consistent with the basement complex, including sandstone, shale, rock, or granite. Data from sonic logs and depths to the basement complex at monitoring wells completed as part of this study also were used as local basement-complex constraints.

\section{Gravity Field}

The gravity field of the study area (here expressed as the isostatic residual gravity field) primarily reflects the large density contrast between the basement complex and lower density valley-fill deposits (fig. 11). The most prominent features on the gravity maps are the high gravity values (greater than $-5 \mathrm{mGal}$ ) that coincided with shallow alluvium and basement-complex exposures in the San Gabriel Mountains and Ritter Ridge, west of the San Andreas fault zone, and the low gravity values (less than $-10 \mathrm{mGal}$ ) that coincided with thick basin-fill deposits east of the recharge facility in the Antelope Valley. There is a local gravity high, as indicated by the area of greater gravity values (shown in orange), underlying and to the northwest of the proposed ACRP, which was consistent with mapped exposures of quartz-monzonite basement and basement covered with shallow alluvium. 
Table 7. Thickness of alluvial deposits from drillers' logs and gravity surveys for 14 wells near Palmdale, Los Angeles County, California.

[State well number, see well-numbering diagram in text. Abbreviations: DDD MM, degrees decimal minutes; ft, feet]

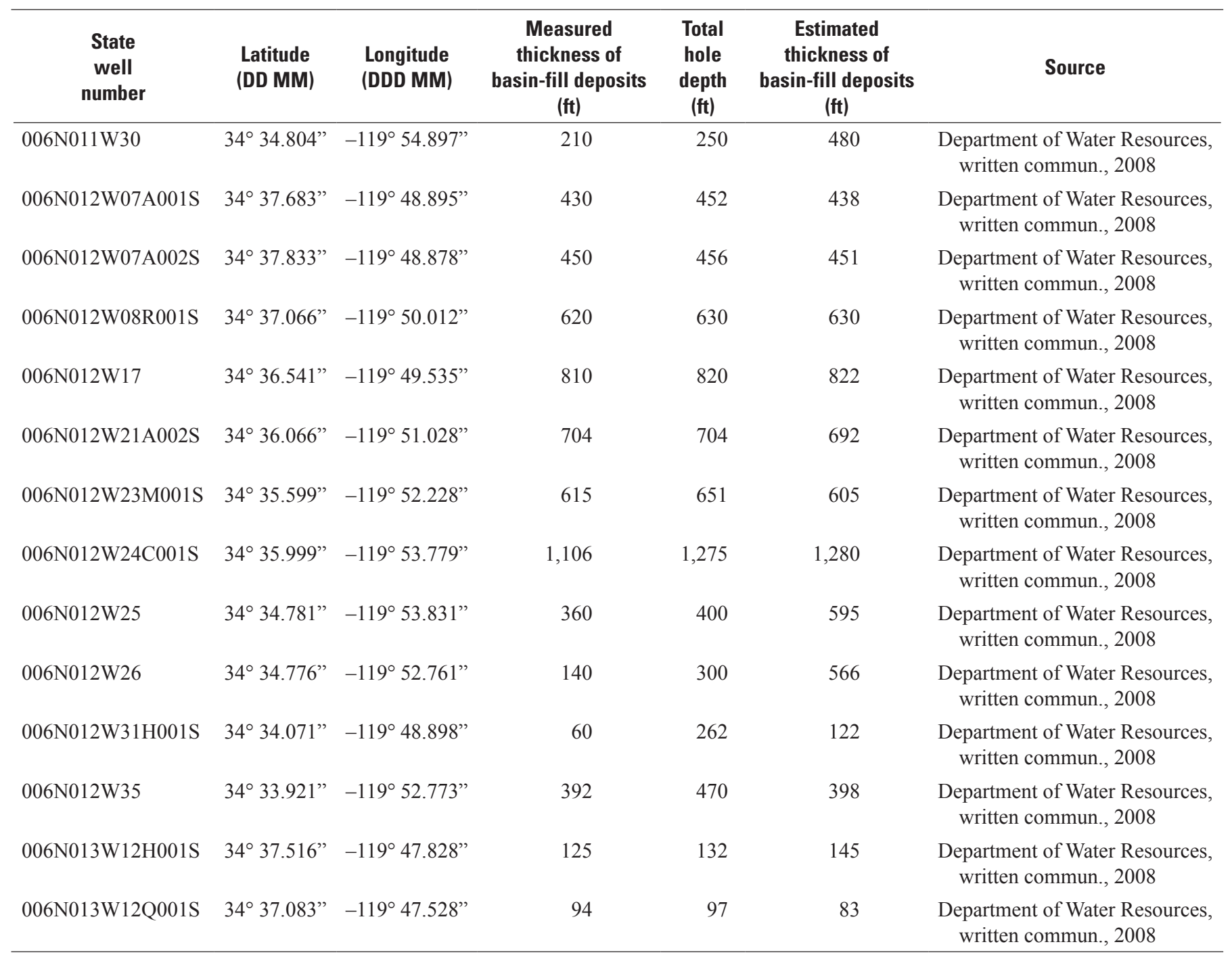




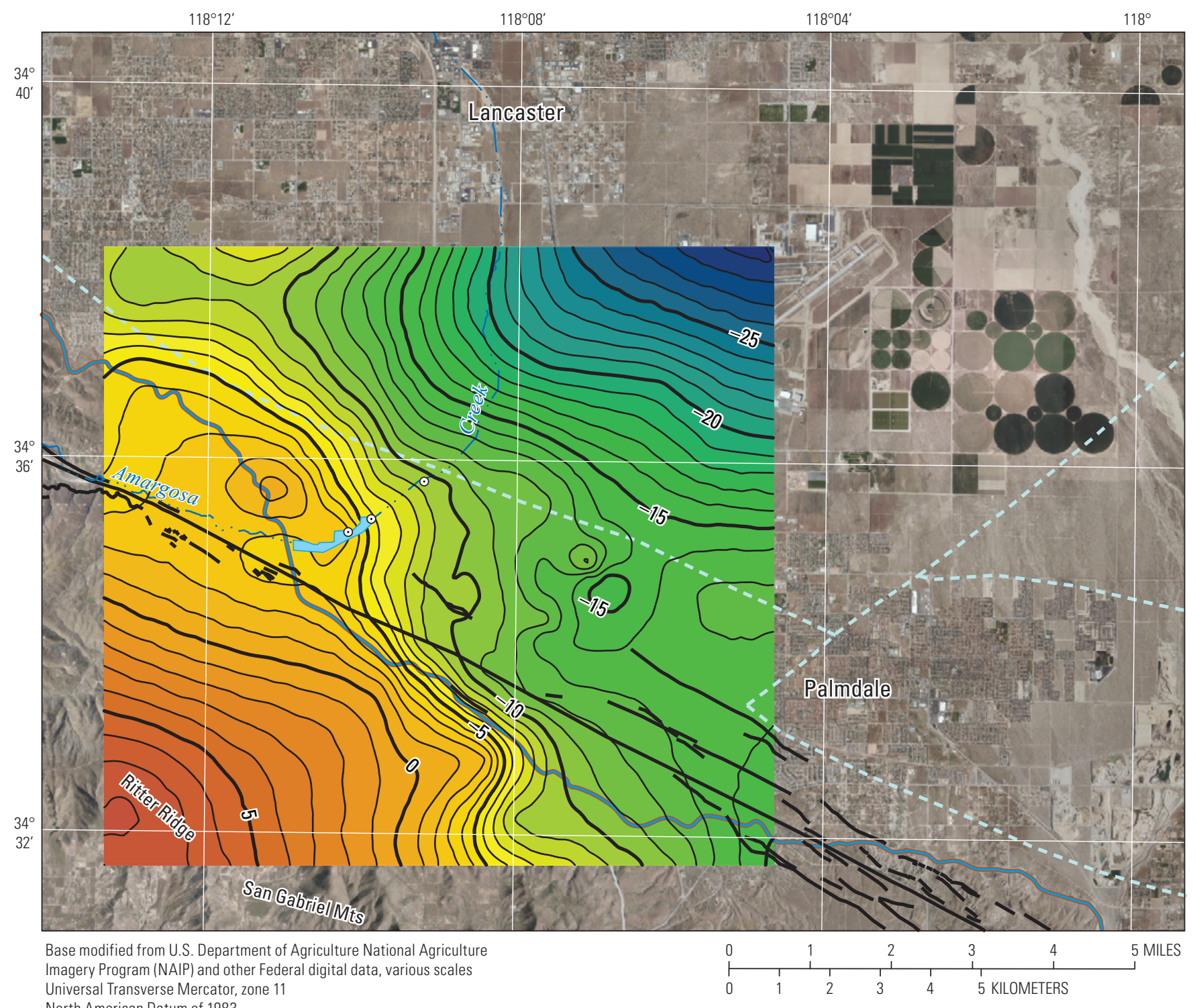

North American Datum of 1983

\section{EXPLANATION}
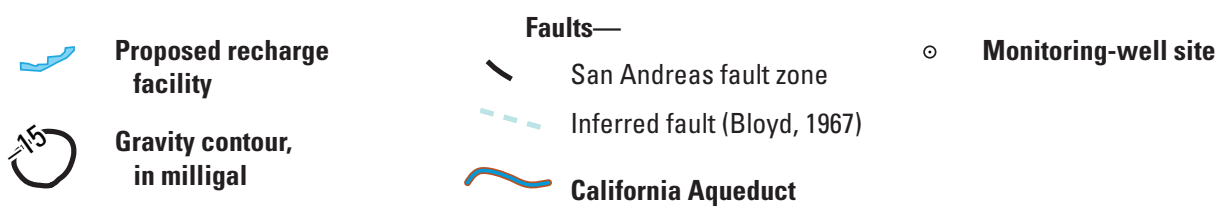

Figure 11. Contoured isostatic residual gravity field, Antelope Valley, California.

\section{Computation Method for Modeling Thickness of Valley-Fill Deposits}

The thickness of the valley-fill deposits (or depth to the basement complex) in the study area was estimated by using the method of Jachens and Moring (1990), modified slightly to permit inclusion of constraints at points where the thickness was known from direct observations in drill holes. An initial estimate of the 'valley-fill deposits gravity anomaly' was made by fitting a smooth surface to the gravity values measured at stations where the basement-complex rocks crop out (initial estimate of the 'basement gravity field') and subtracting this from the isostatic residual gravity field. This represents only the initial estimate because the gravity values at points on the basement complex that lie close to the valley-fill deposits were affected by the lower-density valley-fill deposits and are, therefore, lower than they would be if the valley-fill deposits were not present. To compensate for this effect, the initial 
estimate of the valley-fill deposits gravity anomaly was used to calculate an initial estimate of the thickness of the valleyfill deposits, and the gravity effect of these valley-fill deposits was calculated at all of the basement gravity stations. A second estimate of the basement gravity field was then made by fitting a smooth surface to the basement gravity values corrected by the valley-fill effect; this process was repeated to produce refined estimates of the thickness of the valley-fill deposits until further iterations did not result in notable changes to the modeled thickness of the valley-fill deposits.

The valley-fill deposits gravity anomaly was inverted to estimate the thickness of the valley-fill deposits by using an estimated density contrast that varied with depth (table 8). This density-depth relationship was used for a regional gravity inversion for the Basin and Range province that also included the Mojave Desert (Saltus and Jachens, 1995). The resulting density contrast of $-40.6 \mathrm{lb} / \mathrm{ft}^{3}$ for the valley-fill deposits in the upper $660 \mathrm{ft}$ was reasonable for Quaternary and Tertiary continental deposits overlying pre-Tertiary crystalline rocks. The density contrast was slightly less than that derived from the Banning Pass area approximately 100 miles southeast of the Palmdale (not shown in fig. 1) area along the southern margin of the San Bernardino Mountains, which was $-34.3 \mathrm{lb} / \mathrm{ft}^{3}$ (Langenheim and others, 2005). This density contrast estimation was further verified by examining the basement gravity field for any indications of local anomalies at the sites where wells penetrated the basement.

\section{Gravity Results}

The gravity inversion resulted in a calculated thickness of the valley-fill deposits, or depth to basement complex, that ranged from $0 \mathrm{ft}$ in the San Gabriel Mountains (shown as less than $250 \mathrm{ft}$ on fig. 12) to about $4,700 \mathrm{ft}$ in the northeastern part of the study area. The porosity and permeability of the valley-fill deposits decrease with depth because of compaction and cementation. Therefore, although the depth to basement complex is greatest in the northeastern part of the study area, the thickness of permeable water-bearing deposits likely is much less than the total calculated thickness of valley-fill deposits.

The calculated thickness of the valley-fill deposits where drill holes have penetrated the entire thickness of the valley-fill

Table 8. Estimated density contrast with depth in the Palmdale area.

[ft, feet; $1 \mathrm{~b} / \mathrm{ft}^{3}$, pound per cubic foot; >, less than]

\begin{tabular}{cc}
\hline $\begin{array}{c}\text { Depth range } \\
(\mathbf{f t})\end{array}$ & $\begin{array}{c}\text { Density contrast } \\
\left(\mathbf{l b} / \mathbf{f t}^{3}\right)\end{array}$ \\
\hline $0-660$ & -40.6 \\
$660-2,000$ & -34.3 \\
$2,000-4,000$ & -21.8 \\
$>4,000$ & -15.6 \\
\hline
\end{tabular}

deposits agreed with the observed thickness within $25 \mathrm{ft}$, which was expected because the solution was constrained to honor these values. Basic uncertainties in the gravity data meant that the best resolution that could be expected, even in areas of good gravity coverage, was about $50 \mathrm{ft}$, and resolution was likely to be less in areas of poor gravity coverage or in areas far from either the basement outcrop or control wells. In addition, the calculations were done for grid cells that were $1,000 \mathrm{ft}$ by $1,000 \mathrm{ft}$; therefore, the results represent the average thickness of valley-fill deposits for each cell. Variations of the thickness of the valley-fill deposits over distances less than $1,000 \mathrm{ft}$ were not resolved. Gravity data reflect the average shape of the valley-fill deposits, and the averaging over thicker sections (deeper) from the gravity station. As a result, where the valley-fill deposits are the thickest are subject to averaging over greater volume of material; thus, contours appeared smoother in these areas than in those where the valley-fill deposits are thinner. Finally, the model assumed no lateral variations in density within the valley-fill deposits. This might not be valid if deposits coarsen toward the mountain front.

Analysis of the results from the valley-fill thickness model indicated an alluvial-filled trough in the basement trending northeast is to the north and northeast of the ACRP (fig. 12). The Amargosa Creek channel is generally sub-parallel and south of the trough and then trends north across the trough. The thickness of the valley-fill deposits in the trough increases to the northeast to greater than $3,000 \mathrm{ft}$. Southeast of the ACRP and along the Amargosa Creek channel, the valley-fill deposits thin to less than $250 \mathrm{ft}$, forming a shallow plateau that extends southeast toward Palmdale.

\section{Seismic Refraction and Reflection, and Direct- Current Resistivity Surveys}

As part of this study, the USGS Seismic Imaging Group collected shallow-depth combined seismic reflection and refraction data along the eastern part of ACRP and along Amargosa Creek to help delineate and visualize geologic structures. The approximately 7,400 ft long seismic line extended northeast along Amargosa Creek from a point $250 \mathrm{ft}$ east of Highland Avenue and $600 \mathrm{ft}$ north of Elizabeth Lake Road (fig. 13). In addition to the seismic data collected, directcurrent (DC) resistivity data were collected along two sections of the seismic profile (fig. 13).

\section{Seismic Refraction and Reflection Survey}

Seismic data were acquired in a manner that both allows refraction and reflection images to be produced. First-arrival refractions were inverted for velocity structure, to develop $\mathrm{P}$-wave velocity images along the seismic line, by using a modified version of the tomographic inversion code of Hole (1992). The data were inverted by using a $16-\mathrm{ft}$ by $16-\mathrm{ft}$ grid along the profile to the depth of ray coverage. A firstarrival refraction on each seismogram from each seismic 


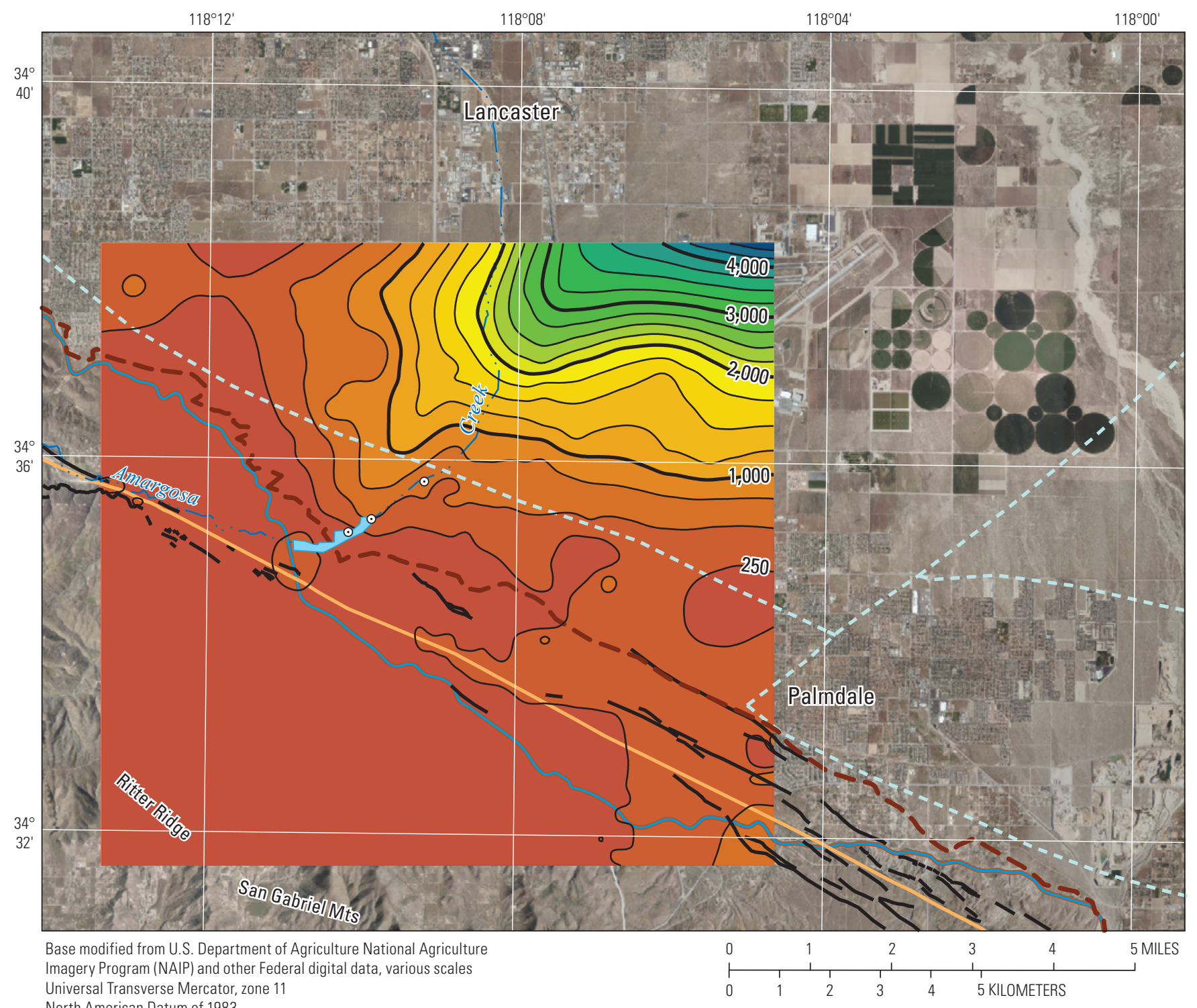

\section{EXPLANATION}

Proposed recharge
facility

Figure 12. Thickness of the valley-fill deposits calculated from gravity measurements in the Palmdale area, Antelope Valley, California. 


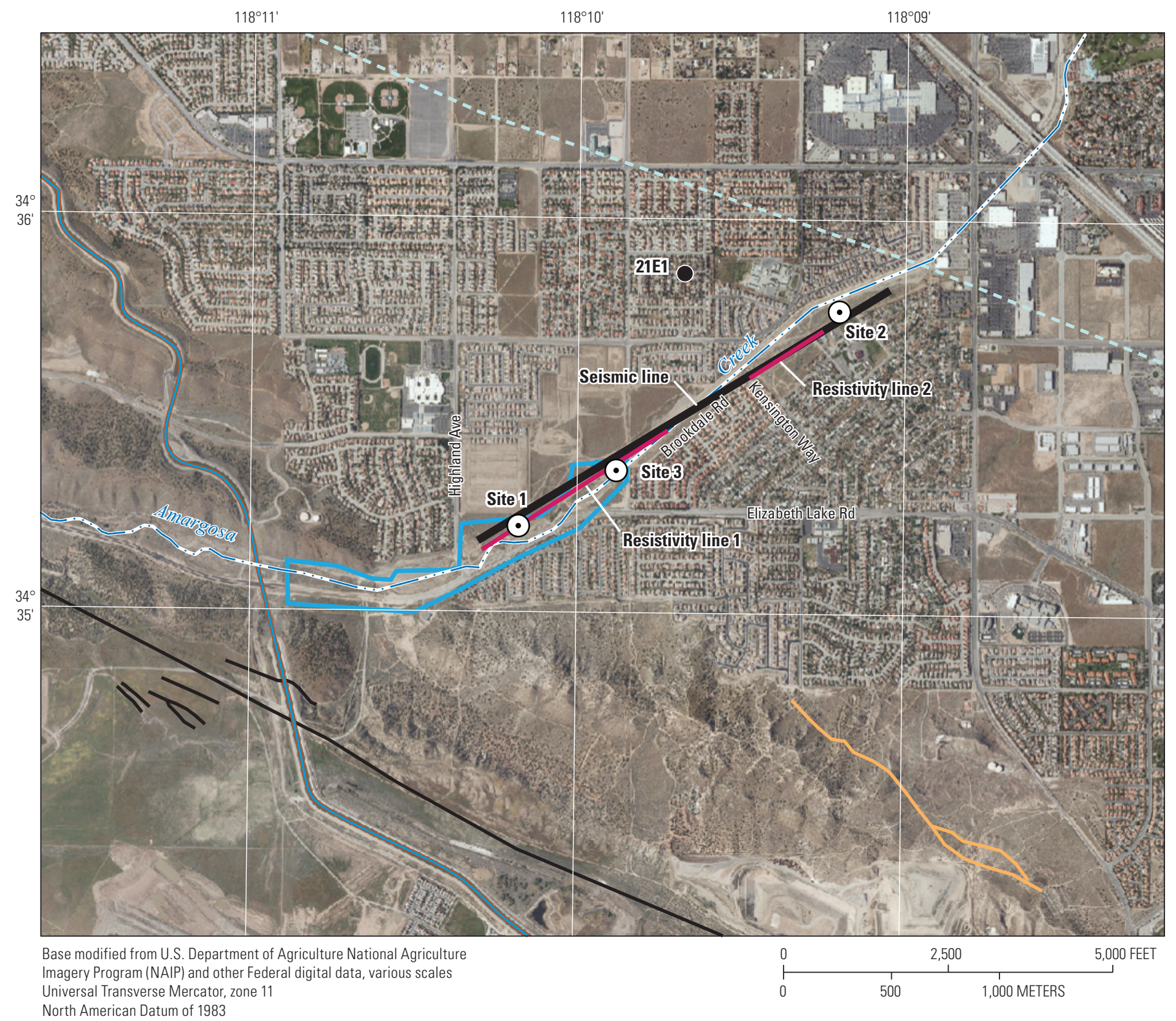

North American Datum of 1983

\section{EXPLANATION}
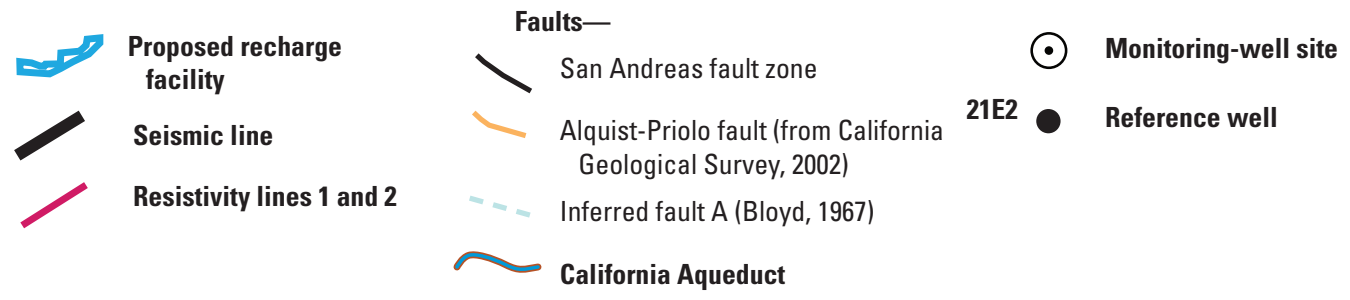

Figure 13. Locations of seismic refraction and reflection surveys and direct current (DC) resistivity surveys along Amargosa Creek near Palmdale, California. 
source was inspected and measured, resulting in a total of 20,295 seismograms. Because of the high level of cultural noise, however, it was not possible to determine first-arrival refractions on all the seismograms, particularly for those far from the shot source.

\section{Seismic Data Acquisition and Processing}

Data were recorded by using a linear array of three Geometrics Strataview ${ }^{\mathrm{TM}}$ RX-60 seismographs, each with 60 active channels. The recorded data were stored on the hard drive of the Strataview computers during field acquisition and later downloaded to 4-millimeter ( $\mathrm{mm}$ ) tape for storage in SEG-Y format (Norris and Faichney, 2001). Forty-hertz (Hz), single-element, Mark Products, L-40ATM geophones were spaced at approximately 33-ft intervals along the profile. Seismic sources (shots), at depths of about $1.5 \mathrm{ft}$, were laterally spaced approximately every $66 \mathrm{ft}$ and co-located (3-ft lateral offset) with the geophones along the approximately 7,400 ft profile. Each recording site and shot point was measured with a tape and flagged to obtain the proper spacing. The shots were generated by a BETSY Seisgun ${ }^{\mathrm{TM}}$ using 8-gauge shotgun blanks. Shot timing was determined electronically at the seismic source when the hammer electrically closed contact with the Seisgun ${ }^{\mathrm{TM}}$, sending an electrical signal to the seismograph. After the seismic data were acquired, the location and elevation of each recording and shot site were determined by using RTK-GPS methods described earlier in this report.

Reflection images were developed by using the seismic data and appropriate reflection processing schemes. The seismic processing procedures used for this study were similar to those outlined by Brouwer and Helbig (1998). Data processing steps included geometry installation, trace editing, timing corrections, elevation statics, muting, Automatic Gain Control, bandpass filtering, velocity analysis, Normal Move Out correction, stacking, depth conversion, and deconvolution. The reflection images were migrated using pre-stack depth migration to properly image complex structures such as dipping layers and abruptly terminated layers. Seismic-reflection images were developed from the seismic data by stacking shot gathers with approximately 180 channels per shot and converting the time sections to depth sections by using the inverted tomographic velocity model (Hole, 1992; fig. 14A). Common Depth Point intervals along the line were $8 \mathrm{ft}$, resulting in a seismic trace every $16 \mathrm{ft}$ (U.S. Environmental Protection Agency, 2011). Several prominent reflectors were observed in the shot gathers within the first few hundred milliseconds, indicating that the seismic energy penetrated more than 1,000 ft in depth. The resolving ability of reflected seismic energy is about one-quarter of a wavelength (Dobrin and Savit, 1988). In theory, for the nearsurface strata with velocities of approximately 2,600 feet per second ( $\mathrm{ft} / \mathrm{s})$, relatively small subsurface structures of $15-30 \mathrm{ft}$ could be imaged with the reflection data.

The range of frequencies that could be used to measure first-arrival refractions was limited because of high attenuation in the sandy soils and high cultural noise levels; the data were filtered at relatively low frequencies $(10,20,40$, and $80 \mathrm{~Hz})$ to maximize the propagation distance of the seismic data. The limited propagation distances of the seismic data allowed accurate P-wave seismic velocity images to be developed only for relatively shallow (approximately $250 \mathrm{ft}$ ) depths (fig. 14B).

\section{Seismic Survey Results}

The reflection image showed a change in reflective character of the strata overlying the depth of the basement complex (pink region in fig. 14A) interpreted from seismic data. The strata above this contact were characterized by multiple prominent reflectors, whereas the strata below the contact were characterized by relatively weak reflectors. This change in reflective character was interpreted to be the contact between valley-fill deposits, combined with weathered or fractured basement, and the unweathered or unfractured basement complex. The unweathered or unfractured basement complex is denser than the overlying material; therefore, much of the seismic energy reflected off of this boundary. The change in reflective character also coincided with increased resistivity in the 64-in. normal-borehole resistivity logs at the depth where bedrock was encountered at sites 1,2 , and 3 . The top of the weathered or fractured basement (sites 1 and 2) and indurated valley-fill deposits (site 3), as noted from geophysical and lithologic logs, were plotted (in red) at well locations along the profile. The change in reflective character and change in apparent dip of reflectors at lateral distances from the southwest origin of the line of 900-1,600 and 5,200-6,000 ft indicated the presence of faults. The seismic refraction image also showed changes in depth of the basement complex at lateral distances of 900-1,600 ft and about 5,200-6,000 ft along the profile, which further indicated the presence of faults.

The P-wave velocity image (fig. 14B) shows the average seismic velocities (averaged over a distance of $33 \mathrm{ft}$ or more) measured from the surface to a maximum depth of about $250 \mathrm{ft}$ bls. The near-surface velocities ranged from about 1,300 to about 2,300 ft/s in the upper $65 \mathrm{ft}$. From about $65 \mathrm{ft}$ to about $250 \mathrm{ft}$ bls, the velocities varied between about 2,600 and $6,600 \mathrm{ft} / \mathrm{s}$. In general, the seismic velocities greater than 4,265 ft/s (fig. 14B) represented more consolidated and saturated sediments. Velocities less than about 4,265 ft/s (fig. 14B) represented unconsolidated and unsaturated materials. Unconsolidated saturated sediments typically have P-wave velocities in excess of 4,920 ft/s, sedimentary rocks have velocities in excess of $7,218 \mathrm{ft} / \mathrm{s}$, and unfractured granitic and metamorphic rocks have velocities in excess of $13,000 \mathrm{ft} / \mathrm{s}$ in the shallow subsurface (Catchings and others, 2009). P-wave velocities representative of unweathered or unfractured basement complex (in excess of 13,000 ft/s) were not measured in the limited-depth model; however, P-wave velocities in excess of $6,000 \mathrm{ft} / \mathrm{s}$ were measured at the base of the southwestern end of the seismic profile. These higher velocities probably reflected the presence of the weathered or fractured basement complex. The 4,921-ft/s velocity contour 
胥

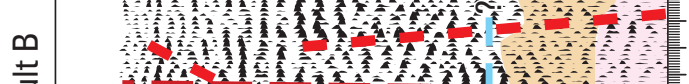
宁

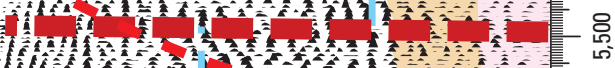

flith

160

(10)

110101010

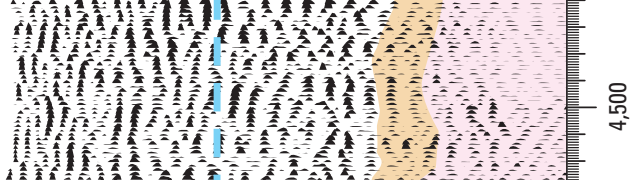

MI)

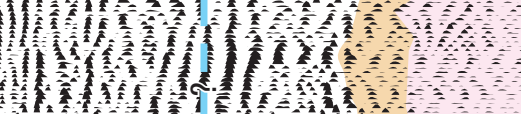

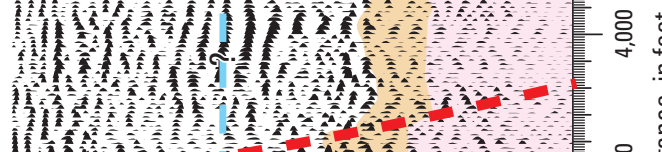

What

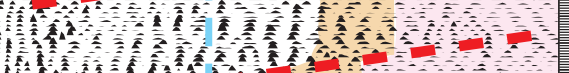

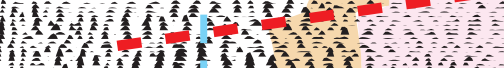

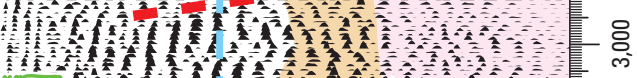

WII 1010

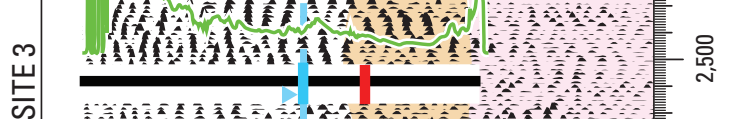

领

mint

With

Matis

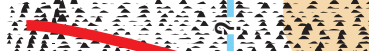

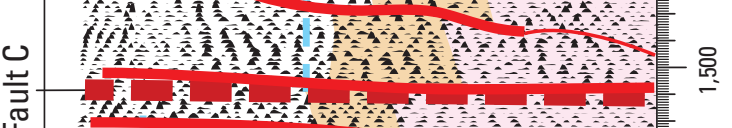

虫

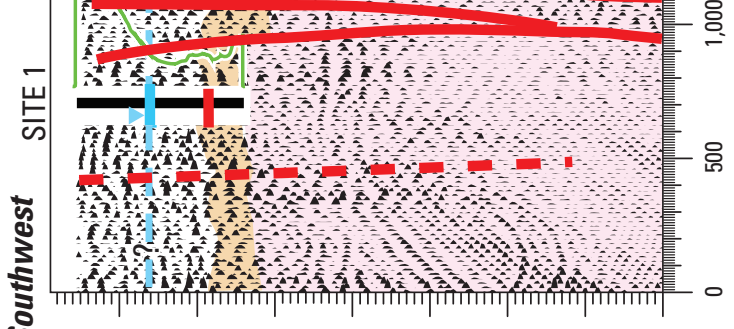

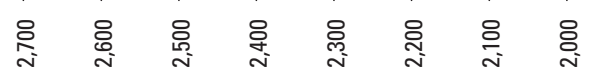

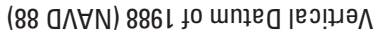

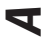

uе ग!ฺәш $\forall$ чน.

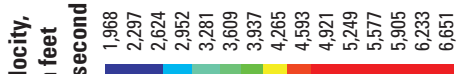

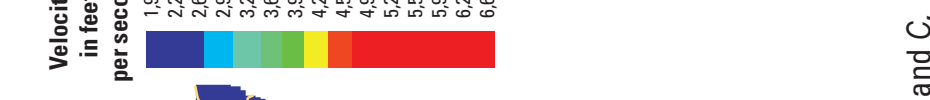

$\stackrel{\oplus}{\Xi}$

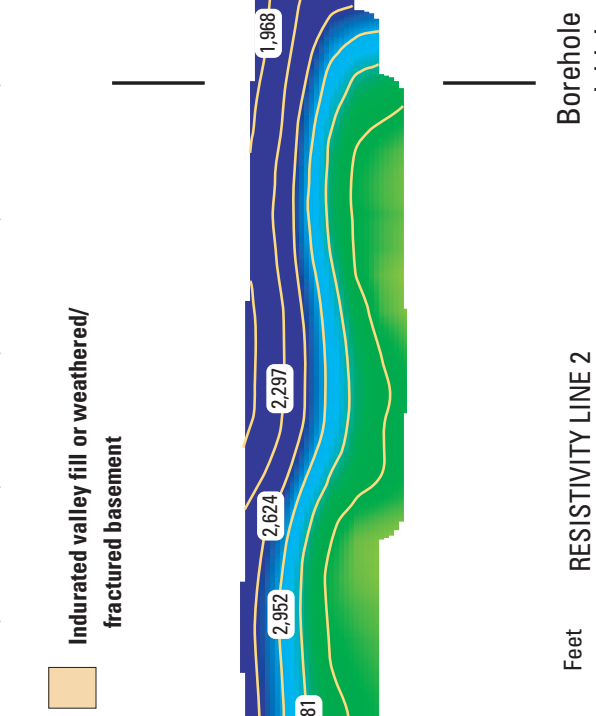

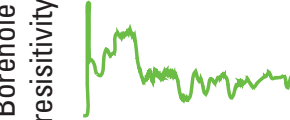

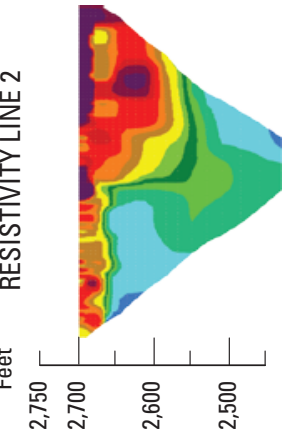

1

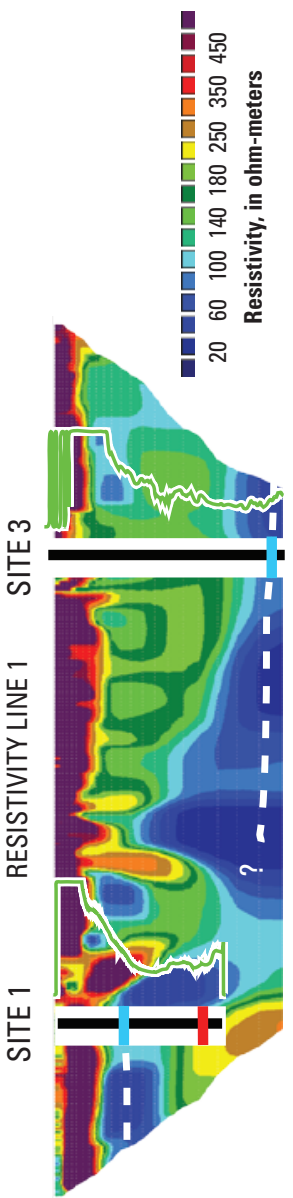

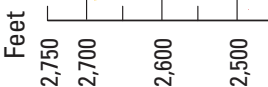

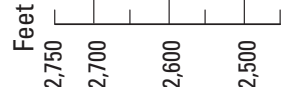

$88 \mathrm{Q \wedge} \forall N$ әлоqе

$88 \mathrm{Q \wedge} \forall N$ әлоqе

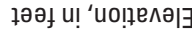

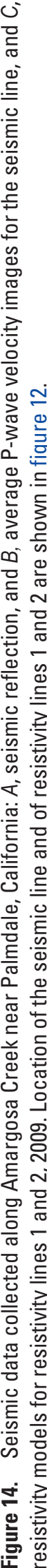


(fig. 14B) coincided with the measured depth of groundwater at site 1 (about $103 \mathrm{ft}$ bls). The depth to the 4,921 ft/s contour (water table) increased from about $100 \mathrm{ft}$ bls at site 1 to about $250 \mathrm{ft}$ bls at about 1,700 ft lateral distance from the west end of the line. Northeast of this point, the 4,921-ft/s velocity contour was below the depth imaged by the velocity model, indicating that the depth to groundwater was in excess of $250 \mathrm{ft}$ bls, which coincided with available water-level data shown in figures $14 A$ and 7.

The P-wave velocity image showed increases in the depth of high-velocity basement between lateral distances of 900 to $1,400 \mathrm{ft}$ and at 5,250 to $6,000 \mathrm{ft}$ along the profile, (fig. 14B). The low-velocity sediments are approximately $150 \mathrm{ft}$ thick from lateral distances of 0 to about $1,000 \mathrm{ft}$, greater than $150 \mathrm{ft}$ thick from lateral distances of about 1,000 to about $5,250 \mathrm{ft}$, and greater than $400 \mathrm{ft}$ thick from about 5,250 $\mathrm{ft}$ to the end of the profile (fig. 14B). The changes in thickness of the lowvelocity sediments could be due to increased deposition of alluvium on the downthrown side of faults.

\section{Resistivity Surveys}

In addition to the seismic data, DC resistivity data were collected along two sections of the seismic profile (fig. 13). Resistivity data were collected along line 1, a 3,300-ft transect, and line 2, a 1,200-ft transect.

\section{Resistivity Data Acquisition}

The DC resistivity measurements were made by injecting a known current into the subsurface through two "transmitter" current electrodes and measuring the resulting voltage difference between two "receiver" electrodes. In two-dimensional resistivity surveys such as this one, an array of electrodes spaced at regular intervals is placed into the earth and many different combinations of transmitting and receiving electrode pairs are used to determine apparent resistivity of the earth beneath receiving electrode pairs. Information about lateral variability in the subsurface is gained as the measuring electrode pairs are shifted across the array, whereas information about greater depths is obtained by increasing the separation between electrodes. Details about the practical aspects of resistivity surveying techniques can be found in various texts (for example, Telford and others, 1990; Reynolds, 1997; and Binley and Kemna, 2005).

For this survey, a dipole-dipole array was used, which allows for rapid data acquisition and provides a good balance between lateral and depth resolution. With this geometry, the four electrodes used for each measurement are spread out across the line. The receiver electrodes are closely spaced and remote from the transmitter electrodes, which are also close together (Telford and others, 1990). For each pair of current electrodes, up to eight pairs of potential electrodes are used to gain depth information. For logistical purposes, 14 electrodes are attached to a single cable, then 4 individual electrode cables are strung together to make up the desired line length. Each cable interfaces with the resistivity meter through a switch box. An initial array of 56 electrodes was laid out for each line. Electrodes were set in the earth at 26.25-ft intervals. The length of each line in this survey exceeded the total length of the 4 electrode cables (1,470 ft), requiring a continuous profile, also known as a "roll-along" profile, to be collected by moving a group of 14 electrodes from the start of the line to the end. The depth of investigation is calculated on the basis of the electrode spacing during the inversion process. An apparent resistivity value, which refers to the homogeneous earth resistivity that produces the measured data, is calculated for each point from the injected current, measured voltage, and electrode geometry. Images of the data presented in this form are called pseudosections; they are a conventional way to show the data, but do not represent the true spatial distribution of resistivity values within the earth (Minsley and others, 2009).

Resistivity data were collected by using an Advanced Geosciences Incorporated (AGI) SuperSting R8, 8-channel multi-electrode resistivity meter. This instrument can collect up to eight readings for each current injection. For this survey, transmitted currents were between 0.5 milliamp $(\mathrm{mA})$ and $300 \mathrm{~mA}$, with an average current of $50 \mathrm{~mA}$ and a standard deviation of $0.07 \mathrm{~mA}$. The relatively low injectedcurrent levels are typically used in highly resistive desert environments (Minsley and others, 2009). Measurements were made over a period of 1.2 seconds, during which the polarity of the current electrodes was reversed in order to minimize electrode polarization effects and to improve contact resistance.

\section{Resistivity Data Processing}

Forward and inverse modeling are mathematical techniques that are used to generate a subsurface-resistivity model from measurements of the injected current, the voltage at the receiver electrodes, and the down-line locations of the four electrodes used for each measurement. Forward modeling refers to the process of predicting the data that would be measured from a given resistivity model and is based on the physics of electrical current flow in resistive media. The forward-modeling process is well-posed; that is, there is a unique set of predicted data for a given resistivity model. Inverse modeling refers to the derivation of a resistivity model from the measured data. The inverse-modeling process is nonunique, that is, there are many models that are consistent with the measured data. To overcome nonuniqueness, additional user-specified constraints are placed on the model, such as requiring it to be smooth, similar to a reference model, or both. These additional constraints often incorporate reasonable a priori geologic information and produce more stable inversion results. A detailed discussion of the resistivity inverse problem is widely available (for example, Oldenburg and Li, 1994; Zhang and others, 1995; Loke and Barker, 1996; and Binley and Kemna, 2005).

The data were inverted by using the Geotomo Software RES2DINV version 3.59.104 (Geotomo Software, 2009, http://geotomosoft.com) that uses the "robust" inversion method, which performs well on noisy datasets because it 
is based on the assumption that data errors are distributed exponentially. The inversion process seeks to find the subsurface distribution of resistivity values that (1) produce modeled data that match the measured data within an acceptable tolerance, (2) satisfy constraints that the model is both smooth and similar to a user-specified reference model and (3) is as simple as possible (Geotomo Software, 2009, http://geotomosoft.com).

Inversions start from a homogeneous resistivity model (simplest possible) and then are iteratively updated to produce more complex heterogeneous models that reduce data misfit. The inversions were allowed to run for a maximum of 10 iterations, with stopping criteria of 6 percent or less root-mean-square (RMS) error between the measured and forward modeled data or an L2-norm (sum of squares) value of one or less for the error-weighted data misfit. If neither of the stopping criteria are met after reaching the end of the tenth iteration, noise in the data is reduced by eliminating measurements that have the poorest data fit. Multiple inversions were run with various reference models, data errors, and smoothing parameters in order to get a sense for the robustness, or stability, of the model results (Minsley and others, 2009).

\section{Resistivity Survey Results}

In general, resistivity values greater than $200 \mathrm{ohm}$-meters (ohm-m; fig. 14C) represented unsaturated sediments and bedrock, and resistivity values less than $200 \mathrm{ohm}-\mathrm{m}$ (fig. 14C) represented saturated sediments or unsaturated sediments with higher moisture content. The resistivity values less than approximately $40 \mathrm{ohm}-\mathrm{m}$ coincided with the measured depth of groundwater of $103 \mathrm{ft}$ and $275 \mathrm{ft}$ bls at sites 1 and 3, respectively (fig 14C). The high-resistivity values in the upper $50 \mathrm{ft}$ of Lines 1 and 2 were consistent with unsaturated sands and gravels described in lithologic logs and measured in the downhole geophysical logs for sites 1, 2, and 3. Resistivity values in two zones, between lateral distances of $700 \mathrm{ft}$ and about 1,400 ft (Line 1) and between 5,400 and 5,600 ft (Line 2) along the profile, increased with depth across these zones, indicating vertical offset in the alluvium. Resistivity values indicative of saturated conditions (less than $40 \mathrm{ohm}$ $\mathrm{m})$ were also offset across the lateral zone between $700 \mathrm{ft}$ and about $1,400 \mathrm{ft}$, indicating depth to water increases between site 1 and site 2 . These offsets in alluvium and water level coincided with interpreted seismic faults and further supported the location of two fault zones along Amargosa Creek: fault C between sites 1 and 3 and fault $\mathrm{B}$ between sites 3 and 2 along the profile (fig. 14A).

\section{Summary of Geophysical Surveys}

The regional and local gravity data provided details of the subsurface topology in the study area, showing an alluvialfilled trough trending northeast from the ACRP, a buried basement ridge that trends north toward western Lancaster, and a buried plateau extending southeast of the ACRP toward
Palmdale (fig. 12). Shallow-depth seismic refraction and reflection and resistivity surveys were completed along the Amargosa Creek to help delineate and visualize geologic structures that could affect groundwater flow. Consistent with observations from monitoring wells, the seismic velocity images indicated that the water table was in the upper 100 $\mathrm{ft}$ of sediments west of fault $\mathrm{C}$, at a depth of about $275 \mathrm{ft}$ east of fault C, and at a depth of about $470 \mathrm{ft}$ east of fault B. The seismic and resistivity data indicated that the basement complex is about $200 \mathrm{ft}$ bls west of fault $\mathrm{C}$. The seismic data indicated depth to basement ranges from approximately 500 to $600 \mathrm{ft}$ bls between Faults $\mathrm{C}$ and $\mathrm{B}$ and increases to greater than $600 \mathrm{ft}$ east of fault B, which was similar to the gravitycalculated depth to basement complex. The seismic reflection images identified major disruptions in the basement interpreted as faults, which were not evident in the regional-gravity data because of the smoothing that resulted from averaging within cells that had 1,000-ft dimensions.

\section{Geohydrologic Structure beneath the ACRP and Vicinity}

A generalized geologic section was completed on the basis of the work of Leighton and Phillips (2003; fig. 3) and by using geophysical, drilling, and monitoring data collected as part of this study and using information from nearby wells (figs. 15 and 16).

For purposes of this study, the geologic units were generalized into pre-Tertiary igneous weathered and crystalline basement complex and Tertiary sedimentary units. Drill-cutting materials collected from the bottom of the holes during drilling of the monitoring sites consisted of pre-Tertiary weathered and crystalline quartz monzonite in the vicinity of the ACRP (figs. 5, 6, and 7).

Sedimentary deposits in the study area were grouped into five major sedimentary units: (1) continental sedimentary deposits (confined-lower aquifer), (2) very old lacustrine deposits (confining unit), (3) very old alluvial valley deposits (unconfined middle aquifer), (4) old alluvial valley deposits (unconfined-upper aquifer), and (5) young alluvial fan deposits (unsaturated; fig.16). These subdivisions reflect fundamental differences in porosity and permeability between the different deposits.

The geologic section also shows the location of three inferred faults: Faults A, B, and C (fig. 16). Fault A was inferred by Bloyd (1967) and is approximately 7,500 ft northwest of the ACRP. Fault B is a previously unmapped fault that is approximately $2,500 \mathrm{ft}$ northwest of the ACRP. This fault location was based on water-level differences between sites 3 and 2 and geophysical data collected as part of this study. Fault $\mathrm{C}$ is also a previously unmapped fault that was located on the basis of water-level differences between site 1 and site 3 and geophysical data collected as part of this study. Fault $\mathrm{C}$ could be an extension of a previously mapped fault (California Geological Survey, 2002) approximately $1 \mathrm{mi}$ southeast of site 1 (fig. 13). 


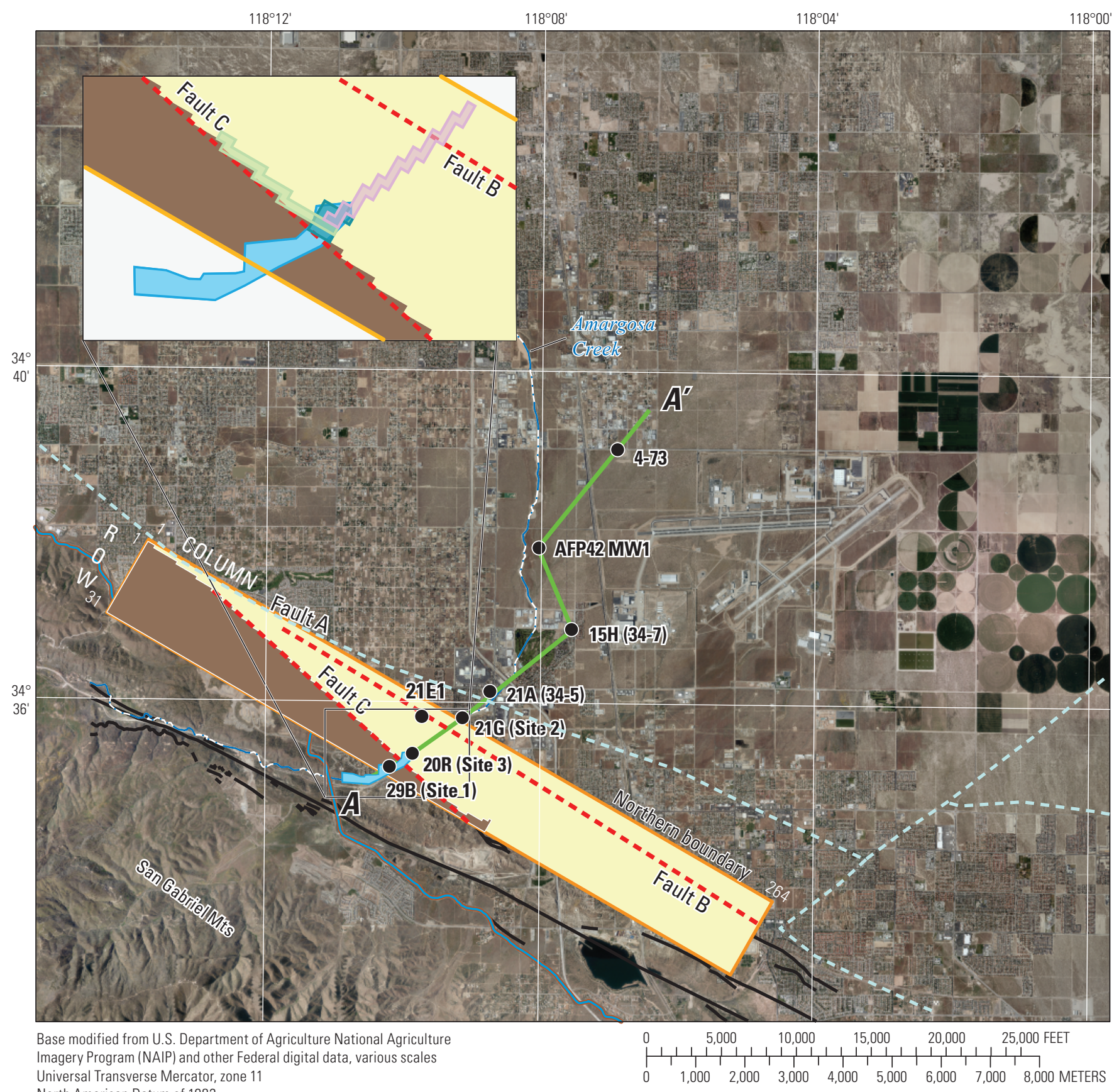

Universal Transverse Mercator, zone 11

North American Datum of 1983
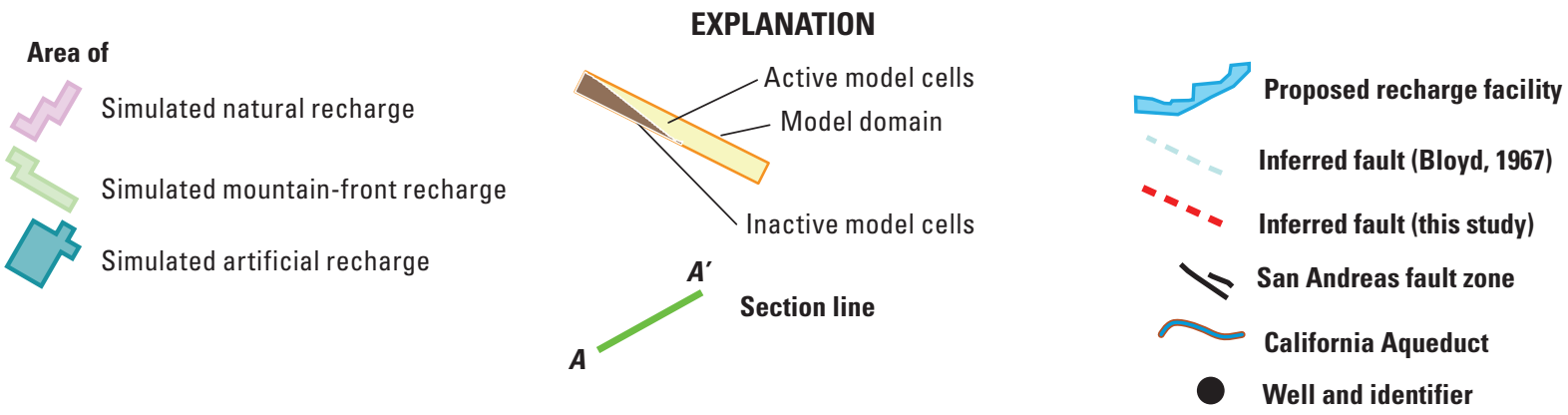

Figure 15. Line of section, model domain, model boundary location, type of boundary and location of Amargosa Creek Recharge Project, Antelope Valley, California. 


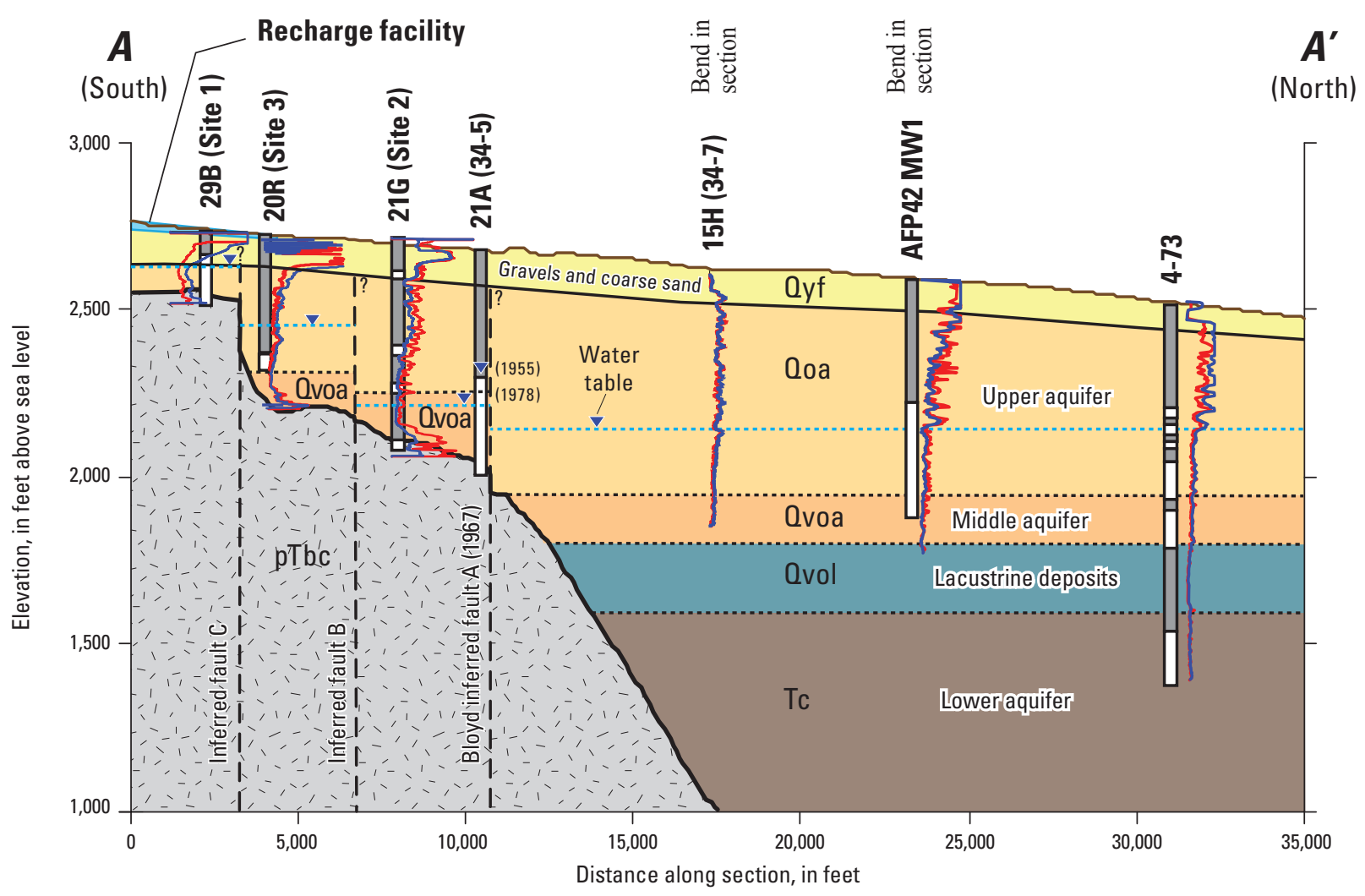

EXPLANATION

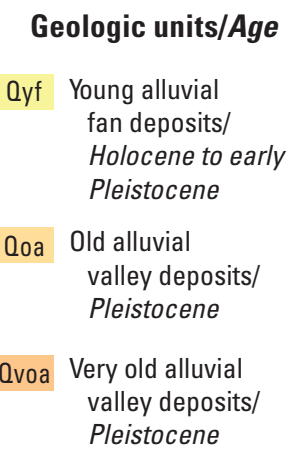

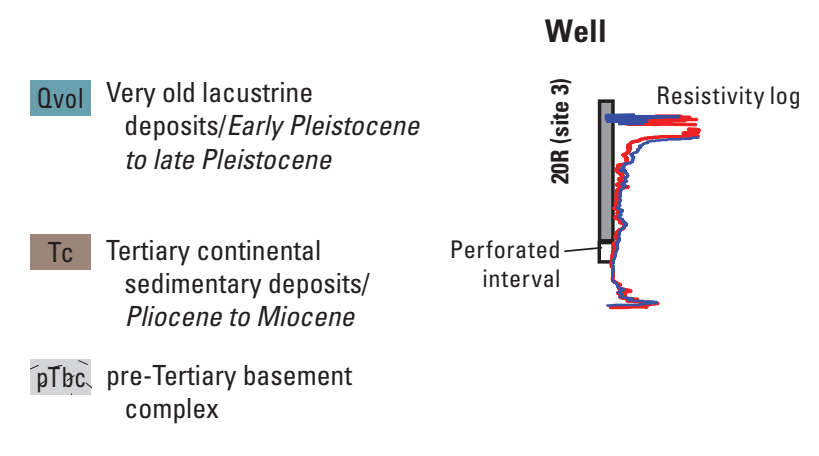

Figure 16. Generalized geologic cross section for the Palmdale and Lancaster area, Antelope Valley, California.

\section{Groundwater-Flow Models}

Two numerical groundwater-flow models were developed to simulate the groundwater-flow system and the potential hydraulic effects of artificial recharge of imported water at the ACRP. The first, the local model, is a local-scale steadystate and transient model designed to determine if fault B is a barrier to groundwater flow and to estimate the fault conductance. The second model, the extended model, is a transient simulation designed for scenario-testing to estimate the maximum recharge flux that can be applied at the ACRP. Both models were developed on the same model grid and simulated aquifer properties.
The models were developed by using the MODFLOWNWT formulation for MODFLOW-2005 (Niswonger and others, 2011). MODFLOW-NWT uses a finite-difference approach to simulate constant-density groundwater flow in three-dimensional heterogeneous porous medium (Harbaugh, 2005). The main difference between MODFLOW-2005 (Harbaugh, 2005) and MODFLOW-NWT is that the latter includes a Newton-type solver that allows a numerically stable simulation of drying and rewetting conditions (Niswonger and others, 2011).

The MODFLOW-NWT packages used in these models included Basic (BAS6), Discretization (DIS), Upstream Weighted Package (UPW), Recharge (RCH), Specified 
Time-Variant Head (CHD), and Well (WEL) Packages. The system solver in MODFLOW-NWT was used both for steadystate and transient simulations (Niswonger and others, 2011).

\section{Local Model: Evaluation of Fault B}

The local model was constructed to help determine if fault $\mathrm{B}$ is a barrier to groundwater flow and to estimate fault properties using both steady-state and transient simulations.

\section{Spatial Discretization}

The local model domain, designed for steady-state model calibration and transient simulation to determine properties of fault B, covers approximately $11.7 \mathrm{mi}^{2}$ along Amargosa Creek (fig. 15). The southwestern boundary is sub-parallel to the San Andreas fault zone, about $0.1 \mathrm{mi}$ southwest of site 1 (fig. 15). The northern boundary is parallel to the southwest boundary, about $200 \mathrm{ft}$ southwest of site 2 and about $1.2 \mathrm{mi}$ northeast of the southwest boundary. The other two boundaries are perpendicular to these boundaries and about $5 \mathrm{mi}$ from where Amargosa Creek enters the southwestern model boundary. The region southwest of the inferred fault $\mathrm{C}$ was not simulated because of the limited unsaturated storage available for artificial recharge.

The active area of the local model (fig. 15) included alluvial valley deposits (Qoa and Qvoa, fig. 16). Because the younger alluvial fan deposits (Qyf, fig. 16) were above the water table in the solution, this unit was not included in the simulation. The local model consisted of one model layer because groundwater flow was assumed to be primarily horizontal through the old alluvial valley deposits (Qoa and Qvoa, layer 2 in fig. 17). The model domain was discretized into a 31 -row by 264-column grid having $200-\mathrm{ft}$ by-200 ft computational cells (fig. 15). Land-surface elevation for the top of the model was extracted from 10-meter (m) National Elevation Dataset (Gesch, 2007) data at model-cell centers. The resulting land-surface elevations in the model domain ranged from about 2,840 ft along the foothills west of Palmdale and along Amargosa Creek to about 2,700 ft along Amargosa Creek at the northern boundary (fig. 17, note that
$\boldsymbol{A}$

(South)
$A^{\prime}$

(North)

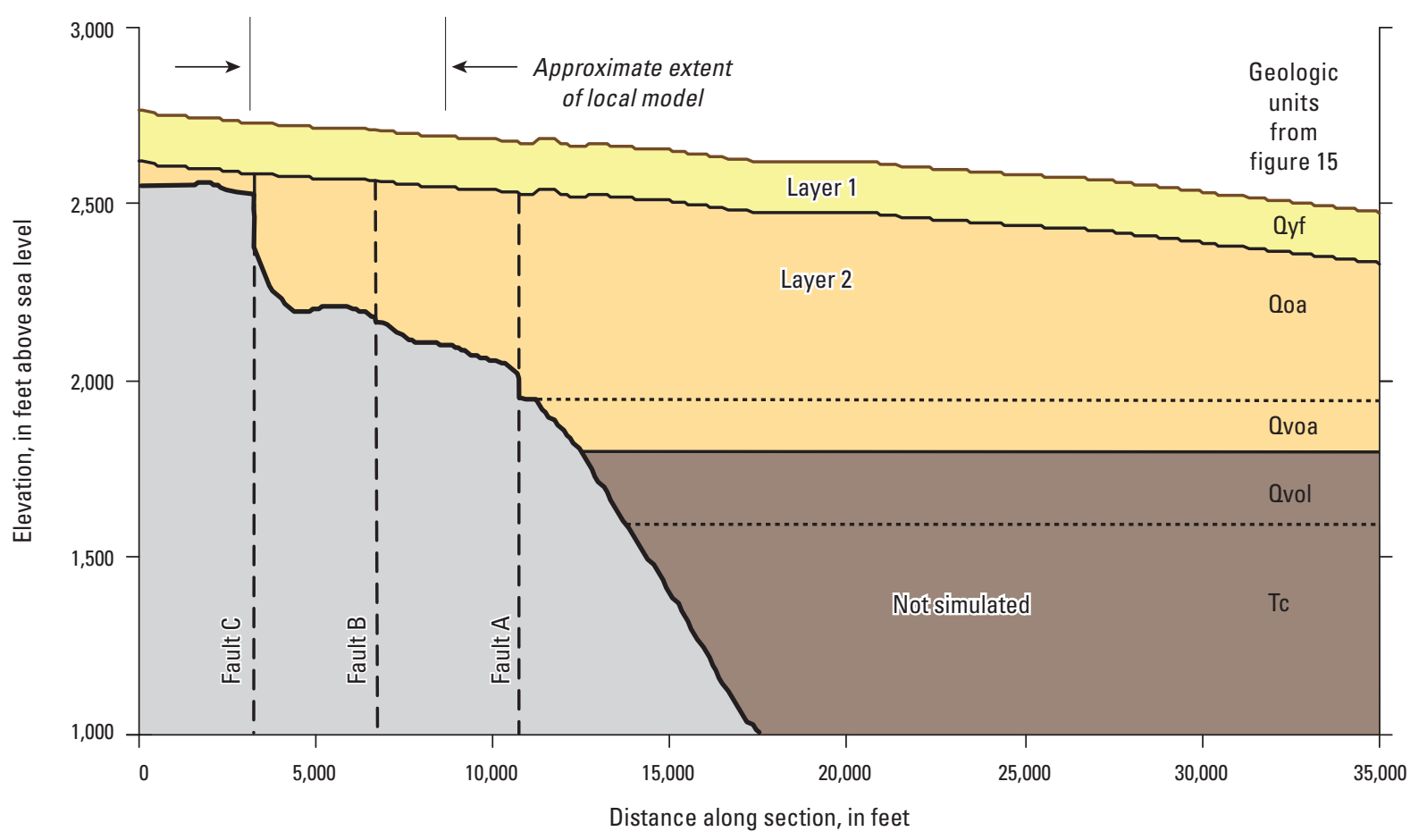

EXPLANATION

\begin{tabular}{|c|c|}
\hline Model units & Not simulated \\
\hline Layer 1 & pre-Tertiary basement \\
\hline Layer 2 & complex \\
\hline
\end{tabular}

Figure 17. Simplified geologic cross section used for model simulations beneath the Amargosa Creek Recharge Project and vicinity, Antelope Valley, California. 
the simplified geologic section shown on figure 16 is A-A' shown on figure 15). The bottom elevation of the model domain was assumed to be the bedrock complex indicated by the valley-fill thickness model and by data collected from construction of the monitoring sites (figs. 16 and 17). The bottom elevation of the active model domain varied from about 2,200 ft along Amargosa Creek at the northeastern boundary to $2,700 \mathrm{ft}$ along the southwestern boundary near the mountain front (fig. 17). The thickness of the model ranged from about $100 \mathrm{ft}$ along the mountain-front of the western active boundary to about $550 \mathrm{ft}$ along the Amargosa Creek at the northeastern boundary.

\section{Temporal Discretization}

Model simulation and calibration of the local model was done using combined steady-state and transient simulations to evaluate fault B. The steady-state simulation represented historical (pre-1924) pre-development conditions. The resulting steady-state hydraulic head distribution was used as an initial condition for a transient simulation that extended from 1924 to 2010 and used annual stress periods.

\section{Model Boundaries}

The local model contained two types of boundary conditions: specified flux and specified head. Specified-flux boundaries represent stream and mountain-front recharge, and no-flow boundaries are where zero-flux conditions exist (fig. 15). The specified-head boundary was based on observed water levels in wells in the Palmdale area.

\section{Specified-Flux Boundaries}

Natural mountain-front recharge was assumed to be constant during the steady-state and the transient simulations. Estimates of natural recharge associated with the Amargosa Creek drainage basin were estimated by using the results from a previous application of the Basin Characteristic Model (BCM, Flint and Flint, 2007) The BCM is a distributed-parameter water-balance model that uses topography, soils, geology, and vegetation, together with monthly time-series of precipitation and air-temperature data along with other information to generate regional runoff and recharge estimates by area or basin. Results from the $\mathrm{BCM}$ indicated that mountain-front recharge, represented by the average discharge from Leona Valley as underflow, is about 1,100 acre-ft/yr and that stream recharge, represented by the average discharge from Leona Valley through Amargosa Creek, is about 200 acre-ft/yr, resulting in about $1,300 \mathrm{acre}-\mathrm{ft} / \mathrm{yr}$ of recharge to the model area. Both for steadystate and transient simulations, delays associated with flow through the unsaturated zone were assumed to be negligible and were not simulated; natural mountain-front and stream recharge were simulated by directly applying recharge water to model cells. The mountain-front recharge was applied uniformly along the area shown in figure 15, and the stream recharge was applied uniformly along the Amargosa Creek channel near the mountain front by using the well package in the form of injection wells at the node centers (see fig. 15 inset).

\section{Specified-Head Boundaries}

The entire northern boundary was a specified-head boundary assigned values on the basis of water levels in wells in the Palmdale and Lancaster area. The pre-development (pre-1924) water level was approximately 2,400 ft and was assumed to be uniform in the study area east of fault B (Leighton and Phillips, 2003). For this simulation, the hydraulic gradient across fault $\mathrm{A}$ at pre-development was assumed to be negligible, such that the water level at the northern boundary of the model was 2,400 ft at an early time. Water-level measurements in 2009 and 2010 at site 2 (just north of fault B) indicated that water levels were about 2,225 ft (figs. 8 and 15). Therefore, the specified-head boundary was defined so that head varied linearly from $2,400 \mathrm{ft}$ in 1924 to 2,225 $\mathrm{ft}$ in 2010. Although the change in water-levels might not have been linear during the entire period, this boundary condition represented a reasonable approximation of actual conditions and avoided sharp changes in boundary conditions that could have produced instabilities in the numerical simulations.

\section{Hydraulic Properties}

Aquifer properties assigned to each model cell, such as horizontal hydraulic conductivity, specific yield, and specific storage, affect the rate at which groundwater moves through an aquifer, the volume of water in storage, and the rate and areal extent of water-level rise caused by artificial recharge. Horizontal hydraulic conductivity, specific yield and specific storage were specified by using the UPW package (Niswonger and others, 2011). As stated earlier, fault B is a hydraulic barrier to groundwater flow, and the fault was simulated as a narrow region of low horizontal permeability between model cells. The horizontal hydraulic conductivity for the region north of fault B (fig. 15) was assumed to be 7 feet per day (ft/d); this value was based on the published value by Leighton and Phillips (2003) of $5 \mathrm{ft} / \mathrm{d}$ and on an aquifer test performed by RCS Consulting (written commun., 2011) indicating values ranged from about 5 to $7 \mathrm{ft} / \mathrm{d}$. The horizontal hydraulic conductivity for the region south of fault B was assumed to be $10 \mathrm{ft} / \mathrm{d}$ on the basis of Leighton and Phillips (2003) and of data collected during the drilling of monitoring sites 1 and 3 . The model was specified as unconfined; the hydraulic property quantifying storage, therefore, was the specific yield. The specific yield $(S y)$ is defined as the volume of water released from storage in an unconfined aquifer for each unit surface area of the aquifer for each unit decline in head (Lohman, 1972). The specific yield of the entire model was set to 0.14 on basis of the work of Leighton and Phillips (2003). 
During initial calibration, the local model was assumed to be horizontally homogeneous in order to determine if historic water-level data could be simulated without using horizontal-flow barriers, as if fault B did not exist. Simulations were completed by varying values of horizontal hydraulic conductivity in an attempt to match the historical water-level data. Results from these simulations showed that even with unrealistically low values of horizontal hydraulic conductivity for the entire layer 2 (below $1.5 \mathrm{ft} / \mathrm{d}$ ), the model results did not match the historic data; therefore, fault $\mathrm{B}$ was included in the simulation by assigning a low value $(0.05 \mathrm{ft} / \mathrm{d})$ for the horizontal hydraulic conductivity along the corresponding row of model cells.

\section{Model Calibration}

Hydraulic conductivity and storage values of the porous medium were obtained from previous work and were based on inspection of geologic samples collected during drilling of the monitoring sites. Only the horizontal hydraulic conductivity of fault B was estimated. The water-level data from abandoned well 6N/12W-21E1 (21E1) and from site 3 (fig. 15) were compared with corresponding simulated values. Water-level measurements collected at 21E1 showed a water-level elevation of 2,365 ft in late 1941, and subsequent measurements were dry. For calibration purposes, the dry measurements were assumed to be an indication of the water table dropping below the bottom of the well. The water-level elevation at site 3 was $2,455 \mathrm{ft}$ in early 2011, which was considered representative of conditions in 2010. These two observations were used to calibrate the model by varying the horizontal hydraulic conductivity of model cells along fault B. The hydraulic conductivity of fault B was estimated to be about $0.05 \mathrm{ft} / \mathrm{d}$.

\section{Extended Model: Artificial-Recharge Scenarios}

The purpose of the extended model was to estimate rates of recharge at the proposed recharge facility by using test scenarios and to determine how estimated rates of recharge affect the water table in the study area. To accomplish this, the domain of the model was extended to minimize the effects of boundary conditions on model results. The model domain was extended about $6.5 \mathrm{mi}$ northeastward, such that the northwest corner of the extended model was north of the city of Lancaster (fig. 18). Artificial-recharge scenarios were designed to estimate the maximum 20-year recharge rates on the basis of a range of horizontal conductivity values determined from lithologic information obtained during drilling of the monitoring wells and from previously reported values. To address concerns for liquefaction, a liquefaction constraint based on the work of Martin and Lew (1999) was defined such that water levels cannot rise within $50 \mathrm{ft}$ of land surface in the model domain, except beneath the proposed artificial-recharge facility.

\section{Spatial Discretization}

The extended model consisted of a 203-row by $264-c o l u m n$ grid with $200-\mathrm{ft}$ by $200-\mathrm{ft}$ cells. Two model layers were specified in order to simulate artificial-recharge scenarios in which the water table rises into the coarse-grained, more permeable gravels and coarse sand associated with young fan deposits (Qyf; figs. 16 and 17).

Layer 1 comprises the fan deposits, with a thickness assumed to be about $150 \mathrm{ft}$ in the model domain; therefore, the bottom elevation of model layer 1 was defined as land surface minus $150 \mathrm{ft}$. Land-surface elevation for the top of model layer 1 in the extended model was extracted from $10-\mathrm{m}$ National Elevation Dataset 2009 data at model cell centers (Gesch, 2007). Land-surface elevations for the extended model range from about 2,840 ft along the foothills west of Palmdale and along Amargosa Creek to about 2,320 ft at the northwest corner of the model near Lancaster. The bottom elevation of layer 1 varies from 2,690 to 2,170 ft.

Model layer 2 represents the lower part of the upper aquifer and the middle aquifer, consisting of older, less permeable material composed of old and very old alluvial deposits (Qoa and Qvoa); it extends from the bottom of layer 1 to the bottom of the model domain (fig. 15 and 16). The bottom of the model domain was assumed to be either the bedrock complex or the extremely low-permeability blue clay of the lacustrine deposits (Qvol), whichever is shallowest (fig. 15 and 16). Because of the extremely low permeability of these units, they were not simulated (Leighton and Phillips, 2003). The thickness of layer 2 ranges from about 10 to $150 \mathrm{ft}$ along the mountain front to about $1,000 \mathrm{ft}$ near the center of the model domain.

\section{Temporal Discretization}

Artificial-recharge scenarios were simulated by using a combined steady-state and transient simulation. The steadystate simulation represented conditions in 2011, prior to the application of SWP recharge water. This approach assumed that the system was in a state of equilibrium in 2011. This is not completely valid because the Antelope Valley groundwater basin was in a state of overdraft by 2003 (Leighton and Phillips, 2003). The effects of regional water-level declines on groundwater levels local to the ACRP have been gradual and have diminished during recent years; therefore, the local system near the ACRP was assumed to be in an approximate state of equilibrium. For the purposes of this study, the primary objective of which was to estimate the system response to artificial-recharge operations at the ACRP, the consequences of the steady-state assumption were minimal; relative changes in water levels were more important than their absolute magnitudes. Water levels change during the transient simulation only if artificial recharge is applied, which was consistent with the objective of this study. 
The hydraulic-head distribution of the steady-state simulation was used as the initial condition for the transient simulation. The transient simulation began in January 2012 and ended in December 2031, totaling 520 biweekly stress periods.

\section{Model Boundaries}

The extended groundwater-flow model contains two types of boundary conditions: specified flux and specified head. Three specified-flux boundaries represent natural recharge, artificial recharge, and no-flow, or zero-flux (fig. 15). Specified-head boundaries were based on the 2011 water levels measured in wells along the northeastern boundary.

\section{Specified-Flux Boundaries}

Natural mountain-front recharge and natural stream recharge were the same as in the local model, about 1,100 acre-ft/yr and $200 \mathrm{acre}-\mathrm{ft} / \mathrm{yr}$, respectively. For all simulations, delays associated with flow through the unsaturated zone were assumed to be negligible; mountainfront and artificial recharge were applied directly to the water table. Artificial recharge was applied to the upper most active layer and was assumed to be constant during the 20-year simulation. The artificial-recharge cells were located at the proposed recharge facility (fig. 15 inset). A model cell was considered an artificial-recharge cell if at least half of the cell was contained within the proposed recharge facility boundary. Recharge was applied uniformly over these cells.

\section{Specified-Head Boundaries}

The northeastern boundary for the extended model was a specified-head boundary condition (fig 18). The head specified at this boundary was constant at 2,150 ft, which was based on average water-level observations in 2009 at wells along the boundary (fig. 8). This temporally constant specified-head assumption did not consider the downward trend in water-levels in the regional basin that started the early $1900 \mathrm{~s}$ (Leighton and Phillips, 2003). If this trend continues, it could increase the hydraulic gradient and associated groundwater flow across the faults, resulting in an increase in the maximum volume of potential artificial recharge at the ACRP site.

\section{Simulated Faults}

The extended model domain included fault A (figs. 14, 15, and 16), described by Bloyd (1967). Similar to fault B, fault A was simulated by lowering the horizontal hydraulic conductivity of a row of model cells at the appropriate locations (fig. 17 and 18). The hydraulic conductivity of fault A required an additional calibration phase for the extended -domain steady-state model representing 2011 conditions. The hydraulic conductivity of fault B was the same as the calibrated values derived from the local model.

\section{Hydraulic Properties}

The same aquifer properties used in the steady-state local model were initially assigned to each model cell in the steadystate extended model. Both model layers were assumed to be convertible; that is, they can be either confined or unconfined depending on the elevation of the water table. Faults A and B were considered potential hydraulic barriers to groundwater flow; these faults were simulated as narrow regions of low conductivity. The horizontal hydraulic conductivity for layer 2 in the portion of the model north of fault $\mathrm{A}$ was assumed to be homogeneous at $7 \mathrm{ft} / \mathrm{d}$. The horizontal hydraulic conductivity of layer 2 in the region south of fault A remained $10 \mathrm{ft} / \mathrm{d}$. The vertical hydraulic conductivity for all simulations was $1 \mathrm{ft} / \mathrm{d}$.

The specific yield of layers 1 and 2 for the entire model remained 0.14 , and the specific storage remained $10^{-6} \mathrm{ft}^{-1}$. At the initial condition, layer 1 was completely dry, and therefore, layer 2 was completely unconfined. Model cells in layer 2 only become confined in areas where the water level rises high enough to wet layer 1 . Furthermore, layer 1 is always unconfined because of the liquefaction constraint of $50 \mathrm{ft}$ below the top of the cell. Therefore, the specific storage of layer 1 is never used, and the specific storage of layer 2 is only used for a small portion of the model near the ACRP. As a result, the model is not sensitive to values of specific storage.

\section{Model Calibration}

The properties of model layer 1 cannot be calibrated because the entire model layer was dry at steady state. Therefore, the extended model contained only one additional parameter to be estimated - the hydraulic conductivity of fault A. The observation data consisted of the measured water level altitude at site 2 (about 2,225 ft in 2010) and the measured water level altitude at site 3 (about 2,455 ft in 2011). This calibration was performed manually using the steady-state (2011) simulation; the resulting hydraulic head distribution was used as the initial head distribution for transient-statemodel simulations of artificial-recharge potential at the ACRP site. The calibrated hydraulic conductivity of fault A was $1.4 \mathrm{ft} / \mathrm{d}$

\section{Model Results}

The transient version of the extended model was used to determine how a range of possible horizontal conductivity values would affect the long-term volume of applied artificial recharge at the proposed recharge facility. The amount of water that can be recharged at the proposed artificial-recharge facility depends greatly on the horizontal hydraulic conductivity of layer 1 , which represents the porous medium within $150 \mathrm{ft}$ of the land surface. For this study, two layer-1 horizontal hydraulic conductivity values were tested: 10 (scenario 1) and $100 \mathrm{ft} / \mathrm{d}$ (scenario 2). The value of $10 \mathrm{ft} / \mathrm{d}$ was based on the work of Leighton and Phillips (2003) from deeper materials in (Qoa) layer 1. Previous 


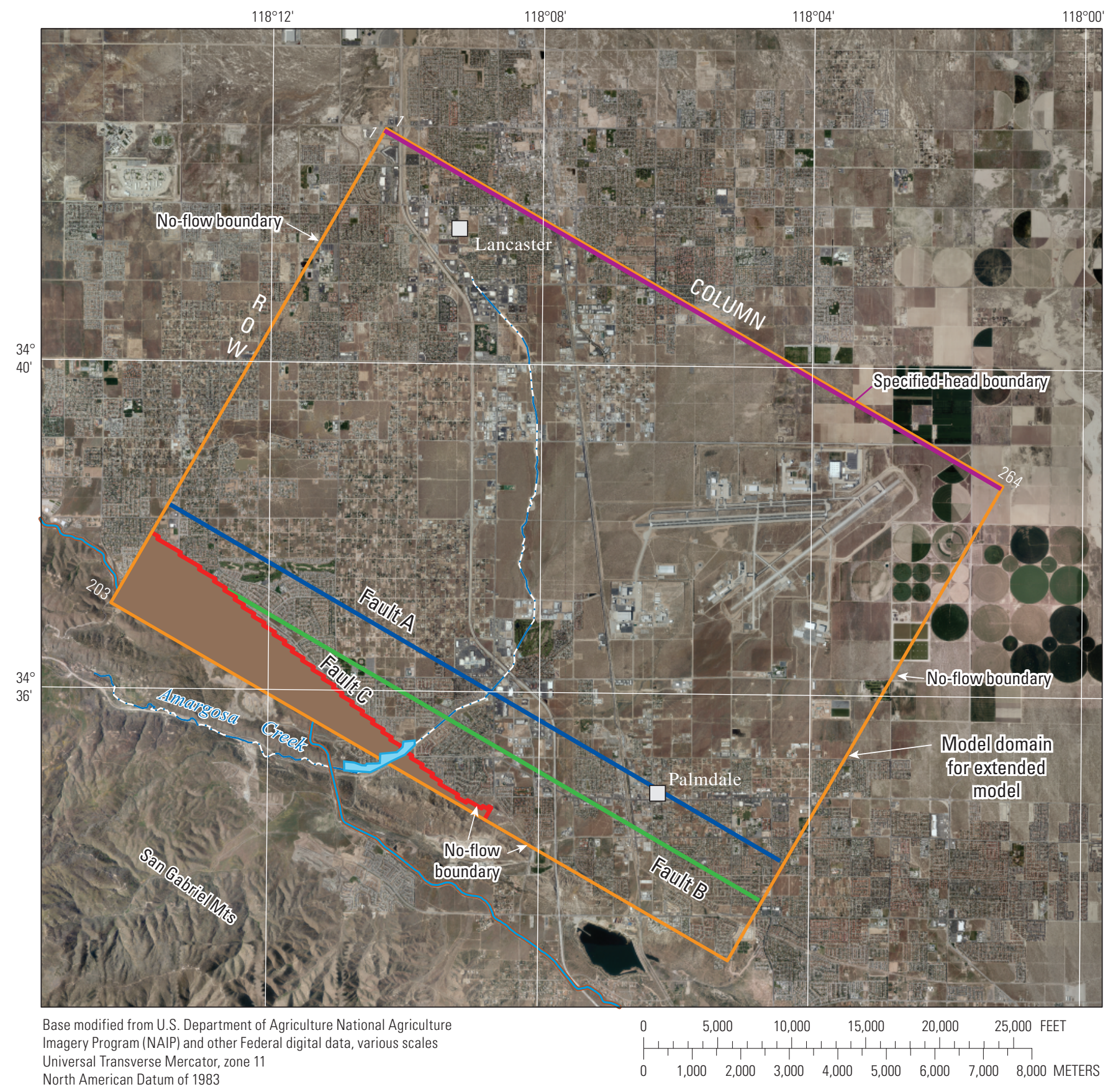

EXPLANATION
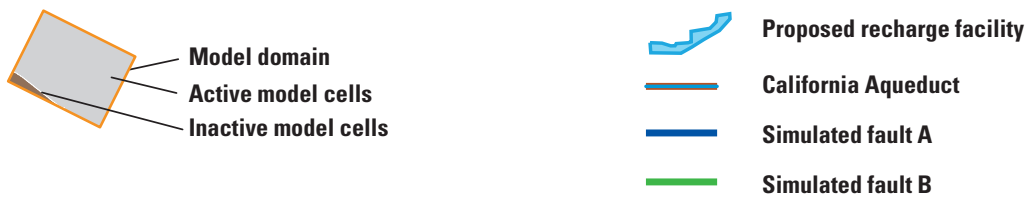

Figure 18. Extended model domain, model boundary location, type of boundary and location of Amargosa Creek Recharge Project, Antelope Valley, California. 
work of Leighton and Phillips did not simulate the young alluvial fan deposits because they were unsaturated because of dewatering early in the simulation period. The value of $100 \mathrm{ft} / \mathrm{d}$ was based on the analysis of drill cuttings collected during drilling of the monitoring sites. As stated previously, the materials encountered in the upper $150 \mathrm{ft}$ in the vicinity of the recharge facility were mainly clean sands and coarse gravels interbedded with silty sands; a horizontal conductivity value of $100 \mathrm{ft} / \mathrm{d}$ was consistent with these coarse-textured materials (Freeze and Cherry, 1979). In general, simulation results from scenario 1 indicated that the lower value of horizontal hydraulic conductivity in layer 1 slowed the lateral spread of recharge water, causing groundwater mounding near the ACRP. At a horizontal conductivity of $10 \mathrm{ft} / \mathrm{d}$, simulated artificial-recharge rates exceeding 3,400 acre-ft/yr caused water levels surrounding the ACRP to rise within $50 \mathrm{ft}$ of land surface (which was the selected liquefaction constraint). Artificial recharge at the ACRP must then be halted or reduced to prevent further water-level rise. In general, simulation results from scenario 2 indicated that the greater horizontal hydraulic conductivity $(100 \mathrm{ft} / \mathrm{d})$ in layer 1 would allow greater lateral spreading of artificial-recharge water, reducing the mounding effect. As a result, artificial recharge of up to 9,400 acre-ft/yr could be applied before the liquefaction constraint is reached in the scenario 2 simulation.

Assuming hydraulic conductivities for model-layer 1 of 10 and $100 \mathrm{ft} / \mathrm{d}$, the maximum artificial-recharge rates were approximately 3,400 and 9,400 acre-ft/yr for the scenario 1 and 220 -year simulations, respectively. Figures 19 and 20 show the distribution of increases in hydraulic head at the end of the 20-year simulations for values of 10 and $100 \mathrm{ft} / \mathrm{d}$ for layer-1 hydraulic conductivity, respectively. As expected, greater recharge rates and hydraulic conductivities caused an increase in head further into the valley. The simulated-head increases for scenario 1 extended radially about $4 \mathrm{mi}$ from the ACRP toward western Palmdale and southern Lancaster (fig. 19); for scenario 2, the head increase extended about $6 \mathrm{mi}$ (fig. 20).

Using a hydraulic conductivity value of $10 \mathrm{ft} / \mathrm{d}$ resulted in the greatest rise in simulated hydraulic head beneath the recharge facility. The rise resulted from the low hydraulic conductivity preventing the water from spreading laterally from recharge facility to a greater degree during the $20-\mathrm{yr}$ simulation period (fig. 19). Using a hydraulic conductivity value of $100 \mathrm{ft} / \mathrm{d}$ resulted in the greatest rise in simulated hydraulic head in the cells just north of fault B along Amargosa Creek (fig. 20). This rise resulted from increased recharge and lateral flow in layer 1, which mounded first at the south side of fault B. This mounding increased the hydraulic gradient across the fault, resulting in greater flow across the fault and in increased water levels on both sides of the fault. Additionally, at the end of scenario 2, the model cells in layer 1 directly above fault $\mathrm{B}$ became active, or wet, indicating that flow could eventually go over the top of the fault through the more permeable materials of layer 1 . The area affected by recharge down-gradient from the ACRP in scenario 2 was also approximately 50 percent larger than that in scenario 1 . Based on a 20 -year simulation period and hydraulic conductivities of 10 and $100 \mathrm{ft} / \mathrm{d}$, the estimated maximum total artificialrecharge volume to the Antelope Valley groundwater basin using the ACRP was between 68,000 and 188,000 acre-ft $(3,400-9,400$ acre-ft/yr).

\section{Limitations and Appropriate Use of the Models}

The groundwater-flow models were developed to understand the groundwater-flow system better in the vicinity of the ACRP and to estimate potential recharge rates. Limitations of the modeling software, assumptions made during model development, and the focus and robustness of model calibration are factors that constrain the appropriate use of these models and point to potential improvements.

A numerical groundwater-flow model is a simplified representation of the actual groundwater-flow system. The models are based on simplifying assumptions and approximations, and, therefore, they do not exactly represent the inherent complexity of the geohydrologic framework. The results of model simulation are only an approximation or estimation of actual conditions and are only as accurate or realistic as the assumptions and data used in its development.

Assumptions used to develop the models in this study included the following:

- Both models assumed that historical groundwater pumping did not cause aquifer deformation or compaction.

- Both models assumed active tectonism did not affect the groundwater-flow system during the model simulations.

- Both models assumed the older sedimentary deposits and crystalline basement rocks that underlie the study area did not contribute groundwater to the flow system.

- In the extended model, simulated water levels were not allowed to rise to within $50 \mathrm{ft}$ of land surface to avoid potential liquefaction.

A steady-state model portrays a system that is in equilibrium. The work of Leighton and Phillips (2003) showed a general downward trend in the hydraulic head since the early 1900s. Long-term hydrographs were not available for some areas in the study area, including the southeastern part of the model area near Palmdale, where hydraulic heads could have changed over time. There were no long-term water-level records available for the local model area; water levels in the closest wells (within $5 \mathrm{mi}$ ) showed little change since the mid-1980s. Although many water-level hydrographs showed a general decline in the study area over time, the objective of the study was to determine the potential relative effects of artificial recharge at the ACRP. Errors related to the assumption of a steady-state condition could be important in places; however, this approach results in reasonable estimates of potential artificial-recharge rates. 


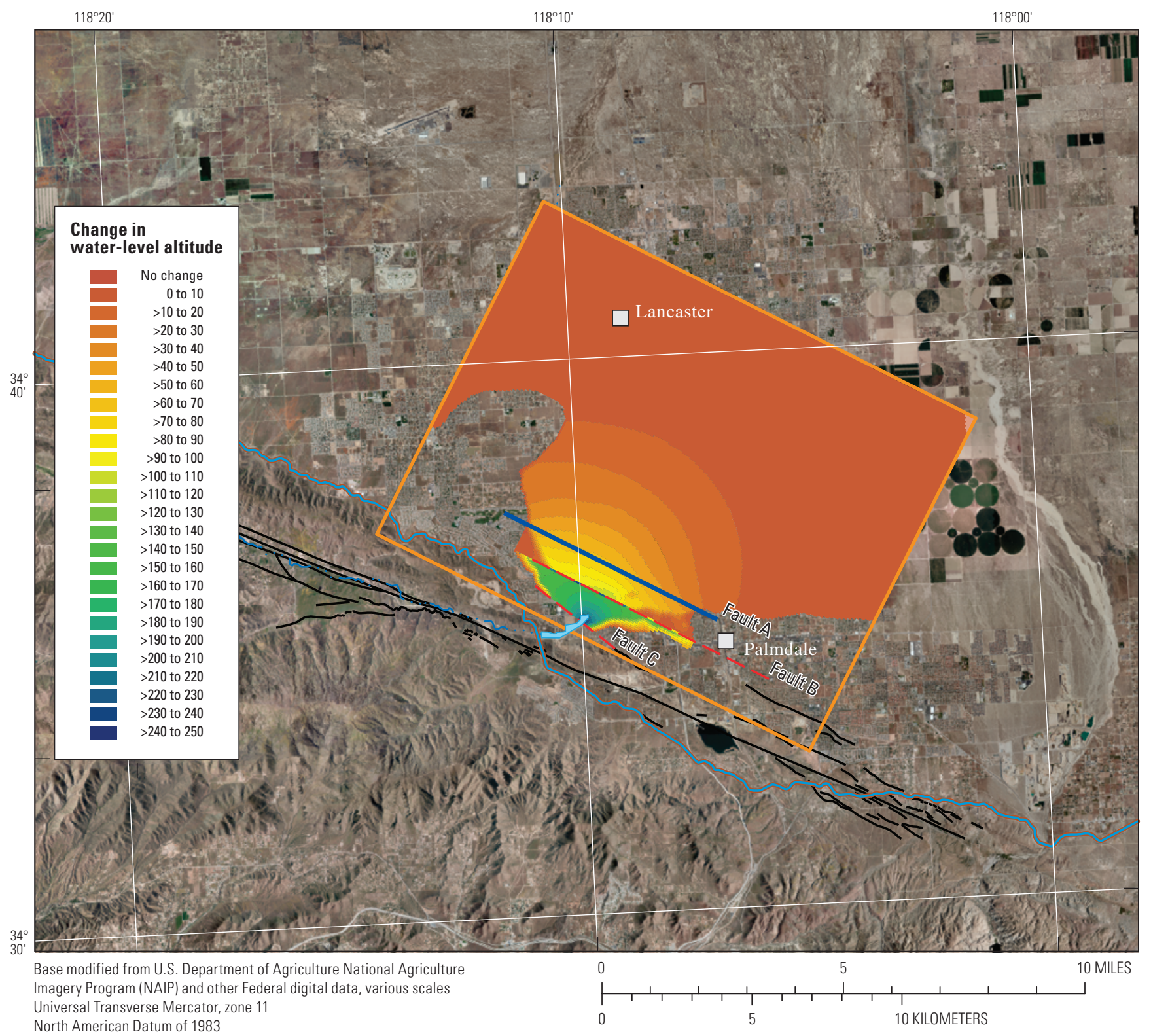

North American Datum of 1983

\section{EXPLANATION}

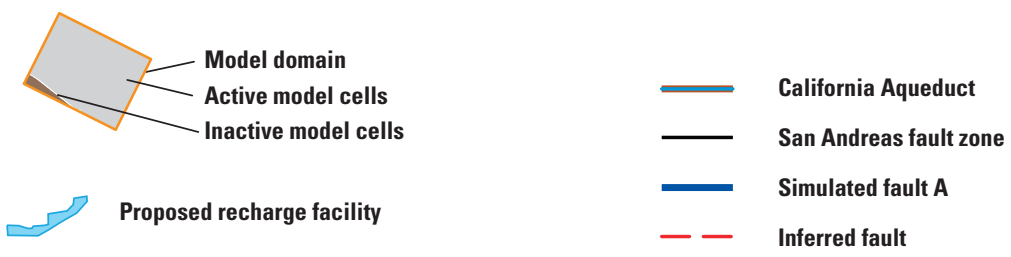

Figure 19. Scenario 1, change in head after 20-year artificial-recharge simulation, assuming that layer 1 hydraulic conductivity was equal to 10 feet per day and an artificial-recharge rate of 3,400 acre-feet per year, Antelope Valley, California. 


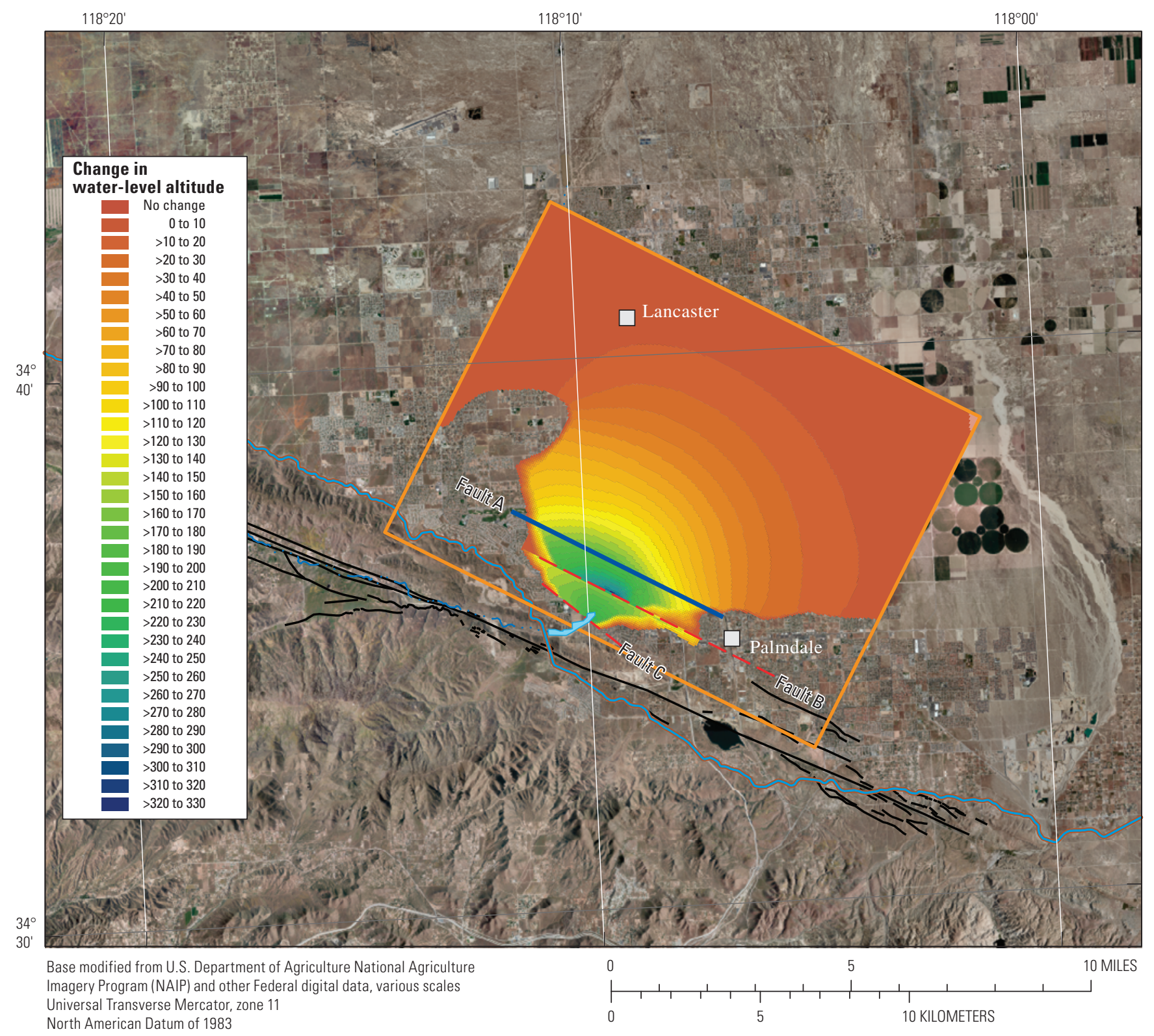

EXPLANATION
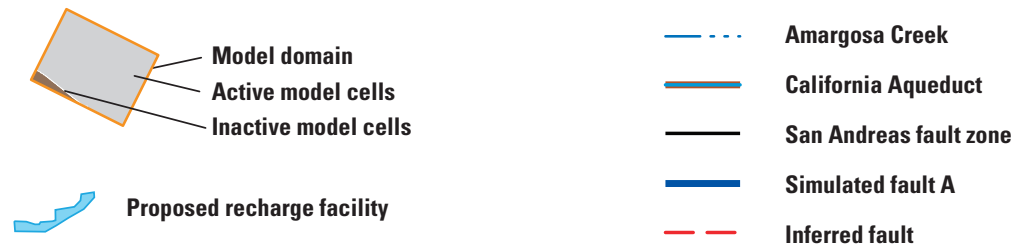

Figure 20. Scenario 2, change in head after 20-year artificial-recharge simulation, assuming that layer 1 hydraulic conductivity was equal to 100 feet per day and an artificial-recharge rate of 9,400 acre-feet per year, Antelope Valley, California. 


\section{Feasibility and Potential Effects of the Proposed Amargosa Creek Recharge Project}

Future improvements to the extended model could result from (1) completion of additional wells or borings to document the lateral extent of the coarse materials in the upper $150 \mathrm{ft}$; (2) additional wells completed to the water table between Faults A, B, and C to help determine gradients between or across faults; (3) unsaturated-zone monitoring sites near the proposed recharge facility to monitor or to document flow through, and storage in, the unsaturated zone; and (4) a pilot recharge test or documented natural recharge event coupled with monitoring to document the response to recharge in the vicinity of the proposed recharge facility. Results from all or some of these possible actions can be used to improve and recalibrate the extended model, which can, in turn, improve the quality of results from model simulations or from management decisions derived from model simulations.

\section{Summary and Conclusions}

Historically, the city of Palmdale and vicinity have relied on groundwater as the primary source of water, owing, in large part, to the scarcity of surface water in the region. Since 1972, supplemental surface water has been imported from the State Water Project (SWP) to help meet the demand for water. Despite the importation of surface water, groundwater withdrawal for municipal, industrial, and agricultural use has resulted in ground-water-level declines near the city of Palmdale in excess of 200 feet (ft) since the early 1900s. To help meet the growing demand for water in the area, the city of Palmdale has proposed the Amargosa Creek Recharge Project (ACRP). Water delivered by the SWP through the California Aqueduct will be used to fill percolation basins at the site. The city of Palmdale is concerned about the effects of artificial recharge on groundwater levels near the recharge facility and, because of the proximity of the recharge facility to the San Andreas fault zone, the potential presence of faults that could act as groundwater barriers and impede the downgradient movement of recharge to the aquifer system underlying the Palmdale area.

Several methods were used to help describe the basement geometry and thickness of valley-fill deposits and to identify possible features, such as faults, that could influence groundwater flow. These methods included regional gravity surveys, seismic refraction and reflection surveys, resistivity surveys, test borings completed with monitoring wells, data collected from the monitoring wells, and the development of a numerical groundwater-flow model to simulate the groundwater-flow system and the potential effects of artificial recharge.

The regional gravity data provided details of the subsurface topology in the study area and showed an alluvialfilled trough trending northeast from the ACRP, a buried basement ridge that trends north toward Lancaster, and a buried plateau extending southeast of the ACRP toward Palmdale. Shallow-depth seismic refraction and reflection surveys and resistivity surveys along the Amargosa Creek identified major disruptions in the basement that were interpreted as faults, but were not evident in the regional gravity data. Differences in water levels across the faults indicated they are partial barriers to groundwater flow.

In general, water samples collected from sites 1,2 , and 3 indicated that the groundwater near the ACRP is of good quality. Concentrations of common groundwater constituents of concern, including nitrate plus nitrite, fluoride, and arsenic, were below U.S. Environmental Protection Agency maximum contaminant levels in samples collected from sites 1, 2, and 3. Selected volatile organic compound concentrations were all below detection limits for samples collected from sites 1 and 2. Stable-isotope data indicated that the source of water for wells at sites 1 and 3 was consistent with water found in Leona Valley, upstream in the Amargosa Creek watershed. This was consistent with carbon and tritium values that indicated water recharged since the 1950s at site 1, and a mixture of water recharged since the $1950 \mathrm{~s}$ with older water at site 3 . Stable isotope, ${ }^{14} \mathrm{C}$ values, and trace detection of tritium in water collected at site 2, downstream of the ACRP along the Amargosa Creek and on the northeast side of fault B, indicated that groundwater at this site is similar to groundwater collected from the Antelope Valley groundwater basin and that modern-day recharge is not a major source for this well.

A local groundwater-flow model was used to estimate the hydraulic conductivity of fault B in the model domain. The extended groundwater-flow model was developed to simulate the groundwater-flow system and the potential effects of artificial recharge of imported water at the ACRP. The amount of water that can be recharged at the proposed artificial-recharge facility depended largely on the hydraulic conductivity of the coarse material closer to the land surface (upper $150 \mathrm{ft}$ for the extended-model layer 1). The range for hydraulic conductivity of layer 1 was estimated to be between 10 and 100 feet per day (ft/d) on the basis of previous work and data collected as part of this study. A liquefaction constraint was set so that water levels cannot rise within $50 \mathrm{ft}$ of land surface in the model domain, except for the area directly beneath the proposed artificial-recharge facility. Assuming hydraulic-conductivity values of 10 (scenario 1) and $100 \mathrm{ft} / \mathrm{d}$ (scenario 2), the calculated maximum artificial-recharge rates were 3,400 and 9,400 acre-feet per year (acre-ft/yr), respectively. Scenario 2 results showed elevated heads in an area 50 percent larger than the scenario 1 results. Based on a 20-year simulation period and hydraulic conductivities of 10 and $100 \mathrm{ft} / \mathrm{d}$, the estimated maximum total artificial-recharge volume to the Antelope Valley groundwater basin using the ACRP was between 68,000 and 188,000 acre-ft $(3,400-9,400$ acre-ft/yr). 


\section{References Cited}

Binley, A., and Kemna, A., 2005, DC resistivity and induced polarization methods, in Rubin, Y., and Hubbard, S.S., eds., Hydrogeophysics: Netherlands, Springer, p. 129-156.

Bloyd, R.M., Jr., 1967, Water resources of the Antelope Valley-East Kern Water Agency area, California: U.S. Geological Survey Open-File Report 67-20, 73 p.

Brenton, R.W., and Arnett, T.L., 1993, Methods of analysis by the U.S. Geological Survey National Water Quality Laboratory-Determination of dissolved organic carbon by uv-promoted persulfate oxidation and infrared spectrometry: U.S. Geological Survey Open-File Report 92-480, 12 p. Method ID: O-1122-92.

Brouwer, J., and Helbig, K., 1998, Shallow high-resolution reflection seismics, in: Helbig, K. and Treitel, S., eds., Handbook of geophysical exploration, 19: Oxford, Elsevier, $391 \mathrm{p}$.

California Geological Survey CD-ROM 2001-05, 2002, Official map of Alquist-Priolo earthquake fault zones, Ritter Ridge quadrangle 1:24,000.

Catchings, R.D., Rymer, M.J. Goldman, M.R., and Gandhok, G., 2009, San Andreas fault geometry at Desert Hot Springs, California, and its effects on earthquake hazards and groundwater: Bulletin of the Seismological Socciety of America, v. 99, p. 2190-2207.

Christensen, A.H., 1999, Generalized water-table and waterlevel data at the US Air Force plant 42 and vicinity, Palmdale, California, March-April, 1997: Water Resources Investigations Report 99-4262, p.

Christensen, A.H., 2005, Generalized water-level contours, September-October 2000 and March-April 2001, and longterm water-level changes, at the U.S. Air Force Plant 42 and vicinity, Palmdale, California: U.S. Geological Survey Scientific Investigations Report 2005-5074, 131p.

Clark, I.D., and Fritz, P., 1997, Environmental Isotopes in Hydrogeology: Boca Raton, Fla., CRC Press, 328 p.

Connor, B.F., Rose, D.L., Noriega, M.C., Murtagh, L.K., and Abney, S.R., 1998, Methods of analysis by the U.S. Geological Survey National Water Quality Laboratory-Determination of 86 volatile organic compounds in water by gas chromatography/mass spectrometry, including detections less than reporting limits: U.S. Geological Survey OpenFile Report 97-829, 78 p., Method ID: O-4127-96

Craig, Harmon, 1961, Isotope variations in meteoric water: Science, v. 133, p. 1702-1703.
Dibblee, T.W., 1960, Geologic map of the Lancaster quadrangle, Los Angeles county, California: U.S. Geological Survey Mineral Investigations Field Map MF-76, scale 1:62,500.

Dibblee, T.W., 1963, Geology of the Willow Springs and Rosamond quadrangles, California: U.S. Geological Survey Bulletin 1089-C, p. 141-253.

Dibblee, T.W., 1967, Areal geology of the western Mojave Desert, California: U.S. Geological Survey Professional Paper 522, $153 \mathrm{p}$.

Dobrin, M.B., and Savit, C.H., 1988, Introduction to geophysical prospecting: San Francisco, Calif., McGraw-Hill Book Co., 867 p.

Durbin, T.J., 1978, Calibration of a mathematical model of the Antelope Valley groundwater basin, California: U.S. Geological Survey Water-Supply Paper 2046, 51 p.

Dutcher, L.C., and Worts, G.F., Jr., 1963, Geology, hydrology and water supply of Edwards Air Force Base, Kern County, California: U.S. Geological Survey Open-File Report, $225 \mathrm{p}$.

Evans, J.G., 1978, Postcrystalline deformation of the Pelona Schist bordering Leona Valley, southern California: U.S. Geological Survey Professional Paper 1039, scale 1:10000.

Fishman, M.J., ed., 1993, Methods of analysis by the U.S. Geological Survey National Water Quality LaboratoryDetermination of inorganic and organic constituents in water and fluvial sediments: U.S. Geological Survey OpenFile Report 93-125, 217 p. Method ID: I-1472-87.

Fishman, M.J., and Friedman, L.C., 1989, Methods for determination of inorganic substances in water and fluvial sediments: U.S. Geological Survey Techniques of WaterResources Investigations, book 5, chap. A1, 545 p. Method ID: I-2781-85, I-2587-89, I-2327-85, I-2057-85, I-237185 , I-2700-85, I-1750-89, I-2030-89.

Flint, L.E., and Flint, A.L. in Stonestrom, D.A., Constantz, J., Ferré, T.P.A., and Leake, S.A., eds., 2007, Groundwater Recharge in the Arid and Semiarid Southwestern United States: U.S. Geological Survey Professional Paper 1703, Reston, Va. 426 p., http://pubs.usgs.gov/pp/pp1703/.

Freeze, R.A., and Cherry, J.A., 1979, Groundwater: Englewood Cliffs, N.J., Prentice-Hall, Inc., 604 p.

Garbarino, J.R., Kanagy, L.K., and Cree, M.E., 2006, Determination of elements in natural-water, biota, sediment and soil samples using collision/reaction cell inductively coupled plasma-mass spectrometry: U.S. Geological Survey Techniques and Methods, book 5, sec. B, chap. 1, 88 p. Method ID: I-2020-05. 
Gesch, D.B., 2007, The National Elevation Dataset, in Maune, D., ed., Digital Elevation Model technologies and applications: The DEM user's manual, 2nd edition: Bethesda, Md., American Society for Photogrammetry and Remote Sensing, p. 99-118.

Gonfiantini, Roberto, 1978, Standards for stable isotope measurements in natural compounds: Nature, v. 271, p. $534-536$.

Harbaugh, A.W., 2005, MODFLOW-2005, U.S. Geological Survey modular groundwater model - the groundwater flow process: U.S. Geological Survey modeling techniques, book 6, section A, chap. 16, 253 p.

Hernandez, J.L., 2009, Geologic map of the Ritter Ridge 7.5-minute' quadrangle, Los Angeles County, California: A digital database: California Geological Survey, Preliminary Geologic Maps, scale 1:24000.

Hernandez, J.L., 2010a, Geologic map of the Del Sur 7.5-minute quadrangle, Los Angeles County, California: A digital database: California Geological Survey, Preliminary Geologic Maps, scale 1:24000.

Hernandez, J.L., 2010b, Geologic map of the Lancaster West 7.5-minute quadrangle, Los Angeles County, California: A digital database: California Geological Survey, Preliminary Geologic Maps, scale 1:24000.

Hewett, D.F., 1954, General geology of the Mojave Desert region California, in Jahns, R.H. Baily, T.L., eds., Geology of southern California: Department of Mines and Geology Bulletin 170, chap. 2, p. 2-20.

Hole, J.A, 1992, Nonlinear high-resolution three-dimensional seismic travel time tomography: Journal of Geophysical Research, v. 97, p. 6553-6562.

International Union of Geodesy and Geophysics, 1971, Geodetic Reference System 1967: International Association of Geodesy Special Publication no. 3, 116 p.

Izbicki, J.A., Martin, Peter, and Michel, R.L., 1995, Source, movement, and age of groundwater in the upper part of the Mojave River Basin, California, U.S.A., in Adar, E.M., and Leibundgut, Christian, eds., Application of tracers in arid zone hydrology: International Association of Hydrological Sciences, no. 232, p. 43-56.

Jachens, R.C., and Moring, B.C., 1990, Maps of the thickness of Cenozoic deposits and the isostatic residual gravity over basement for Nevada: U.S. Geological Survey Open-File Report 90-404, 15 p., 2 pls.

Johnson, H.R., 1911, Water resources of Antelope Valley, California: U.S. Geological Survey Water-Supply Paper 278, 92 p.
Kalin, R.M., 2000, Radiocarbon dating of groundwater systems, in Cook, P.G., and Herczeg, A.L., eds., Chapter 4: Environmental tracers in subsurface hydrology: Boston, Mass., Kluwer Academic Publishers, p. 111-144.

Karki, P., Kivioja, L., and Heiskanen, W.A., 1961, Topographic isostatic reduction maps for the world for the Hayford zones 18-1, Airy-Heiskanen System, T=30 km: Isostatic Institute of the International Association of Geodesy, no. 35, 5 p., 20 pl.

Karlen, I., Olsson, I.U., Kallburg, P., and Kilici, S., 1964, Absolute determination of the activity of two ${ }^{14} \mathrm{C}$ dating standards: Arkiv Geofysik, v., p. 465-471.

Langenheim, V.E., Jachens, R.C., Matti, J.C., Hauksson, Egill, Morton, D.M., and Christensen, A., 2005, Geophysical evidence for wedging in the San Gorgonio Pass structural knot, southern San Andreas fault zone, southern California: Geological Society of America Bulletin, v. 117, no. 11, p. 1554-1572.

Leighton, D.A., Phillips, S.P., 2003, Simulation of groundwater flow and land subsidence in the Antelope Valley groundwater basin, California: Water Resources Investigations Report, 2003-4016, 118 p.

Lohman, S.W., 1972, Groundwater hydraulics: U.S. Geological Survey Professional Paper 708, 70 p.

Loke, M.H., and Barker, R.D., 1996, Rapid least-squares inversion of apparent resistivity pseudosections by a quasiNewton method: Geophysical Prospecting, v. 44, no. 1, p. 131-152.

Londquist, C.J., and Martin, Peter, 1991, Geohydrology and ground-water-flow simulation of the Surprise Spring basin aquifer system, San Bernardino County, California: U.S. Geological Survey Water-Resources Investigations Report 89-4099, 41 p.

Londquist, C.J., Rewis, D.L., Galloway, D.L., and McCaffrey, W.F., 1993, Hydrogeology and land subsidence, Edwards Air Force Base, Antelope Valley, California, January 1989December 1991: U.S. Geological Survey Water-Resources Investigations Report 93-4114, 74 p.

Los Angeles County Department of Public Works, 1991, Antelope Valley groundwater recharge study, phase two, Air Force site along Amargosa Creek, 109 p., http://www.ladpw. org/wwd/avirwmp/docs/Antelope\%20Valley\%20Groundwater\%20Recharge\%20Study,\%20Phase\%202.pdf.

Mabey, D.R., 1960, Gravity survey of the western Mojave Desert, California: U.S. Geological Survey Professional Paper 316-D, p. 51-73. 
Martin, G.R., and Lew, M., eds., 1999, Recommended procedures for implementation of DMG special publication 117 Guidelines for analyzing and mitigating liquefaction hazards in California: Southern California Earthquake Center, p. 63.

Michel, R.L, 1976, Tritium inventories of the world oceans and their implications: Nature, v. 263, p. 103-106.

Minsley, B.J., Ball, L.B., Burton, B.L., Caine, J.S., CurryElrod, E., and Manning, A.H., 2009, Geophysical characterization of subsurface properties relevant to the hydrology of the Standard Mine in Elk Creek Basin, Colorado: U.S. Geological Survey Open-File Report 2009-1284, 46 p.

Mook, W.G., 1980, The dissolution-exchange model for dating of groundwater with ${ }^{14} \mathrm{C}$, in Fritz, P., and Fontes, J.C., eds., Handbook of Environmental Isotopes Geochemistry, v. 1: Amsterdam, Netherlands, Elsevier, p. 50-74.

Morelli, C., ed., 1974, The International Gravity Standardization Net, 1971: International Association of Geodesy Special Publication no. 4, 194 p.

Morton, R.A., Leach, M.P., Paine, J.G., Cardoza, M.A., 1993, Monitoring beach changes using GPS surveying techniques: Journal of Coastal Research, v. 9, no. 3, 702-720.

Nishikawa, Tracy, Rewis, D.L., and Martin, Peter, 2001, Numerical model of ground-water flow and land subsidence for Edwards Air Force Base, Antelope Valley, California: U.S. Geological Survey Water-Resources Investigations Report 01-4038.

Niswonger, R.G., Panday, S., and Ibaraki, M., 2011, MODFLOW-NWT, A Newton Formulation for MODFLOW-2005: U.S. Geological Survey Techniques and Methods 6-A37.

Norris, M.W., and Faichney, A.K., eds., 2001, SEG Y rev 1 data exchange format: Society of Exploration Geophysicist, p. 45.

Oldenburg, D.W., and Li, Y., 1994, Inversion of induced polarization data: Geophysics, v. 59, no. 9, p. 1327-1341.

Olson, B.P.E, and Hernandez, J.L., 2013, Preliminary geologic map of the Palmdale 7.5-minute quadrangle, Los Angeles County, California: A digital database: California Geological Survey, Preliminary Geologic Maps, scale 1:24000.

Olsson, I.U., 1970, The use of oxalic acid as a standard, in Olsson, I.U., ed., Radiocarbon Variations and Absolute Chronology, Nobel Symposium, 12th Proc.: New York, N.Y., John Wiley \& Sons, p. 17.
Ostlund, H.G., and Werner, E., 1962, The electrolytic enrichment of tritium and deuterium for natural tritium measurements, in Tritium in the Physical and Biological Sciences, v. 1: Vienna, Austria, International Atomic Energy Agency, p. 95-104.

Patton, C.J., and Kryskalla, J.R., 2011, Colorimetric determination of nitrate plus nitrite in water by enzymatic reduction, automated discrete analyzer methods: U.S. Geological Survey Techniques and Methods, book 5, chap. B8, Method ID: I-2547-11.

Patton, C.J., and Truitt, E.P., 1992, Methods of analysis by the U.S. Geological Survey National Water Quality Laboratory-Determination of total phosphorus by a Kjeldahl digestion method and an automated colorimetric finish that includes dialysis: U.S. Geological Survey Open-File Report 92-146, 39 p., Method ID: I-2610-91.

Patton, C.J., and Truitt, E.P., 2000, Methods of analysis by the U.S. Geological Survey National Water Quality Laboratory-Determination of ammonium plus organic nitrogen by a Kjeldahl digestion method and an automated photometric finish that includes digest cleanup by gas diffusion: U.S. Geological Survey Open-File Report 00-170, 31 p., Method ID: I-2515-91.

Plouff, D., 1977, Preliminary documentation for a FORTRAN program to compute gravity terrain corrections based on topography digitized on a geographic grid: U.S. Geological Survey Open-File Report 77-535, 45 p.

Révész, Kinga, and Coplen, T.B., 2008a, Determination of the $\delta(2 \mathrm{H} / 1 \mathrm{H})$ of water: RSIL lab code 1574 , chap. C1 of Révész, Kinga, and Coplen, T.B., eds., Methods of the Reston Stable Isotope Laboratory: U.S. Geological Survey Techniques and Methods 10-C1, 27 p.

Révész, Kinga, and Coplen, T.B., 2008b, Determination of the $\delta(180 / 160)$ of water: RSIL lab code 489 , chap. C2 of Révész, Kinga, and Coplen, T.B., eds., Methods of the Reston Stable Isotope Laboratory: U.S. Geological Survey Techniques and Methods, 10-C2, 28 p.

Reynolds, J.M., 1997, An introduction to applied and environmental geophysics: Chichester, England, John Wiley \& Sons, 796 p.

Robbins, S.L., and Oliver, H.W., 1970, On making inner-zone terrain corrections to gravity data: U.S. Geological Survey report, Menlo Park, California, Internal Report 13 p., 2 pls.

Roberts, C.R., and Jachens, R.C., 1999, Preliminary aeromagnetic anomaly map of California: U.S. Geological Survey Open-File Report 99-440, 14 p. 
Roberts, C.W., Jachens, R.C., and Oliver, H.W., 1990, Isostatic residual gravity map of California and offshore southern California: California Division of Mines and Geology California Geologic Data Map Series, Map 7, scale 1:750,000.

Saltus, R.W., and Jachens, R.C., 1995, Gravity and basin depth maps for the Basin and Range Province, western United States: U.S. Geological Survey Geophysical Map GP-1012, scale $1: 2,500,000$.

Struzeski, T.M., DeGiacomo, W.J., and Zayhowski, E.J., 1996, Methods of analysis by the U.S. Geological Survey National Water Quality Laboratory-Determination of dissolved aluminum and boron in water by inductively compled plasmaatomic emission spectrometry: U.S. Geological Survey Open-File Report 96-149, 17 p., Method ID: I-1472-95.

Telford, W.M., Geldart, L.P., and Sheriff, R.E., 1990, Applied Geophysics (2nd ed.): New York, N.Y., Cambridge University Press, 770 p.

Thompson, D.G., 1929, The Mojave Desert region, California, a geographic, geologic, and hydrologic reconnaissance: U.S. Geological Survey Water-Supply Paper 578, 759 p.

U.S. Environmental Protection Agency, 2005, List of contaminants and their MCLs: U.S. Environmental Protection Agency data accessed on July 14, 2005, at http://water.epa. gov/drink/contaminants/index.cfm.

U.S. Environmental Protection Agency, Environmental Geophysics, 2011, Seismic reflection methods, accessed July 2012, at http://www.epa.gov/esd/cmb/GeophysicsWebsite/ pages/reference/methods/Surface_Geophysical_Methods/ Seismic_Methods/Seismic_Reflection_Methods.htm.

U.S. Geological Survey, variously dated, Collection of water samples (ver. 2.0): U.S. Geological Survey Techniques of Water-Resources Investigations, book 9, chap. A4, September 2006, accessed May 2011 at http://pubs.water. usgs.gov/twri9A4/.

Ward, A.W., Dixon, G.L., and Jachens, R.C., 1993, Geologic setting of the East Antelope Basin, with emphasis on fissuring on Rogers Lake, Edwards AFB, Mojave Desert, California: U.S. Geological Survey Open-File Report 93-263, 9p.

Western Regional Climate Center, Desert Research Institute, 2011a, Period of record general climate summary - Precipitation, Palmdale California, 1931-2005: accessed May 2011, at http://www.wrcc.dri.edu/cgi-bin/cliMAIN. pl? caplmd + sca.

Western Regional Climate Center, Desert Research Institute, 2011b, Period of record general climate summary - Precipitation, Pine Canyon, California, 1949-72: accessed May 2011, at http://www.wrcc.dri.edu/cgi-bin/cliMAIN. pl?ca6891.
Western Regional Climate Center, Desert Research Institute, 2011c, Period of record general climate summaryPrecipitation, Vincent Fire STN FC120 California, 19272003: accessed May 2011, at http://www.wrcc.dri.edu/ cgi-bin/cliMAIN.pl?ca9345.

Wilde, F.D., ed., variously dated, Field measurements: U.S. Geological Survey Techniques of Water-Resources Investigations, book 9, chap. A6, sec. 6.0-6.8, accessed May 2009, at http://pubs.water.usgs.gov/twri9A6/.

Zhang, J., Mackie, R.L., and Madden, T.R., 1995, 3-D resistivity forward modeling and inversion using conjugate gradients: Geophysics, v. 60, no. 5, p. 1313-1325. 
Prepared by the Sacramento Publishing Service Center.

For more information concerning this report, contact:

Director

U.S. Geological Survey

California Water Science Center

6000 J Street, Placer Hall

Sacramento, CA 95829

or visit our Web site at:

http://ca.water.usgs.gov 


\section{$\frac{\mathbb{2}}{3}$}

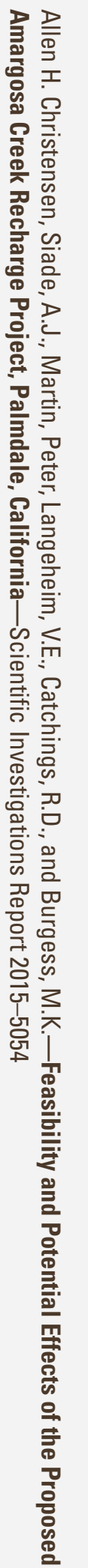

